Halinna Dornelles Wawruk

Estudo da expressão temporal e espacial de FoxN1 em modelos biológicos, durante o desenvolvimento embrionário e em jovens adultos 
UNIVERSIDADE DE BRASÍLIA

INSTITUTO DE CIÊNCIAS BIOLÓGICAS

DEPARTAMENTO DE BIOLOGIA ANIMAL

PROGRAMA DE PÓS-GRADUAÇÃO EM BIOLOGIA ANIMAL

\author{
HALINNA DORNELLES WAWRUK
}

Estudo da expressão temporal e espacial de FoxN1 em modelos biológicos, durante o desenvolvimento embrionário e em jovens adultos

Dissertação apresentada como requisito parcial para a obtenção do Título de Mestre em Biologia Animal, pelo Programa de Pós-Graduação em Biologia Animal, da Universidade de Brasília (UnB).

Orientadora: Dra. Aline Pic-Taylor.

Brasília, 
UNIVERSIDADE DE BRASÍLIA, BRASÍLIA

HALINNA DORNELLES WAWRUK

\section{Estudo da expressão temporal e espacial de FoxN1 em modelos biológicos, durante o desenvolvimento embrionário e em jovens adultos}

Dissertação apresentada como requisito parcial para a obtenção do Título de Mestre em Biologia Animal, pelo Programa de Pós-Graduação em Biologia Animal, da Universidade de Brasília (UnB).

\section{BANCA EXAMINADORA}

Dra. Aline Pic-Taylor (Presidente)

Universidade de Brasília

Dra. Juliana Forte Mazzeu de Araújo

Universidade Católica de Brasília

Dra. Rosângela Vieira de Andrade

Universidade Católica de Brasília

Dra. Silviene Fabiana de Oliveira (Suplente)

Universidade de Brasília 


\section{AGRADECIMENTOS}

Primeiramente, gostaria de agradecer a Deus pela oportunidade de continuar meus estudos, sei que sempre sou abençoada por Ele e que Ele faz o melhor por mim.

Gostaria de agradecer também à minha orientadora, Dra. Aline Pic-Taylor, que eu diria ser minha "mãe acadêmica", por ter confiado em mim e por ter sido tão prestativa e gentil em todos os momentos durante esse mestrado. Aos doutores e professores César Koppe Grisólia, , Antônio Sebben, Márcia Mortari, Silviene F. de Oliveira, Daniela M. de Oliveira, Mônica P. Garcia, Sacha B. Chaves, Rosângela V. de Andrade, Juliana F. Mazzeu, Irene Yan, Mara S. Córdoba e José Eduardo Baroneza pela paciência em me ensinar os métodos necessários que vim a utilizar neste projeto.

Aos colegas de trabalho e pesquisa Willian, Juliana, Alana, Fred, Raphael, Mariana, Camila, Janaína e José Filho (hoje um anjo), que alegraram meus dias mais desesperadores e também os mais tranquilos.

Às minhas queridas estagiárias, Ana Paula (Aninha), Muriel (Muri) e Ana Carolina por todo o apoio moral, esforço físico, dedicação e que com muito bom humor me acompanharam ao longo deste projeto.

Aos funcionários e parceiros do Instituto de Biologia por todo o suporte nos trâmites burocráticos ao longo desse percurso, principalmente a técnica Zélia R. Madeira e Claudiner pelo apoio.

À empresa AsaAlimentos S/A pela doação de todos os ovos galados utilizados durante o mestrado, em especial, a funcionária Leydianne, que sempre me respondeu prontamente e gentil para mais uma doação.

Ao meu querido marido, Leonardo Bernardes Nogueira, que sempre esteve e está próximo a mim, sempre me incentivando a colher os frutos mais altos e me fazendo a mulher mais amada do mundo, eu te amo.

Aos meus pais, Maria Dornelles e Rubens Wawruk, que acima de todos, são responsáveis por eu conseguir chegar até onde cheguei, eu amo vocês.

A todos os meus familiares que estão em Brasília e em Curitiba, que mesmo longe, estão sempre perto.

Aos meus amigos, Alessandra (Broto), Clarissa, Jaqueline, Mariane, Alinne, Bárbara, Fernanda F., Marília e Rodrigo, por todo o suporte e pelas boas risadas. 
À Universidade de Brasília e à Universidade Católica de Brasília pelo apoio científico e ao CNPq, à FAP/DF, a CAPES pelo fomento dos estudos.

E a todos que contribuíram direta ou indiretamente para a realização desse estudo e para o meu desenvolvimento profissional e pessoal.

Obrigada. 
"Jumping from failure to failure with undiminished enthusiasm is the big secret of success."

(Savas Dimopoulos) 


\section{Resumo}

Nas últimas décadas, houve um avanço significativo na compreensão dos mecanismos moleculares que permitem o entendimento da origem e do desenvolvimento de um organismo desde a fertilização até a forma adulta. A comparação de genomas de organismos modelo, tais como, Drosophila melanogaster (mosca da fruta), Caenorhabditis elegans (nematódeo), Danio rerio (zebrafish), Xenopus laevis (rã africana), Gallus gallus (galinha) e Mus musculus (camundongo), contribuíram para a identificação de famílias de genes altamente conservadas que regulam o desenvolvimento permitindo um melhor esclarecimento dos processos evolutivos que deram origem a estes animais e a outros. A família de genes forkhead é um exemplo relevante de família gênica conservada evolutivamente e codifica produtos funcionais importantes para uma série de processos biológicos essenciais, como a regulação do ciclo celular e do metabolismo e da organogênese. O estudo aqui apresentado teve como objetivo explorar, por meio do estudo da expressão temporal e espacial em organismo modelo (G. gallus), a hipótese de que o gene FoxN1, um membro da família forkhead, participa no desenvolvimento do sistema nervoso central (SNC). Além disso, identificamos um paciente com uma deleção em heterozigoze em $F O X N 1$ que apresentava fenótipo sindrômico, pelo uso da técnica de Cromossomal Microarray (CMA). Os dados apresentados mostraram que a proteína FoxN1 tem grande similaridade evolutiva em sequência de nucleotídeos e em sequência de aminoácidos e que apresenta os domínios forkhead e de ativação como sequencias bem conservadas, além de ter FoxN4 como proteína homóloga. Estudos em camundongos Nude não confirmaram a localização da proteína Foxn1 no plexo coróide. Cérebros de camundongos do tipos selvagem $($ Foxn1 $+/+$ ), heterozigoto (Nude/+) e Nude (Foxn1 -/-), mostraram-se estruturalmente similares, sem o comprometimento da formação do plexo coróide ou dos ventrículos. Estudos de expressão de FoxN1 em embriões de G. gallus, mostraram uma expressão crescente nos primeiros estágios do desenvolvimento, coincidentes com a formação de estruturas primordiais do SNC. Em adição, dados preliminares de imunofluorescência mostrou que houve expressão de FoxN1 na região dos arcos faríngeos. $\mathrm{O}$ paciente estudado, apresentava malformação cefálica e facial e era portador de uma deleção dos primeiros éxons de $F O X N 1$ em heterozigose. Estes achados fortalecem a hipótese de uma função de FoxN1 no desenvolvimento do SNC.

Palavras chave: FoxN1, organismos modelo, qPCR, expressão gênica, imunofluorescência, Sistema Nervoso Central, deleção, Microarranjo Cromossômico. 


\begin{abstract}
In the last few decades, significative progress was made in the understanding of molecular mechanisms that allow origin and development of an organism from fertilization to adulthood. Futhermore, the comparison of genomes of model organisms, such as Drosophila melanogaster (fruitfly), Caenorhabditis elegans (nematode worm), Danio rerio (zebrafish), Xenopus laevis (South Africa frog) Gallus gallus (chicken) e Mus musculus (mouse), contributed to the identification of highly conserved gene families which regulates the development, allowing better understanding of evolutionary processes that gave rise to these animals e other related ones. The forkhead gene family is a relevant example of gene family conserved evolutionarily; that encodes important functional products which participate in a range of essential biological processes such as cell cycle regulation, metabolism and organogenesis. The study presented here aimed to explore, through the study of temporal and spatial expression in model organism (G. gallus) by in silico analysis of the gene, qPCR and immunofluorescence and; macroscopic comparison and microtomography images of $M$. musculus brains, the hypotesis of Amorosi and colleagues $(2008,2010)$ that FoxN1 gene, a member of the forkhead family, participates in the development of the central nervous system (CNS). In addition, we identified a patient with a heterozygous deletion in FOXN1 gene (by using Chromosomal microarray - CMA), which had a syndromic phenotype. The data presented here shows that the FoxN1 protein has great evolutionary similarity both in nucleotide and aminoacid sequence, with conserved forkhead and activation domains. In addition it has a homologous protein, FoxN4 that has arise by ancient duplication. Nude mice studies did not confirm the location of Foxn1 protein to the choroid plexus. In addition, brains of wild type (Foxn1 +/+), heterozygous $(\mathrm{Nude} /+)$ and Nude (Foxn1 -/-), proved structurally similar. Expression studies of FoxN1 in G. gallus embryos showed increased expression in the early stages of development, which coincides with the formation of primary CNS structures. In addition, the immunofluorescence studies showed FoxN1 expression in the pharygeal arches region. However, these results are preliminary and need to be confirmed. The patient studied showed a head and face malformations and carry a deletion of the firsts exons of FOXN1 in condition of heterozygosis. These findings strengthen the hypotesis of a Foxn1 role in CNS development.
\end{abstract}

Key words: FoxN1, model organisms, qPCR, gene expression, immunofluorescence, Central Nervous System, deletion, Chromosomal Microarray. 


\section{SUMÁRIO}

1. INTRODUÇÃO 1

2. REVISÃO BIBLIOGRÁFICA 2

2.1. Histórico da caracterização das proteínas forkhead. 2

2.2. Estrutura do domínio forkhead. 3

2.3. Sítio de ligação das proteínas forkhead ao DNA. 5

2.4. Evolução das proteínas forkhead (Fox). 5

2.5. Funções das proteínas Fox. 10

2.6. Estrutura da proteína FoxN1. 11

2.7. Funções de FoxN1. 14

2.8. FoxN1 e o desenvolvimento do Sistema Nervoso Central. 17

2.9. Desenvolvimento inicial do Sistema Nervoso Central. 22

2.10. Estudos com organismos modelo na embriologia. 25

3. OBJETIVO 28

3.1. Objetivo Geral 28

3.2. Objetivos Específicos 28

4. MATERIAL E MÉTODOS 29

4.1. Animais 29

4.2. Paciente 30

$\begin{array}{lll}4.3 & \text { Métodos } & 30\end{array}$

4.3.1. Estudo in silico dos produtos do gene FoxN1 em G. gallus. 30

4.3.2 Coleta dos embriões de G. gallus. 31

4.3.3. Extração de RNA.

4.3.4. Preparo do cDNA total. 33

4.3.5. qPCR. 34

4.3.6. Imunofluorescência de embriões de G. gallus. 34

4.3.7. Coleta dos cérebros de camundongos. 35

4.3.8. Microtomografias. 35

4.3.9. Extração de DNA de sangue do paciente e análise cromossômica por Chromosomal Microarray (CMA). 36 
4.3.10. Análise estatística dos dados obtidos.

5. RESULTADOS 38

5.1. Análise in silico de FoxN1. 38

5.2. Análise da qPCR em G. gallus. 44

5.3. Imunofluorescência dos embriões de G. gallus. 48

5.4. Comparação anatômica e por microtomografia de cérebros de M. musculus (C57BL/6).

5.5. Análise do paciente heterozigoto para FOXN1. 56

6. DISCUSSÃO 60

7. CONCLUSÕES 64

8. REFERÊNCIAS BIBLIOGRÁFICAS 65

9. ANEXOS 74

9.1. Anexo 1: Sequência nucleotídica do domínio forkhead de M. musculus. 74

9.2. Anexo 2: Certificados com parecer aprovado pelo CEUA-UnB. 75

9.3. Anexo 3: Termo de Consentimento Livre e Esclarecido. 77 


\section{LISTA DE FIGURAS}

Figura 1. Representação esquemática do domínio forkhead da proteína FREAC-11 (proteína forkhead humana) desenhada a partir dos estudos por RNM de Van Dongen et

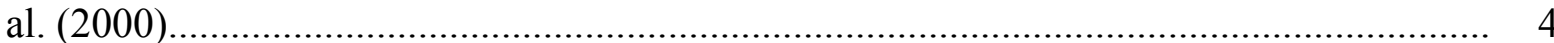

Figura 2. Estrutura tridimensional do domínio de ligação de Foxa2 ao DNA..................... 5

Figura 3. Filogenia das proteínas Fox em cordados baseado na sequência de aminoácidos

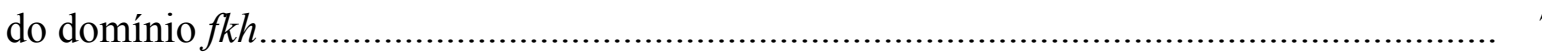

Figura 4. Alinhamento dos genes Fox em camundongos.............................................. 9

Figura 5. Representação esquemática do fator de transcrição Foxn1 de camundongo........ 12

Figura 6. Representação do domínio forkhead $(f k h)$ de FoxN1 .......................................... 12

Figura 7. Representação da estrutura do gene FOXN1 em H. sapiens................................ 12

Figura 8. Comparação da sequência de aminoácidos da proteína FOXN1 em humanos, camundongos e ratos

Figura 9. Padrão de expressão de Foxn1 durante o desenvolvimento embrionário de camundongos

Figura 10. Organogênese do timo 16

Figura 11. Diferenças na pele e pelos entre camundongo controle e nude (Foxn1 -/-)........ 17

Figura 12. Fenótipo morfológico de um feto humano FOXN1 -/-

Figura 13. Secções cerebrais do feto homozigoto recessivo para FOXN1. 20

Figura 14. Expressão de Foxn1 em cérebro de embriões de camundongos.

Figura 15. Esquemas de cortes transversais através de embriões progressivamente mais velhos ilustrando a formação do tubo neural

Figura 16. Desenho que representa etapas de desenvolvimento de alguns animais, sendo eles o peixe, a salamandra, a tartaruga, o porco, o vitelo, o coelho e o ser humano.

Figura 17. Modelo de preparação de papel de filtro utilizado para coleta de embriões de galinha com período de incubação inferior a 3 dias. 
Figura 18. Representação da estrutura da proteína e do gene FoxN1 de G. gallus respectivamente.

Figura 19. Diagrama construído por meio do software TMHMM (http://www.cbs.dtu.dk/services/TMHMM/) que mostra a estrutura da sequência de resíduos de aminoácidos de FoxN1 de G. gallus (NCBI XP_415816.4)....

Figura 20. Diagrama de hidrofobicidade da proteína FoxN1 de G. gallus segundo a escala de Kyte-Doollitle (http://gcat.davidson.edu/DGPB/kd/kyte-doolittle.htm).....

Figura 21. Resultado do alinhamento - feito pelo software Jalview - das sequências de aminoácidos de FoxN1 das espécies H. sapiens (gi: 18201913), G. gorilla (gi: 426348868), Macaca mulatta (gi: 109113734), M. musculus (gi: 148683621), R. norvergicus (gi: 154816166), G. gallus (gi: 513215825) e D. Rerio (gi: 47086885).....

Figura 22. Resultado do alinhamento - feito pelo software Jalview - das sequências de aminoácidos de FoxN1 das espécies H. sapiens (gi: 18201913), G. gorilla (gi: 426348868), Macaca mulatta (gi: 109113734), M. musculus (gi: 148683621), R. norvergicus (gi: 154816166), G. gallus (gi: 513215825) e D. Rerio (gi: 47086885).

Figura 23. Alinhamento das sequências de aminoácidos das proteínas da subclasse Fox encontradas na espécie G. gallus feito pelo software Jalview.

Figura 24. Alinhamento das sequências de aminoácidos das proteínas da subclasse FoxN encontradas na espécie G. gallus feito pelo software Jalview.

Figura 25. Árvore filogenética baseada nas sequências de aminoácidos das proteínas Fox de G. gallus construída com auxílio do software CLUSTALW.

Figura 26. Imagens de embriões de galinha em diferentes estágios, sendo A, HH 4 (18 h); B, HH 6 (24 h); C, HH 10 (33 h); D, HH 12 (48 h), E, HH 17 (60 h); F, HH 20 (72 h); G, HH 24 (4 dias); H, HH 27 (5 dias); I, HH 29 (6 dias) e J, HH 31 (7 dias).................

Figura 27. Análise da expressão de FoxN1 nos estágios de desenvolvimento de G. gallus.

Figura 28. Análise da expressão de FoxN1 nos órgãos coletados de recém-nascidos, 21 dias, sendo eles o cérebro, o coração, o músculo peitoral e o timo.

Figura 29. Alinhamento das sequencias de FoxN1 e de FoxN4 de G. gallus com a predita região do epítopo do anticorpo FOXN1 G-20 (Santa Cruz Biotechnologies, Inc. feita utilizando a sequência de FOXN1 humano como modelo base. 
Figura 30. Imagens de imunofluorescência de um embrião de 48 h (HH 12), a e b, em aumento, e imagem de fase do mesmo embrião...

Figura 31. Esquema representando um embrião HH 12 (48 h) com algumas estruturas apontadas

Figura 32. Gráfico da razão peso do órgão/peso do corpo de cada grupo em referencia aos órgãos: cérebro, coração, fígado, pulmão, rins e baço.

Figura 33. Fotografias dos cérebros coletados dos camundongos.

Figura 34. Fotomicrografia do cérebro de um dos camundongos selvagens.

Figura 35. Fotomicrografia do cérebro de um dos camundongos Nude/+ 55

Figura 36. Fotomicrografia do cérebro de um dos camundongos Nude.

Figura 37. Fotografias tiradas do paciente com deleção parcial de FOXN1 em heterozigose

Figura 38. Imagem mostra uma representação do cromossomo 17 humano......

Figura 39. Alinhamento de parte da sequência deletada no cromossomo 17 do paciente heterozigoto para $F O X N 1$ com a sequência do gene em questão.

Figura 40. Representação da estrutura do gene FOXN1 na espécie humana 


\section{LISTA DE TABELAS}

Tabela 1. Comparação das dimensões dos cérebros coletados dos três grupos de camundongos... 
DNA - Ácido desoxirribonucleico.

fkh-Forkhead.

HNF-3 - Hepatocyte Nuclear Factor 3.

TTR - gene transthyretin.

RNM - Ressonância nuclear magnética.

Fox - Proteínas/genes da família forkhead.

an - Ácidos nucléicos.

aa - Aminoácidos.

NCBI - National Center for Biotechnology Information.

3D - Tridimensional.

cDNA - Ácido desoxirribonucleico complementar.

SCID - Síndrome da Imunodeficiência Combinada Severa.

CET - Células epiteliais do timo primordial.

Nude - Nome atribuído ao fenótipo de camundongos homozigotos recessivos para Foxn1.

H\&E - Hematoxilina e Eosina.

RNAm - Ácido ribonucleico mensageiro.

SNC - Sistema Nervoso Central.

DTN - Defeitos do Tubo Neural.

PC - Plexo coróide.

LCR - Líquido cefalorraquidiano.

Hox - Proteínas da família Homeobox.

qPCR - Reação em cadeia polimerase em tempo real.

RNA - Ácido ribonucleico.

HUB - Hospital Universitário de Brasília.

UnB - Universidade de Brasília.

DEPC - Dietilpirocarbonato.

CEUA - Comitê de Ética do Uso Animal.

S/A - Sociedade Anônima.

GEM - Departamento de Genética e Morfologia. 
LTDA - Limitada.

FAP-DF - Fundação de Amparo à Pesquisa do Distrito Federal.

RPM - Rotações por minuto.

Inc. - Incorporated.

$\mathrm{ng}$ - nanogramas, fração que corresponde a $10^{-9} \mathrm{~g}$.

$\mathrm{pb}$ - pares de bases nitrogenadas. 


\section{INTRODUÇÃO}

Nas ultimas décadas, houve um avanço significativo na compreensão dos mecanismos moleculares que permitiram o entendimento da origem e do desenvolvimento de um organismo desde o ovo fertilizado até a sua forma adulta. O progresso tecnológico das áreas da biologia molecular, celular e genética, complementadas por estudos de modelos biológicos da embriologia clássica, permitiram hoje associações pontuais de eventos moleculares com as consequentes mudanças morfológicas durante a geração de um novo ser (Wolpert, 2000; Gilbert, 2003).

Além disso, a comparação de genomas de organismos modelo, tais como, o da mosca da fruta Drosophila melanogaster, do nematódio Caenorhabditis elegans, do peixe Danio rerio, do anfíbio Xenopus laevis, da ave Gallus gallus e do mamífero Mus musculus, contribuiu para identificação de famílias de genes altamente conservadas que regulam o desenvolvimento destes organismos, permitindo um melhor esclarecimento dos processos evolutivos que deram origem a estes animais e a outros relacionados a eles.

A família de genes forkhead é um exemplo relevante de família gênica conservada ao longo da evolução e que codifica produtos funcionais importantes não somente para o desenvolvimento embrionário, desde a correta formação do embrião bilaminar (foxh1), mas também seus produtos gênicos participam, no adulto, de processos primordiais específicos como controle do metabolismo da glicose (subclasse FoxO), controle do ciclo celular (FOXG1) e outros. A investigação do padrão de expressão gênica de membros da família forkhead em organismos modelo auxilia na compreensão dos mecanismos embriológicos nos quais estas proteínas estão inseridas, bem como dos processos evolutivos que deram origem à multifuncionalidade desta importante família de fatores de transcrição. Estes estudos contribuem também para o nosso entendimento das possíveis funções tecido-especificas destes genes em indivíduos adultos.

O trabalho aqui apresentado visou explorar, por meio do estudo da expressão temporal e espacial em organismo modelo (Gallus gallus), a hipótese recente de Amorosi e colaboradores $(2008,2010)$ de que o gene FoxN1, um membro da família forkhead, pode ter um papel no desenvolvimento do sistema nervoso central (SNC). Além do mais, ao longo do projeto, por meio da colaboração com o Laboratório de Citogenética Clínica, da Faculdade de Saúde da Universidade de Brasília (FS-UnB), foi identificado um paciente com uma deleção em heterozigoze em FOXN1, pelo uso da técnica de Chromossomal Microarray (CMA), que apresentava fenótipo sindrômico sendo também descrito nesta dissertação. 


\section{REVISÃO BIBLIOGRAFICA}

\subsection{Histórico da caracterização das proteínas forkhead}

As proteínas forkhead são parte de uma extensa família de fatores de transcrição funcionalmente diversos que estão envolvidos em uma variedade de processos biológicos (Coffer e Burgering, 2004), tais como o controle do ciclo celular (Pic et al., 2000), a diferenciação celular (Acilli e Arden, 2004), o desenvolvimento da linguagem (Lai et al., 2001), e também eventos da embriogênese e desenvolvimento, incluindo a formação do sistema nervoso central (SNC) (Hebert e McConnell, 2000).

Os fatores de transcrição, por sua vez, são proteínas modulares que através da ligação ao DNA, agem na trans-ativação ou trans-repressão (Carlsson e Mahlapuu, 2002) de um gene. Eles são, na maioria das vezes, classificados de acordo com o domínio estrutural envolvido na ligação ao DNA ou, em alguns casos, de acordo com seu domínio de oligomerização (Kaufmann e Knochel, 1996).

O domínio de ligação ao DNA tende a ser particularmente bastante conservado e pode, por isso, ser usado como a base para classificação. Fatores de transcrição que apresentam um mesmo desenho básico nesse domínio também tendem a ter funções similares e a compartilhar propriedades (Carlsson e Mahlapuu, 2002).

O nome forkhead deriva de dois produtos fundadores dessa família: o produto do gene forkhead $(f k h)$ de D. melanogaster e uma pequena família de fatores de transcrição em roedores, a família HNF-3 (Hepatocyte Nuclear Factor - 3), hoje conhecida como FoxA3 (Lai et al., 1990). O produto do gene forkhead participa no desenvolvimento de estruturas mais cefálicas do intestino primitivo no embrião da mosca da fruta (D. melanogaster) e foi visto que uma mutação simples neste gene ocasiona um defeito que prejudica a involução da dobra cefálica, resultando no surgimento de um tecido que lembra o desenho de um garfo nessa região, daí vindo o nome forkhead (do inglês fork $=$ garfo e head $=$ cabeça) (Hannenhalli e Kaestner, 2009). Logo depois dessa descoberta, um novo grupo de fatores de transcrição específicos para o fígado foi identificado em roedores $(H N F-3)$ e estes apresentavam um domínio de ligação ao DNA com alta similaridade em relação àquele do produto do gene $f k h$ (Lai et al., 1990).

Essa família é caracterizada pela presença de uma sequência de 110 resíduos de aminoácidos, o qual compreende seu domínio de ligação ao DNA. Esse domínio, conhecido como forkhead/HNF-3 foi, mais tarde, encontrado dentro de muitas proteínas em diferentes 
espécies indo desde leveduras (Saccharomyces cerevisiae, Schizossacharomyces pombe) (Pic et al., 2000; Bulmer et al., 2004) até os seres humanos (Lai et al., 1993) e está presente somente em eucariotos. Até o presente momento não foram encontrados fatores de transcrição do tipo forkhead em plantas (Mazet et al., 2003).

\subsection{Estrutura do domínio forkhead}

A estrutura do domínio forkhead foi descrita por análise de cristalografia por raios-X usando o domínio forkhead de $H N F-3 \gamma$ ligado a seu elemento no DNA (Clark et al., 1993). O sítio alvo desse elemento incluía 11 resíduos da região promotora 5' do gene transthyretin (TTR) (Kaufmann e Knochel, 1996). Mais tarde, em 1998 (Marsden et al., 1998), um estudo com ressonância nuclear magnética (RNM) estendeu os resultados obtidos anteriormente. Um grupo de quatro $\alpha$-hélices (H1, H2, H3 e H4) é encontrado na extremidade N-terminal do domínio e forma um domínio globular com um centro hidrofóbico (Marsden et al., 1998; Van Dongen et al., 2000) e existem duas regiões do tipo não ordenadas, que formam estruturas frouxas aparentando o formato de "asas", do inglês wing-like structures, W1 e W2 estão localizadas na extremidade C-terminal do domínio (Marsden et al., 1998; Van Dongen et al., 2000). Também há três fitas- $\beta$ ( $\beta$-strand: S1, S2 e S3) no domínio dispostas da seguinte maneira: S1 está localizada entre H1 e H2; e S2 e S3 estão separadas por W1, localizado atrás de H3. Todas as três folhas- $\beta$ juntas formam uma única folha- $\beta$ com três filamentos simples, torcida e antiparalela que se mostra contra o DNA (Marsden et al., 1998; Van Dongen et al., 2000). Finalmente, W2 está localizado atrás de S3, na extremidade C-terminal do domínio forkhead. (Figura 1). O domínio forkhead liga-se ao DNA como um monômero, conectandose à sua sequencia alvo pela terceira $\alpha$-hélice, por resíduos flanqueadores e pelas duas asas (Hannenhalli e Kaestner, 2009) e adota uma estrutura compacta na qual as extremidades Cterminal e N-terminal estão situadas em faces opostas da molécula (Fig. 1) (Van Dongen et al., 2000).

A ligação coordenada de íons de magnésio fortalece a associação de H3 e S2, e parece ser essencial para o correto dobramento do domínio (Clevidence et al., 1993; Hacker et al., 1995). Além disso, a ligação ao DNA é completamente interrompida quando há mutação em aminoácidos relacionados com a coordenação de magnésio (Hacker et al., 1995). 


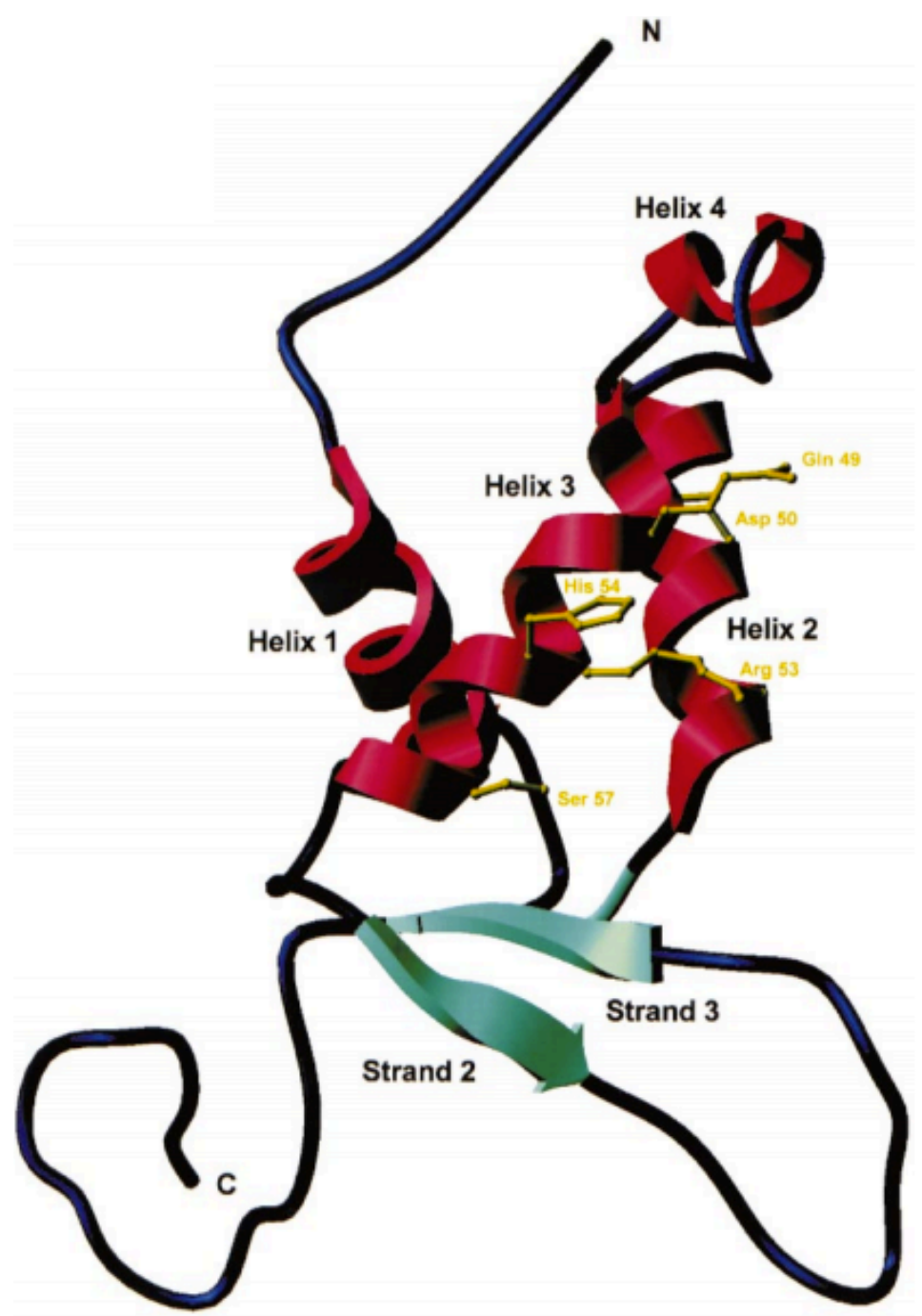

Figura 1. Representação esquemática do domínio forkhead da proteína FREAC-11 (proteína forkhead humana) desenhada a partir dos estudos por RNM de Van Dongen et al. (2000). As quatro $\alpha$-hélices (H1-H4) estão mostradas em vermelho e as três folhas- $\beta$ (S1-S3), em verde. S1 é pouco visível na imagem e está atrás de S3. As duas regiões não ordenadas do tipo wing-like W1 e W2 estão localizadas na extremidade C-terminal desse domínio. Os resíduos envolvidos na ligação ao DNA são mostrados em amarelo.

A estrutura tridimensional do domínio forkhead, por causa das estruturas W1 e W2, que abraçam o DNA quando o domínio se liga a ele, também lembra as asas de uma borboleta, por esse motivo, são também conhecidas como proteínas aladas (winged-helix proteins). (Clark et al., 1993). 


\subsection{Sítio de ligação das proteínas forkhead ao DNA}

Estudos feitos na década de 1990, por Clark e colaboradores (1993) e Pierrou e colaboradores (1994) mostraram que as proteínas forkhead ligam-se ao DNA em uma sequência consenso identificada em pelo menos três proteínas que consiste de um motivo central de reconhecimento. Esse motivo, 5' [(G/A) (T/C) (C/A) A A (C/T) A] 3' é conhecido por entrar em contato com a $\alpha$-hélice de reconhecimento, H3 (Figura 2). É possível que exista um motivo maior descrito por Kaufmann e Knochel (1996), que compreende 5' [(A/T) (A/G) A (G/A) (T/C) (C/A) A A (C/T) A] 3'. Porém, é importante lembrar que a especificidade da ligação de cada proteína depende da diversidade das sequências 5' e 3' flanqueando esse motivo central (Pic et al., 2000).

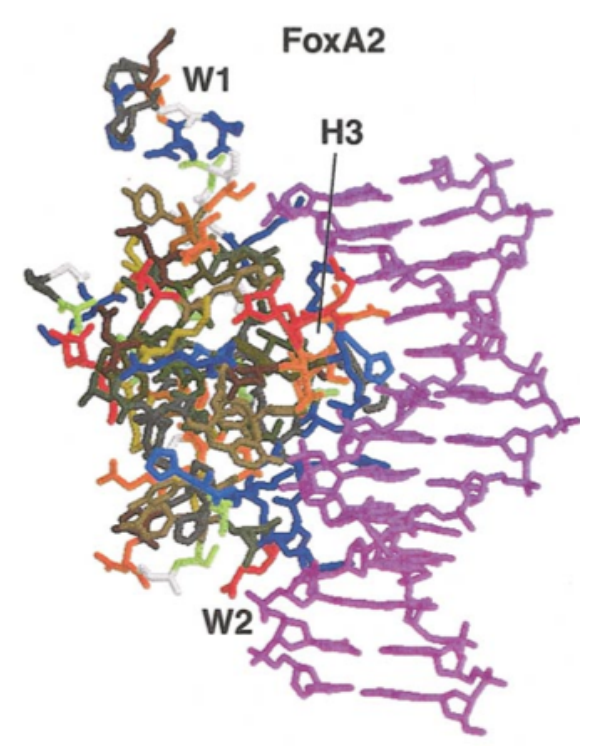

Figura 2. Estrutura tridimensional do domínio de ligação de Foxa2 ao DNA. A estrutura FoxA2 mostra a hélice de reconhecimento (H3) preenchendo o sulco maior do DNA. A primeira asa, W1 chega ascendente, aproximadamente paralela com o eixo helicoidal do DNA e além da extremidade 3' do oligonucleotídeo, enquanto a segunda asa, W2, faz o sulco menor entrar em contato com a extremidade 5' do sítio de ligação Figura retirada do artigo Carlsson e Mahlapuu (2004).

\subsection{Evolução das proteínas forkhead (Fox)}

A característica que une todas as proteínas Fox é o domínio de ligação ao DNA, o domínio forkhead já citado. Esse domínio é altamente conservado através de todos os 
membros da família Fox. Por meio de sequências de aminoácidos depositada nos bancos de dados proteômicos internacionais foi possível desenhar uma árvore filogenética relacionando as proteínas Fox que aparecem em várias espécies como Homo sapiens, G. gallus, X. laevis, D. melanogaster, M. musculus, Rattus norvergicus, D. rerio, Cynops orientalis, Oryzias latipe e outros (Kaestner et al., 2000) (Figura 3).

A filogenia é próxima para todos os cordados. Hannenhalli e Kaestner (2009) fizeram uma revisão sobre a evolução das proteínas Fox e mostraram o alinhamento destas presentes em M. musculus que inclui uma sequência consenso presente em todas representantes do grupo Fox, como se pode verificar na Figura 4.

A similaridade entre as proteínas Fox de seres humanos e camundongos varia entre 48 $\%($ FOXN2) até 99,7 \% (FOXB1 e FOXP2). FOXN1 mostra 90,9 \% de similaridade entre essas espécies (Jackson et al., 2010).

De acordo com dados retirados do sítio GeneCard, FOXN1 é conservado evolutivamente e existem pelo menos 17 ortólogos para ele incluindo, entre outras, as seguintes espécies: Pan troglodytes (chimpanzé) com similaridade ao gene/proteína humana de 99,13\% (para ácidos nucléicos - an) e 98,15\% (para aminoácidos - aa); R. norvergicus (rato) com similaridade de 83,97\% (an) e 85,59\% (aa); G. gallus (galinha) com similaridade de $64,27 \%$ (an) e $57,91 \%$ (aa); D. rerio (zebrafish) com similaridade de 57,81\% (an) e $53,66 \%$ (aa). 


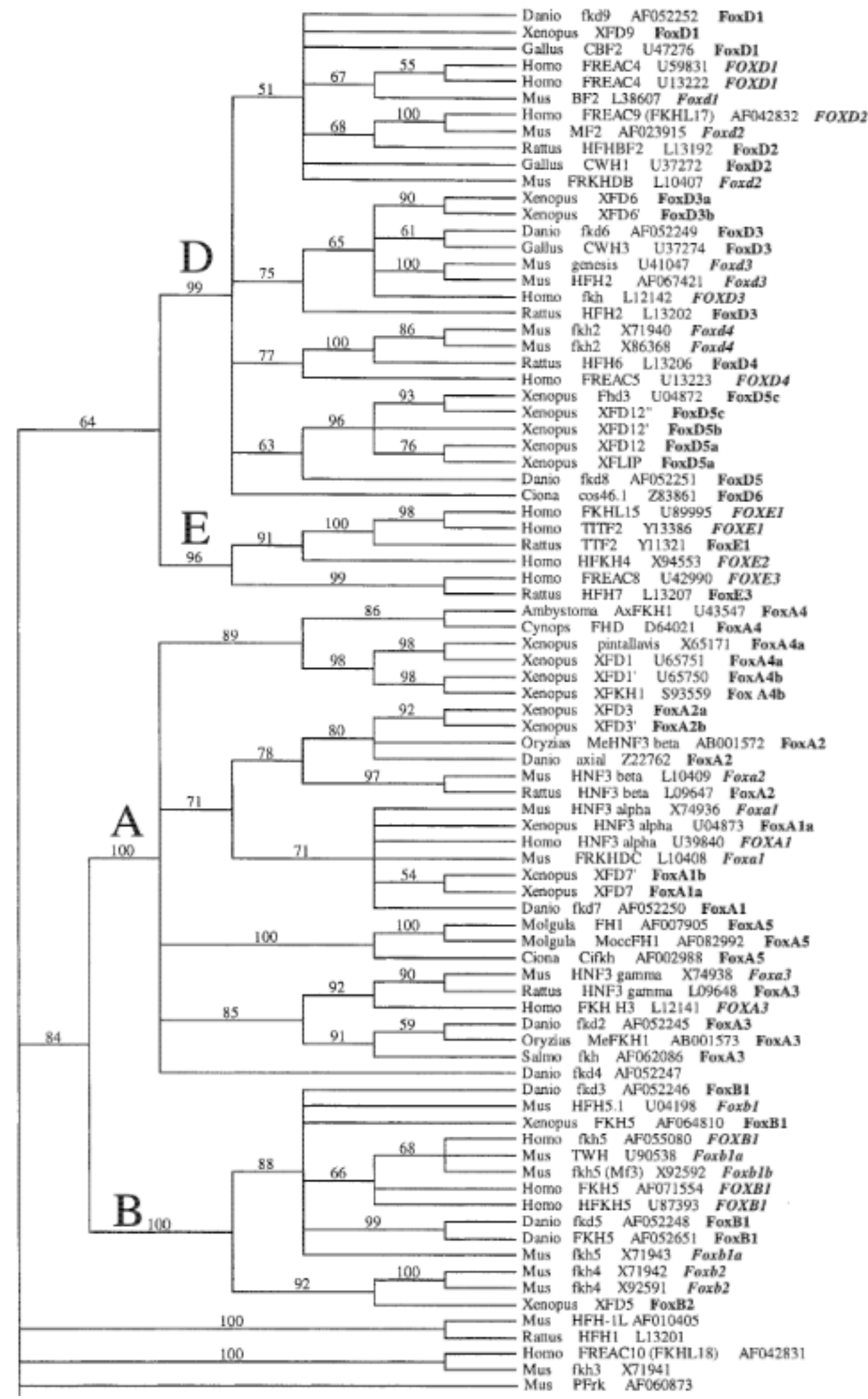

Figura 3. Filogenia das proteínas Fox em cordados baseado na sequência de aminoácidos do domínio $f k h$. A árvore foi baseada usando Homo QRF1 (AF086040) como grupo externo. Os números no interior dos ramos representam porcentagens de início. Para cada proteína foram indicados o organismo (Gênero), o nome, número de acesso e nome Fox proposto. Figura retirada do artigo Kaestner et al. (2000). 


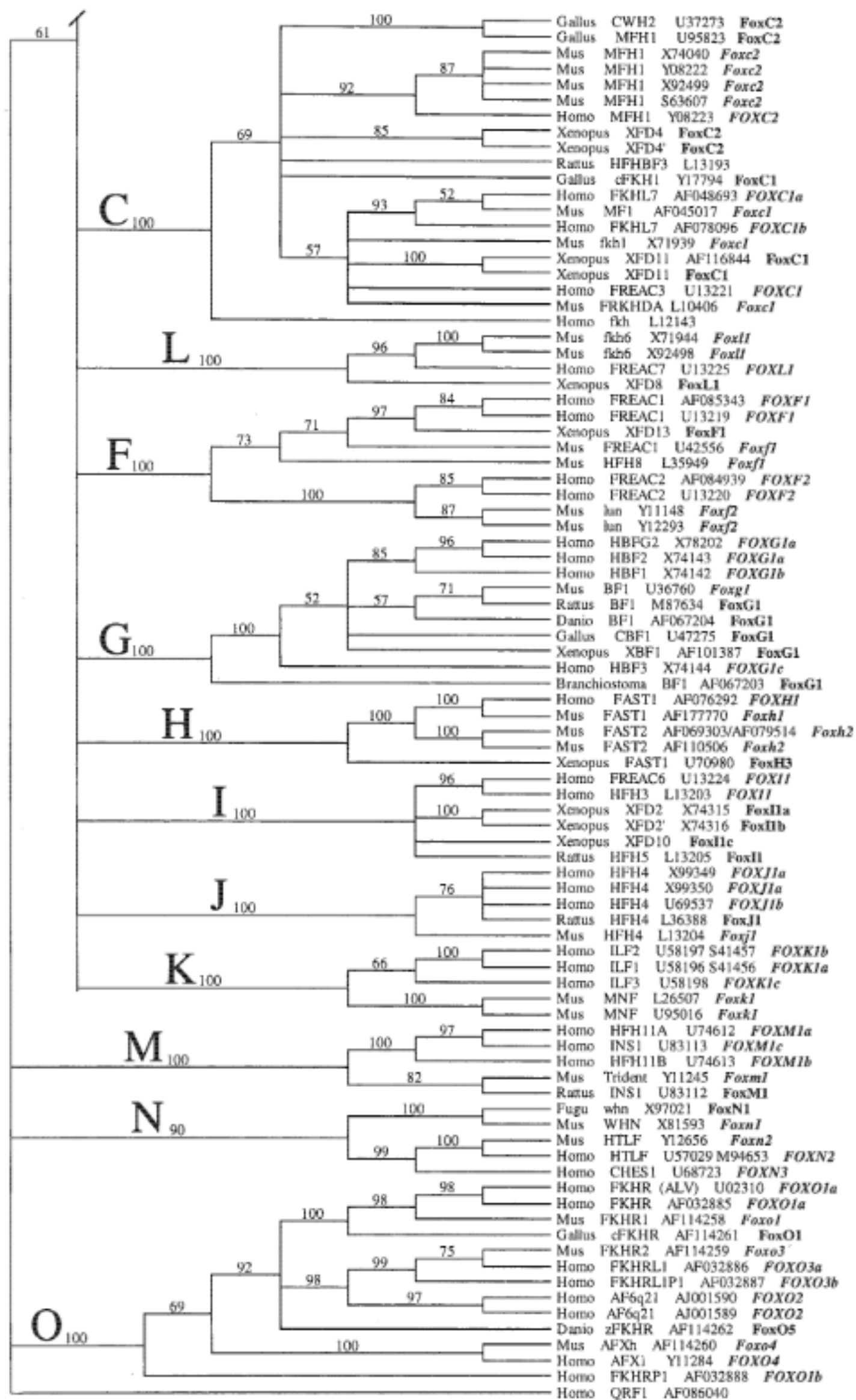

Figura 3. Continuação. 


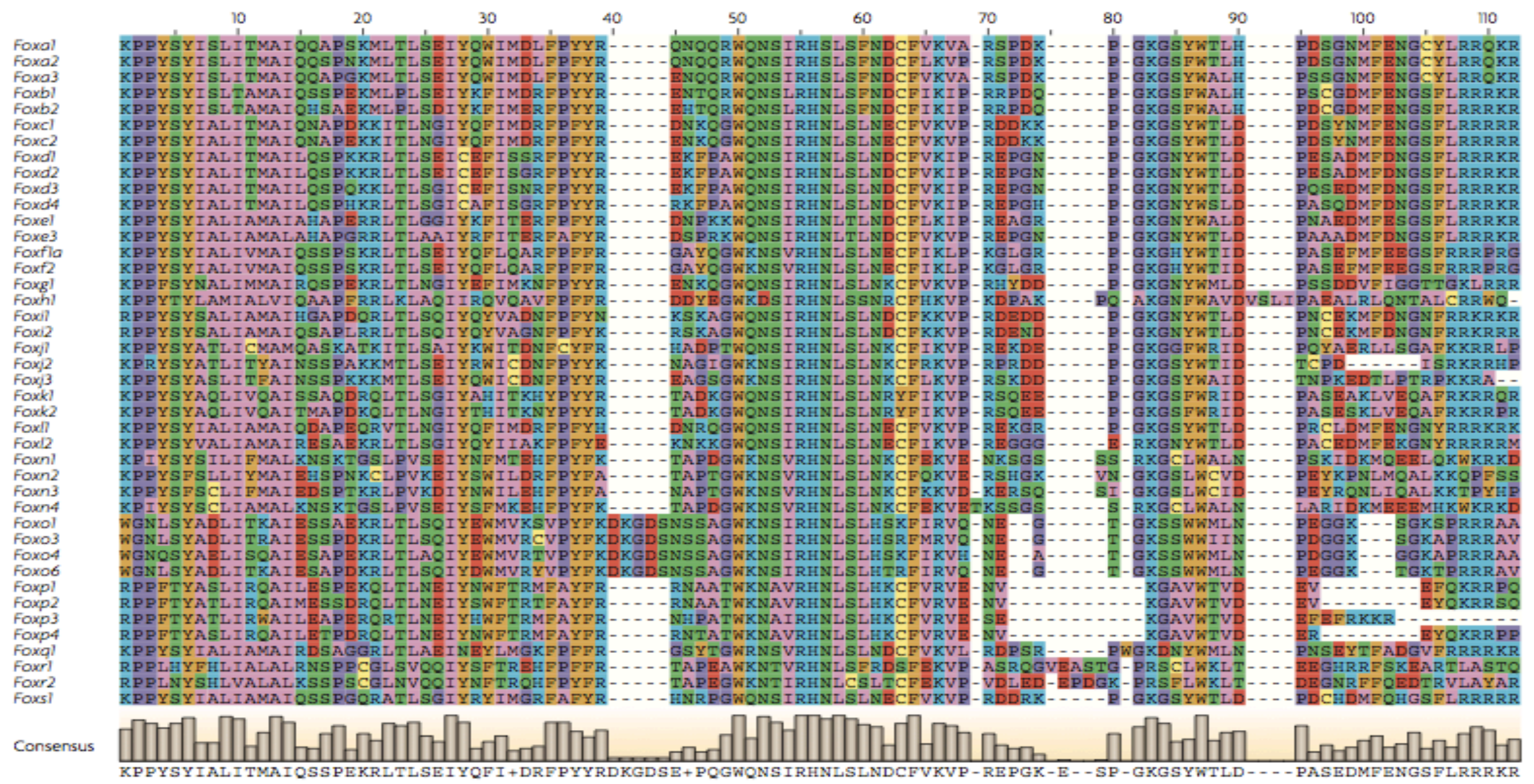

Figura 4. Alinhamento dos genes Fox em camundongos. Todas as sequencias de proteínas que contêm o domínio forkhead foram extraídas de ENSEMBL v50. As sequencias de proteínas foram alinhadas usando a ferramenta de múltiplo alinhamento T-Coffee. $\mathrm{O}$ alinhamento foi visualizado usando o editor de alinhamento Jalview. O painel abaixo mostra o domínio $f k h$ como mostrado no banco de dados Pfam. O domínio $f k h$ é a única porção conservada na proteína através de todos os membros da família, enquanto que existem similaridade em outras regiões entre as subfamílias Fox. O código de cor dos aminoácidos é baseado nas propriedades físico-químicas providas pelo programa Jalview. Figura retirada do artigo Hannenhalli e Kaestner (2009). 


\subsection{Funções das proteínas Fox}

Baseando-se nas similaridades do domínio forkhead $(f k h)$, as mais de 170 proteínas Fox foram inicialmente divididas (Jonsson e Peng, 2005) em 15 subclasses incluindo todas as proteínas Fox dos cordados (de FoxA até FoxO) graças a ferramentas de estudos de análise filogenética (Kaestner et al., 2000). Posteriormente, outras quatro subclasses foram catalogadas: FoxP, FoxQ, FoxR e FoxS (Hannenhalli e Kaestner, 2009).

Apesar de existirem semelhanças entre os domínios $f k h$ e, consequentemente também entre os motivos de reconhecimento ao DNA, as proteínas Fox possuem papeis diversos. Isso se deve em parte, às diferenças nos elementos de interação, como as enzimas modifícadoras e os cofatores e, em parte, às diferenças nos padrões de expressão espaço-temporal dos genes Fox (Hannenhalli e Kaestner, 2009).

As proteínas Fox participam de eventos biológicos importantes durante a fase embrionária, mas também tem funções específicas no indivíduo adulto (Lai et al., 1993; Kim et al., 2005; Ogasawara e Satou, 2003; Lehmann et al., 2003). A subclasse FoxO, por exemplo, atua na regulação do metabolismo, na resistência ao estresse oxidativo e na interrupção do ciclo celular (Jackson et al., 2010). Em condições de jejum, também ativa genes que codificam enzimas responsáveis pela neoglicogênese no fígado, apresentando também papel de repressor de tumorigênese in vivo (Kim et al., 2005). Além disso, as proteínas FoxA participam do controle do desenvolvimento de órgãos de múltiplos sistemas, os quais incluem fígado, pâncreas, pulmões, próstata e rins (Jackson et al., 2010). Um outro exemplo, a subclasse FoxP tem papel na resposta imune, mais especificamente o FoxP3. Dentro desta subclasse, FOXP2 tem um envolvimento no desenvolvimento da linguagem e mutações nesse gene foram associadas a desordens de fala e linguagem em seres humanos (Jackson et al., 2010) e no canto em pássaros (Haesler et al., 2004).

Com relação ao papel dos genes forkhead no desenvolvimento embrionário, pode-se citar o Foxh1 que quando deletado em camundongo (M. musculus), resulta na falha da formação da linha primitiva anterior (Hoodless et al., 2001). Esta estrutura participa na formação da notocorda e do endoderma definitivo (Hoodless et al., 2001). Foxb1 é expresso nos somitos dorsais nos estágios iniciais do desenvolvimento de camundongos (Labosky et al., 1997). Foxel é expresso no epitélio do intestino primitivo e nas células precursoras da glândula tireóide e a mutação nesse gene causa a agenesia da tireóide em camundongo e seres humanos (Macchia et al., 1999). 
A implicação de proteínas forkhead em vários processos morfogênicos sugerem que a crescente complexidade do plano corporal pode ter sido uma força motriz por trás da expansão dessa família (Carlsson e Mahlapuu, 2002). Entre os organismos que já tiveram seu genoma sequenciado completamente ou muito perto disso, existe realmente uma correlação entre a complexidade anatômica e o número de genes forkhead, sendo quatro para $S$. cerevisiae, 15 em C. elegans, 20 em D. melanogaster e pelo menos 43 em H. sapiens (Katoh e Katoh, 2004; Carlsson e Mahlapuu, 2002).

\subsection{Estrutura da proteína FoxN1}

A proteína FoxN1, também conhecida como Whn (Nehls et al. 1994), FKHL20, Rowett nude (RONU ou RNU) (Festing et al., 1978) e Hfh11, consiste em uma sequência de 648 aminoácidos para H. sapiens e para M. musculus. Dessa sequencia, $85 \%$ dos resíduos de aminoácidos são idênticos entre essas espécies, incluindo o domínio forkhead e o domínio de ativação transcricional (Figura 5 e 6). Assim como o gene em camundongo, o gene humano consiste em oito éxons codificantes (Figura 7) e utiliza dois éxons primários alternativos (1a e 1b) relacionados com expressão tecido-específica do gene (Schorpp et al., 1997).

De acordo com estudos de Schorpp et al. (1997), por análise de PCR retrotranscriptase (RT- PCR), o segundo éxon é na verdade o primeiro codificante, apresentando o códon iniciador (metionina) e dependendo da sequência desenhada com os dois primeiros éxons alternativos (1a e 1b), têm-se funções diferenciadas. Sendo assim, a sequência $1 \mathrm{a}-2$ é expressa tanto no timo quanto na pele, enquanto que a sequência $1 b-2$ é somente detectada na pele (Fig. 7), indicando que a atividade transcricional do gene Foxn1 está sujeita a uma regulação complexa (Schorpp et al., 1997). Sequências localizadas antes dos dois éxons primários alternativos tem atividade promotora.

Em seres humanos o gene FOXN1 se localiza no cromossomo 17q11.2, e em camundongo no cromossomo 11. A sequência proteica C-terminal do domínio $f k h$ de FoxN1 (Anexo 1) apresenta um grande número de aminoácidos carregados negativamente e exibe uma alta proporção de resíduos de prolina (Nehls et al., 1994) e está localizado entre os resíduos 270 a 362 na sequencia, aproximadamente (Figura 8). 


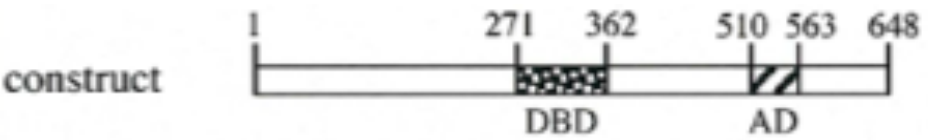

Figura 5. Representação esquemática do fator de transcrição Foxn1 de camundongo. DBD, domínio de ligação ao $D N A, \mathrm{AD}$, domínio de ativação transcricional. Figura retirada do artigo Schlake et al. (2000).
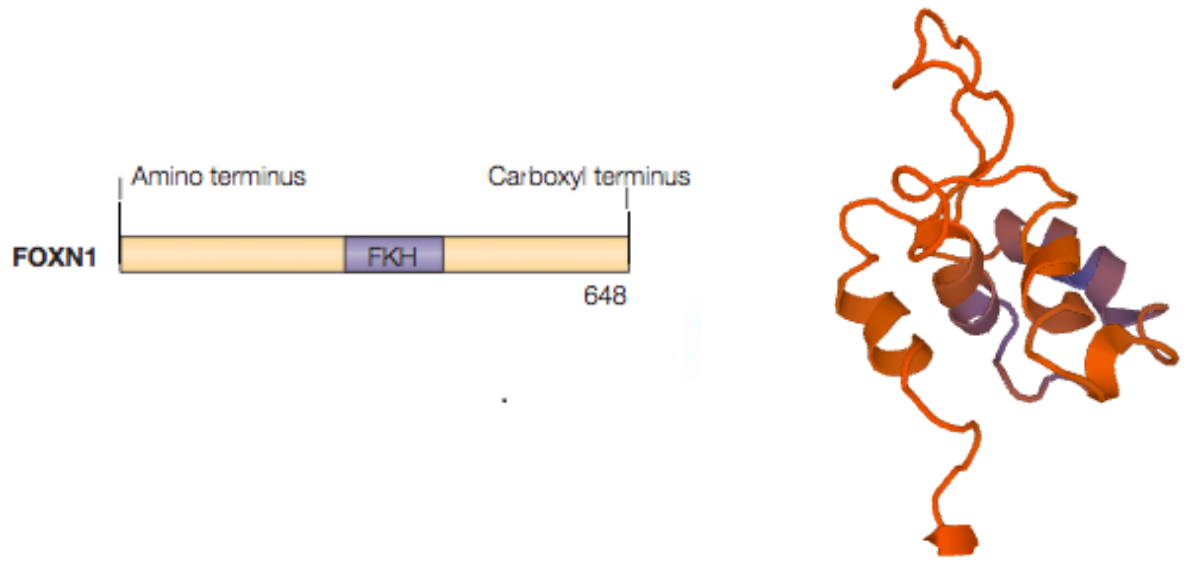

Figura 6. Representação do domínio forkhead $(f k h)$ de Foxn1. A imagem à esquerda, retirada do artigo Coffer e Burgering (2004), representa a localização aproximada do domínio $f k h$ de Foxn1, assim como o tamanho da sua sequência. A figura à direita, foi construída a partir da sequência de aminoácidos da proteína FoxN1 de G. gallus pelo software SwissModel (http://swissmodel.expasy.org/interactive/9KYPpJ/models/) mostra a estrutura 3D da região desse domínio.

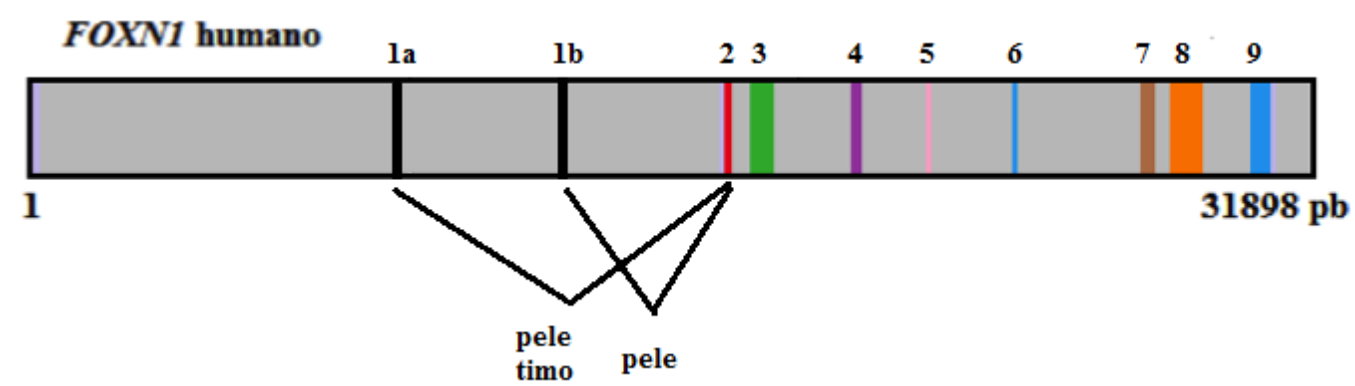

Figura 7. Representação da estrutura do gene FOXN1 em H. sapiens. O gene contém aproximadamente 32 mil pares de bases e apresenta oito éxons codificantes (iniciando no éxon 2), mostrados em cores no desenho. Os dois éxons alternativos são representados em preto por $1 \mathrm{a}$ e $1 \mathrm{~b}$ e sua combinação com o éxon 2 resulta na expressão tecido específico em $H$. sapiens. 


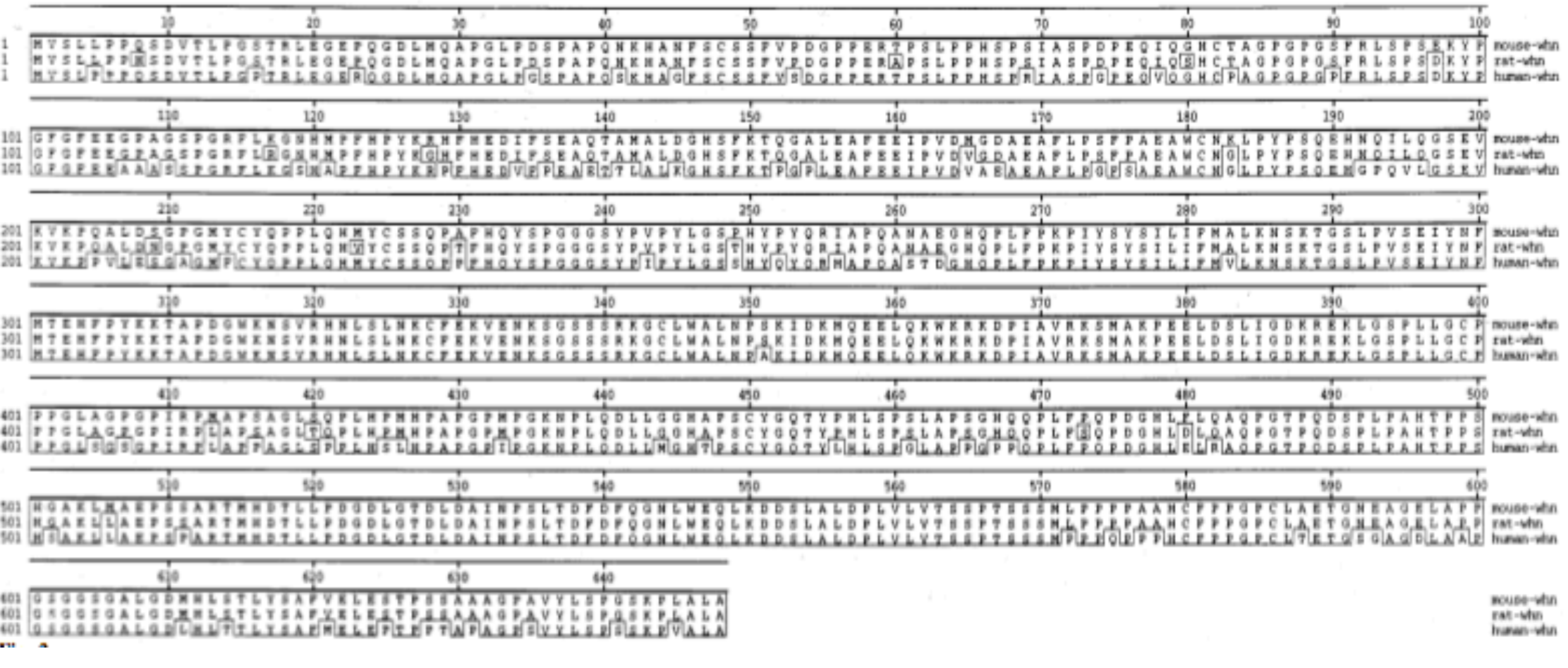

Figura 8. Comparação da sequência de aminoácidos das proteínas FOXN1 de humanos, camundongos e ratos. O domínio de ligação ao DNA compreende os resíduos 271 a 362, o domínio de ativação transcricional compreende os resíduos 509 a 563. Observe que as sequências de polimorfismos entre o cDNA de $F O X N 1$ humano e o gene FOXN1 humano contidos em clones genômicos P1 levam a mudanças de aminoácidos nas posições 283 (V>A) e 599 (A>P). Figura retirada do artigo Schorpp et al. (1997). 


\subsection{Funções de FoxN1}

FoxN1 exerce papeis cruciais no desenvolvimento das células epiteliais cutâneas e do timo (Jonsson e Peng, 2005). Sua associação com o desenvolvimento do timo tem como consequência seu envolvimento no sistema imunológico, pois, quando mutado - evento que elimina o domínio de ligação ao DNA - resulta em defeitos no desenvolvimento das células T, além do não desenvolvimento de pelos. O padrão de expressão de Foxn1 em camundongo, durante o desenvolvimento embrionário foi encontrado a partir do estágio E13.0, momento em que a embriogênese já está completa, pode ser visto na Figura 9.

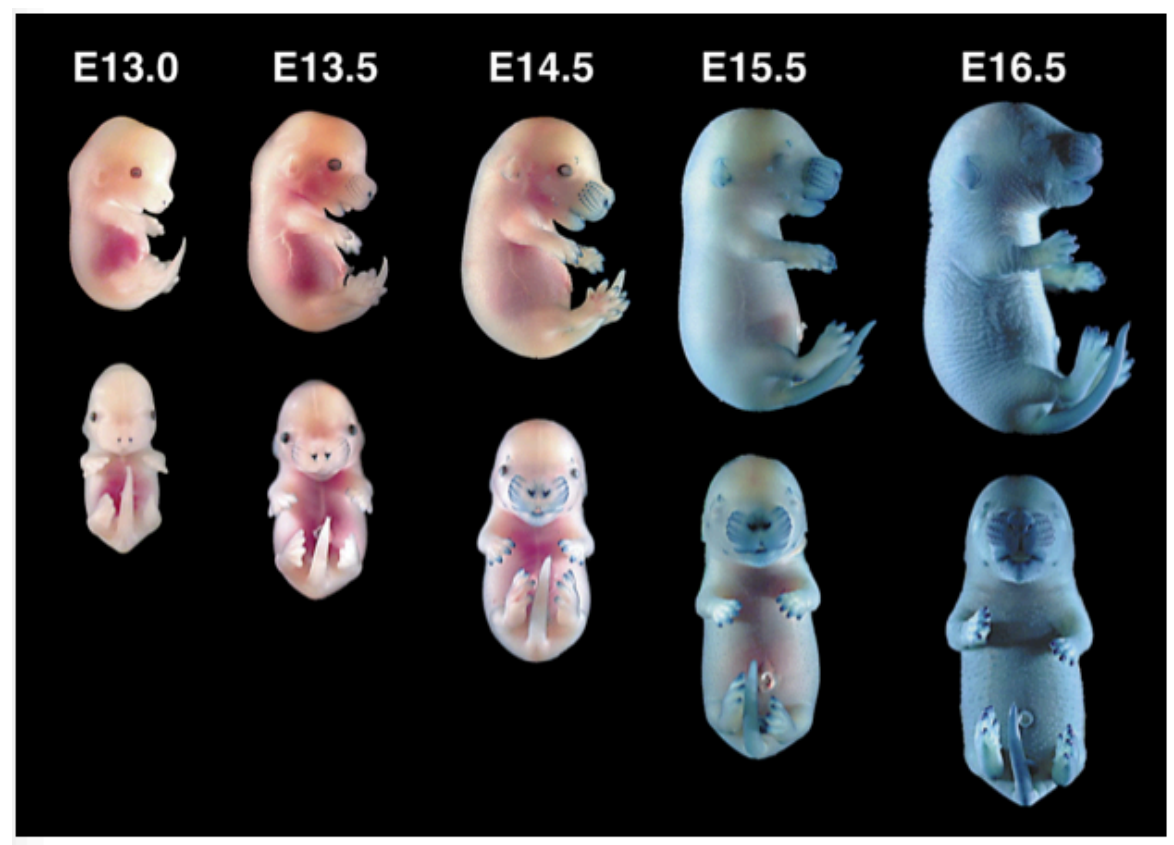

Figura 9. Padrão de expressão de Foxn1 durante o desenvolvimento embrionário de camundongos. Os embriões de camundongo (M. musculus) foram marcados para mostrar a atividade de $\beta$-galactosidase (azul). Os estágios embrionários estão indicados. Figura retirada do artigo Lee et al. (1999).

Foxn1 começa a ser expresso no primórdio da terceira bolsa faríngea, a qual dará origem ao timo e a glândula paratireoide (Gordon et al., 2001).

FOXN1 exerce papel essencial no programa de desenvolvimento normal do epitélio tímico. Esse órgão é um órgão linfoide primário que tem a função de manter uma quantidade viável de células T maduras e funcionais (Romano et al., 2013). As células T, por sua vez, exercem diversos papeis imunológicos, entre eles o reconhecimento de antígenos próprios e não-próprios do organismo e também gerencia o desenvolvimento dos linfócitos B. As etapas 
do processo de desenvolvimento dos linfócitos T é estritamente controlada por uma rede de eventos transcricionais que medeiam a proliferação, sobrevivência e desenvolvimento das células T (Anderson e Jenkinson, 2001). A expressão de FOXN1 é importante porque na sua ausência, a colonização do primórdio do timo pelas células progenitoras das células $\mathrm{T}$ originadas da medula óssea falha e o desenvolvimento subsequente das células $\mathrm{T}$ e a formação do epitélio tímico é abortado (disgenesia), resultando em uma imunodeficiência grave, conhecida como a síndrome de imunodeficiência combinada severa (SCID).

Em seres humanos e em camundongos, as células epiteliais do timo primordial (CET) após passarem pelo estágio de crescimento e proliferação ainda não são funcionalmente competentes para apoiar o desenvolvimento dos linfócitos T. Somente após a ativação transcricional de FOXN1 no epitélio é que essa função é adquirida. Dessa forma, FOXN1 age como um gene regulador das linhagens de CET em que promove a transcrição downstream de genes relacionados com a organogênese do timo e com a diferenciação completa das CET (Figura 10). Esses genes são Hoxa3 - envolvido na habilidade das células da crista neural de se diferenciarem e/ou de levarem à diferenciação dos tecidos do arco e bolsa faríngea -, CCL25 e Dll4, que tem papel principal no desenvolvimento dos timócitos, onde CCL25 regula a colonização do timo fetal, podendo provocar quimiotaxia em timócitos imaturos (Jonsson e Peng, 2005), enquanto que Dll4 está envolvido com o comprometimento dos progenitores hematopoiéticos com as linhagens de células T (Romano et al., 2013).

$\mathrm{O}$ fenótipo nude de camundongos existe de forma equivalente em seres humanos, $\mathrm{o}$ que foi primeiramente descrito em duas irmãs em 1996 (Romano et al., 2012). A Nude/SCID humana é uma desordem autossômica recessiva, que tem como marca a completa ausência funcional do timo. Uma mutação em FOXN1, descrita como a transição de C792T que resulta na mutação nonsense R255X no quinto éxon desse gene, contribui para o aparecimento dessa síndrome, que além de consistir em uma deficiência nas células T, também acarreta a alopecia congênita e distrofia nas unhas (Jonsson e Peng, 2005).

Sua expressão na matriz ungueal, onde as placas ungueais se originam, confirmam que esse fator de transcrição também tem um papel importante no processo de maturação das unhas e sugere a distrofia das unhas como um sinal indicativo de heterozigose (Romano et al., 2012). Mais detalhadamente, Foxn1 influencia a expressão de queratina rígida durante a diferenciação das unhas (Cai e Ma, 2011). Assim, existindo a mutação em Foxn1, as unhas aparentam estar mais quebradiças e finas em relação ao fenótipo normal. 


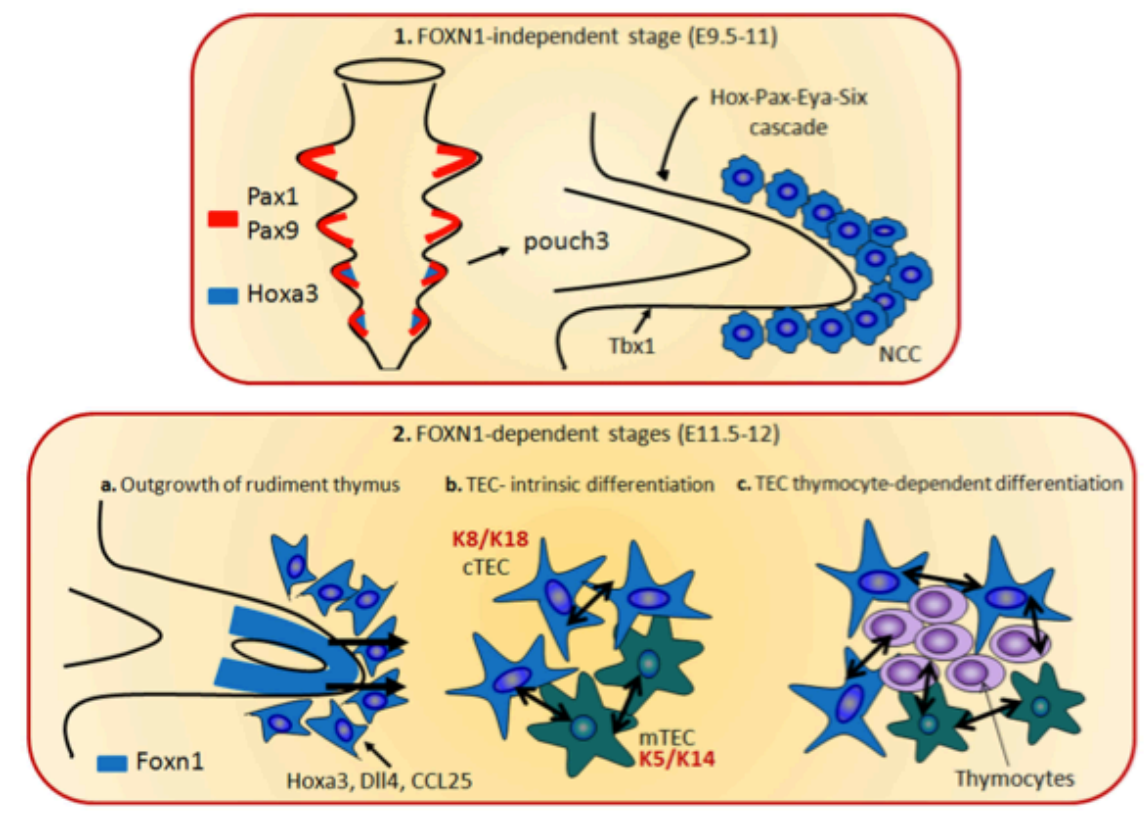

Figura 10. Organogênese do timo. A organogênese do timo é caracterizada por duas fases genéticas. A primeira é independente da expressão de FOXN1 (1) e consiste na indução e crescimento do primórdio epitelial do timo a partir da terceira bolsa faríngea, através da expressão de genes que incluem EYA1, Six, Hoxa 3 e Tbx1. Na fase dois, FOXN1 regula a expressão de CCL25, Dll4 e Hoxa3, necessários para diferenciação dos timócitos e das CET (2). Durante esse passo, CET corticais (expressando como marcadores as queratinas 8 e 18) e medulares (expressando como marcadores as queratinas 5 e 14) se originam do mesmo progenitor de CET. O crosstalk entre as CET e os timócitos em desenvolvimento é requerido para gerar TEC completamente maduras e células $\mathrm{T}$ funcionais. Retirado do artigo Romano et al. (2013).

Outro papel importante no qual Foxn1 está envolvido é no correto desenvolvimento dos pelos. $\mathrm{Na}$ epiderme e folículos capilares de murinos, as mutações nude prejudicam a diferenciação terminal, uma vez que várias estruturas diferenciadas (como o estrato córneo, o córtex capilar e a cutícula capilar) não se formam propriamente (Baxter e Brissette, 2002), resultando na formação de uma epiderme hiperplástica. Durante o desenvolvimento da pele, as células epiteliais induzem a expressão de Foxn1 logo que os primeiros sinais de diferenciação terminal começam a aparecer (Lee et al., 1999).

Na epiderme, Foxn1 é expresso na camada supra-basal e promove a diferenciação inicial dos queratinócitos (Lee et al., 1999). Também está expresso na região supra-matricial do bulbo capilar, local onde acontecem os primeiros estágios de diferenciação terminal (Baxter e Brissette, 2002) e que dará origem aos fios de cabelo e a bainha interna da raiz (Prowse et al., 1999). No ciclo de formação do folículo capilar, Foxn1 parece estar fortemente expresso na fase de crescimento e sua expressão diminui na fase quiescente desse ciclo (Darnell et al., 2014). 
Na ausência de Foxn1, o fio de cabelo/pelo exibe uma estrutura mais fraca, perde a rigidez, uma vez que ele se dobra, enrola-se e quebra-se dentro do canal capilar, raramente emergindo na superfície da pele (Mecklenburg et al., 2001) (Figura 11).

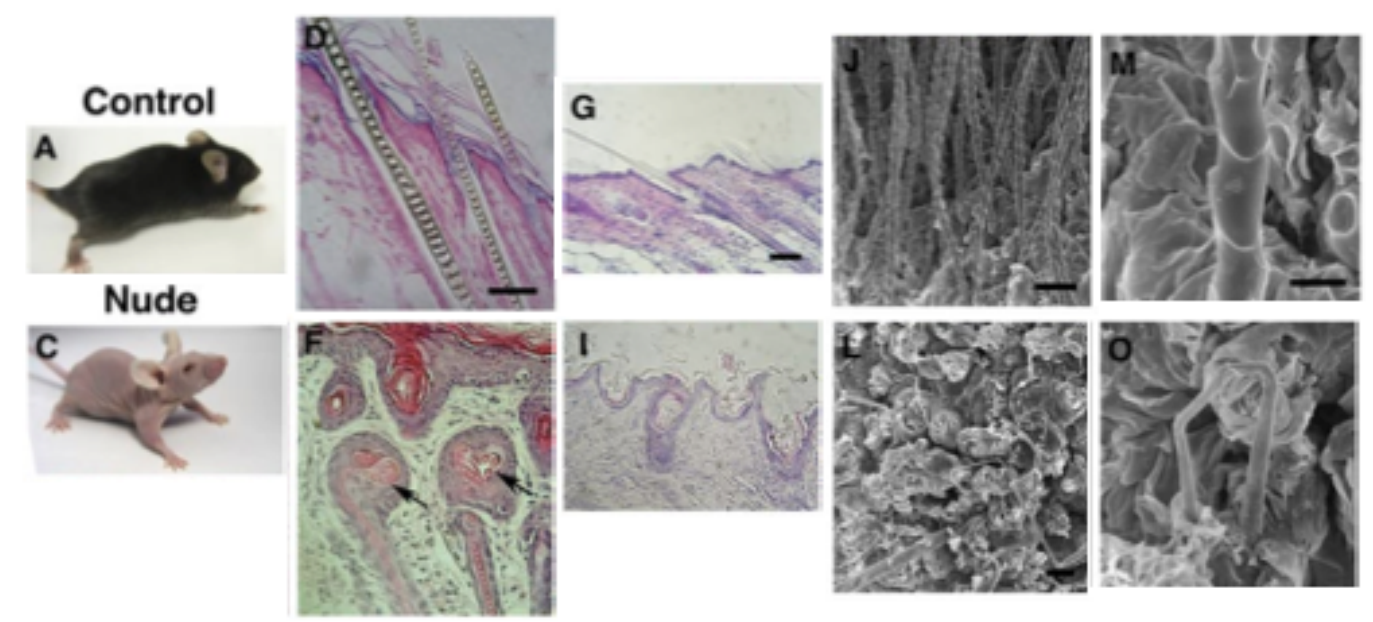

Figura 11. Diferenças na pele e pelos entre camundongo controle e nude (Foxn1 -/-). (A e C) vista macroscópica dos camundongos controle (A) e nude (C). (D - I) secções da pele dorsal coradas com H\&E do camundongo controle (D e G) e nude (F e I). (D e F) mostram as secções de camundongo com 8 dias após nascimento e (G e I) mostram as secções de camundongo com 28 dias após nascimento. Os fios de cabelo no camundongo nude (setas em F) estão dobradas em P8 em relação ao controle. ( $\mathrm{J}-\mathrm{O}$ ) imagens de microscopia eletrônica de varredura. ( $\mathrm{J}$ e M) controle e ( $\mathrm{L}$ e O ) nude em P28. Muitos cabelos são visíveis na pele do camundongo controle $(\mathrm{J})$, enquanto que relativamente poucos fios são visíveis no camundongo nude (L). Os filamentos de pelos do camundongo controle têm uma cutícula normal (M), enquanto que no camundongo nude falta a cutícula e os fios estão dobrados (O). Barras de escala, $50 \mu \mathrm{m}$. Figura retirada e adaptada do artigo Nakamura et al. (2008).

Além dessas funções já estudadas e encontradas na literatura científica, existem também outros trabalhos que relacionam FoxN1 com outros papeis, como o de Zhang et al. (2010) que mostra que o knockout de Foxn1 em camundongos machos isogênicos suprime componentes feromônios na urina e por consequência, suprime a atração das fêmeas. Morrison et al. (2004) também mostrou que a mutação nude em camundongos retarda o desenvolvimento precoce do crescimento muscular dos membros, mas não afetando o tecido matriz desses músculos.

\subsection{FoxN1 e o desenvolvimento do Sistema Nervoso Central}

O desenvolvimento do sistema nervoso central (SNC) em seres humanos inicia-se pela formação da placa neural durante a terceira semana após a fecundação, dando origem às pregas neurais, que, mais tarde se encontram para formar o tubo neural (Wolpert et al., 2000). 
O tubo neural é importante pois representa o primórdio desse sistema, diferenciando-se em SNC e medula espinhal. O sistema nervoso periférico e autônomo são originados a partir de células da crista neural (Nelms e Labosky, 2010). Sabendo disso, uma perturbação no processo de neurulação pode resultar em anormalidades graves na formação do encéfalo e da medula espinhal, conhecidos como defeitos no tubo neural (DTN).

Estes defeitos resultam na geração de parte do tubo neural aberto e exposto na superfície do embrião ou recoberto por pele (Schoenwolf et al., 2009). DTN abertos são mais severos e vão de disrafias totais, quando há falha generalizada no processo de fechamento do tubo neural, a parciais, quando somente parte do tubo encontra-se aberto, como por exemplo, a espinha bífida aberta, onde a região lombar da medula espinhal não se fecha e a anencefalia, onde há falha de fechamento no tubo neural na região cefálica.

Quanto à natureza, alguns defeitos do SNC estão associados a fatores externos (ambientais) ou fatores internos (genéticos ou multifatoriais). De todos os defeitos, os menos compreendidos são aqueles relacionados a mutações em um único gene, de modo que ainda existe uma grande carência de estudos que esclareçam a função destes defeitos (O'Harilly, 2001; Farley, 2006). Já foi visto que quase 200 mutações em camundongos resultam em neurulação defeituosa. Portanto, conhecer estas mutações ajuda na compreensão de processos na neurulação, bem como as anomalias relacionadas a essa etapa de desenvolvimento. (Schoenwolf et al., 2009).

Amorosi e colaboradores estudaram dois casos de fetos humanos que pertenciam a uma família italiana, que apresentavam uma mutação (R255X) em FOXN1 e foram abortados (Amorosi et al, 2008; Amorosi et al., 2010). Ambos os fetos foram examinados e o indivíduo descrito no primeiro trabalho (2008) apresentava anencefalia e espinha bífida (Figura 12). No segundo feto (2010), uma análise morfológica mostrou que ele possuía entre outros, uma má formação do corpo caloso (Figura 13).

Ademais foi visto que Foxnl é expresso no plexo coróide (PC) em embriões de camundongos (Figura 14) (Amorosi et al., 2008). O plexo coróide é uma estrutura cerebral que está localizado estrategicamente em todos os ventrículos cerebrais. Suas células têm a função de secretar o líquido cefalorraquidiano (LCR). Esse líquido preenche todo o cérebro passando por entre os ventrículos e a composição desse fluido inclui moléculas chave para a manutenção do ambiente cerebral, como fatores angiogênicos e tróficos e proteínas carreadoras. Redzic et al. (2005) sugerem também que o sistema plexo coróide-LCR também exerce um papel muito mais ativo no desenvolvimento, homeostase e reparo do SNC. Durante o desenvolvimento do SNC, os fatores de crescimento derivados do PC, como o ácido 
retinóico, exercem um papel importante no controle do padrão da diferenciação neuronal em diversas regiões cerebrais (Redzic et al., 2005).
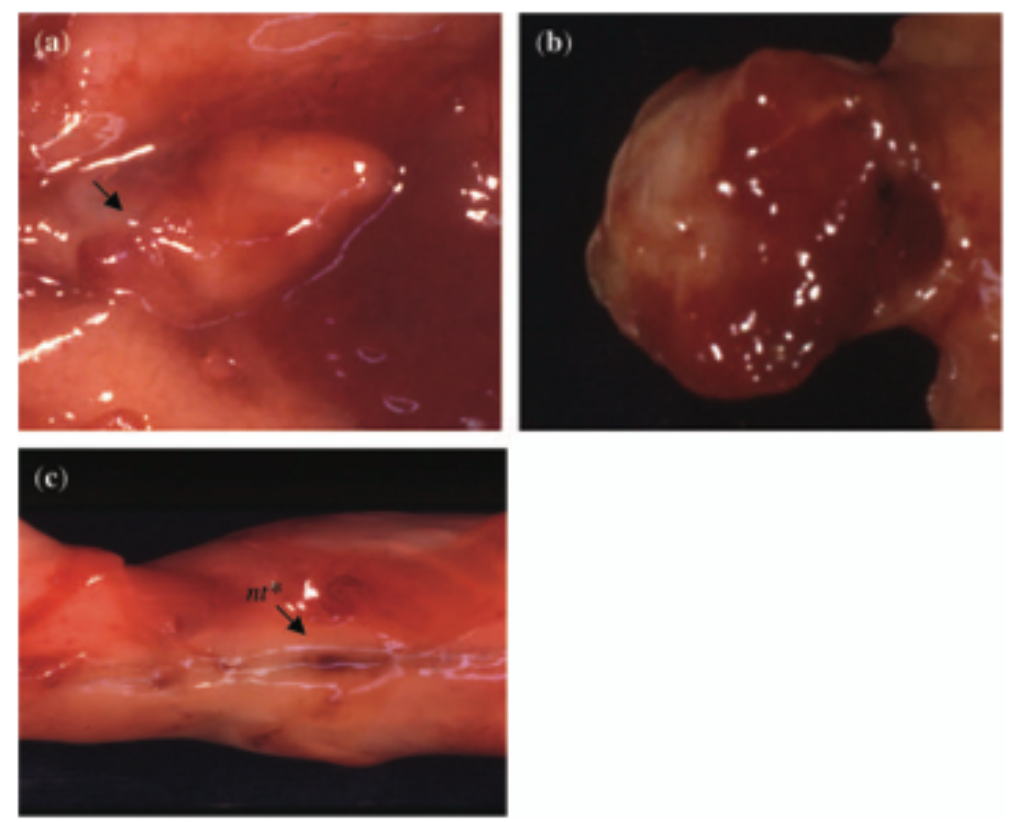

Figura 12. Fenótipo morfológico de um feto humano FOXN1 -/. A gravidez foi interrompida na 15 semana. A pele estava muito junta, brihante e lisa. (a) Vista ventral do feto mostrando a ausência de timo no peitoral. A seta indica o local usual do timo. (b) Vista dorsal mostrando o crânio do feto. Anencefalia completa caracterizada pela ausência do escalpo, calvário e cérebro. (c) Vista dorsal mostrando a raquisquise crânio espinhal. nt*, espinha bífida. Figura retirada do artigo Amorosi et al. (2008). 

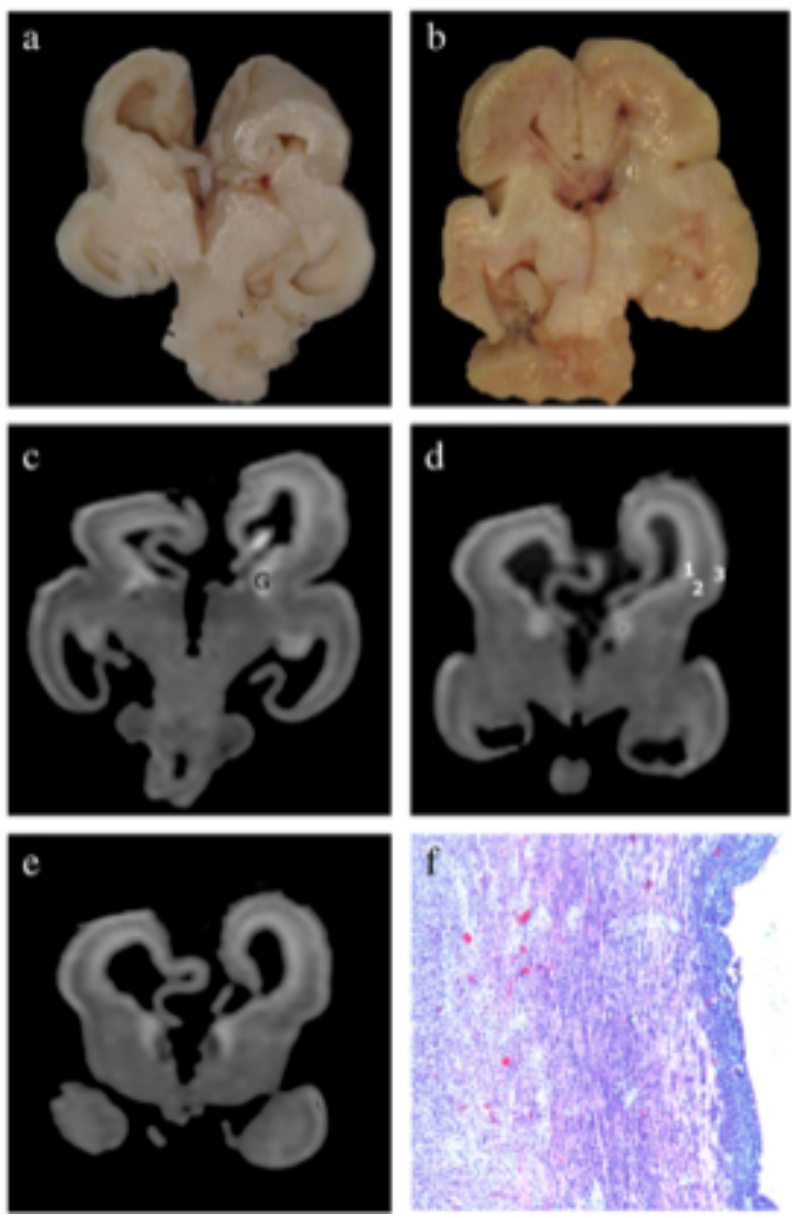

Figura 13. Secções cerebrais do feto homozigoto recessivo para FOXN1. (a) uma secção coronal do cérebro, atravessando o tronco cerebral e o mesencéfalo em um feto Nude/SCID revelou uma anormalidade no desenvolvimento do corpo caloso. (b) uma secção coronal do cérebro, em um feto controle na mesmo tempo gestacional (18 semanas), revelou uma estruturas bem formada na linha média com a presença do corpo caloso, cujas fibras a linha média e a do septo pelúcido. (c-e) exame de ressonância mostando a integridade das principais estruturas. O corpo caloso não pode ser identificado em três planos coronais paralelos no nível do tronco cerebral (c), corpos mamilares (d) e núcleo acumbens (e). Eminência gangliônica (G) está indicada e camadas fetais transitórias, incluindo a matriz germinal periventricular e zona intermediária (1), zona subplaca (2) e placa cortical (3) estão indicadas. (f) secção do cérebro corada com H\&E mostrando a presença de feixes nervosos, localizados medial ao ventrículo lateral. Esses feixes mostram axônios presos que não cruzaram a linha média por causa da ausência de corpo caloso no feto investigado. x50. Figura retirada do artigo Amorosi et al. (2010). 


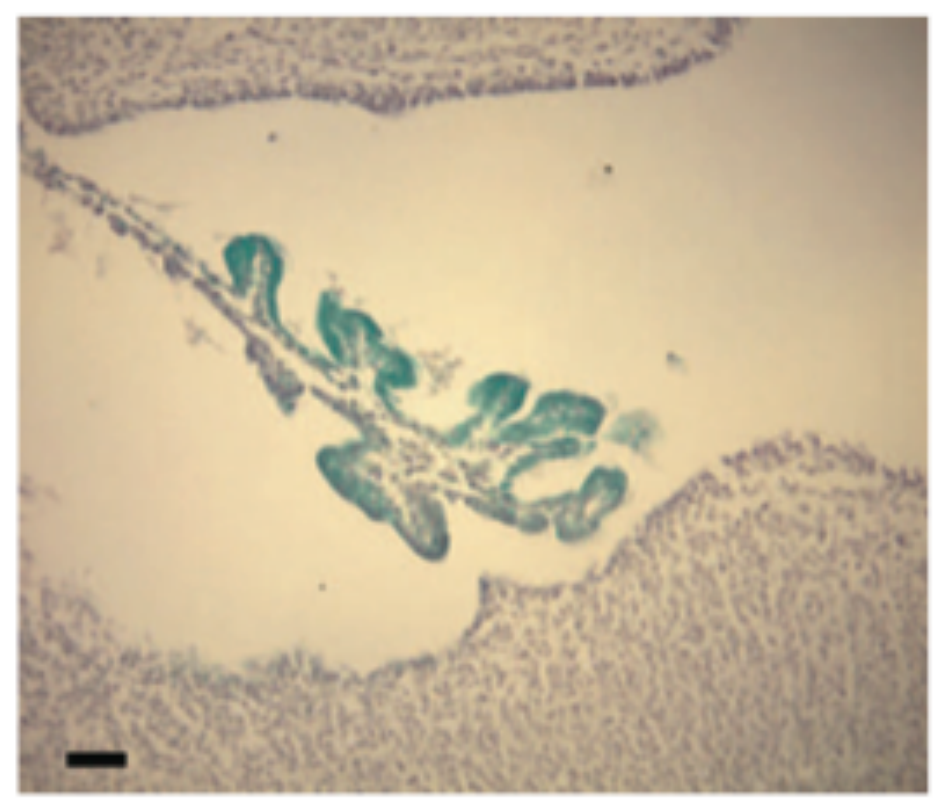

Figura 14. Expressão de Foxn1 em cérebro de embriões de camundongos. O gene de $\beta$-galactosidase foi inserido no locus de Foxn1 por recombinação homóloga. Embriões heterozigotos $\left(F_{0 x n 1+/ F o x n 1}{ }^{\text {lacZ }}\right)$, que são fenotipicamente normais, foram corados para a atividade de $\beta$-galactosidase (azul). Foxnl é expresso por todo o epitélio do plexo coróide em desenvolvimento. Barra de escala $50 \mu \mathrm{m}$. Figura retirada do artigo Amorosi et al. (2008).

O plexo coróide diferencia-se de células ependimárias margeando as paredes ventriculares. O PC do quarto ventrículo se forma primeiro, seguido pelos ventrículos laterais e o terceiro ventrículo (Dziegielewska et al., 2001). Interessantemente, o tubo neural é preenchido por fluido antes dos PCs serem formados (Miyan, 2009), lançando a questão se células similares às dos PCs são capazes de secretar LCR antes da morfogênese deles (Redzic et al., 2005).

O LCR também é essencial para a manutenção da pressão interna no sistema ventricular, pois isso é crítico para o desenvolvimento normal do SNC. Desmond e Jacobson (1977) fizeram um experimento com embriões de galinha em que demonstraram que a drenagem do LCR de dentro do sistema ventricular causa anormalidades significativas no que diz respeito à organização neuronal do cérebro em desenvolvimento.

Estes dados reforçam a hipótese de que FOXN1 pode ter alguma função no desenvolvimento do SNC, além das suas funções já descritas. Amorosi et al. (2008) sugerem que distúrbios na secreção do LCR podem ter um papel na patogênese dos defeitos do tubo neural, como os já citados. O autor sugere que a mutação do gene FOXN1 pode estar envolvida com a formação de uma estrutura que é característica da anencefalia humana: a área 
cerebrovasculosa (proliferação fibrovascular geralmente atribuída a uma resposta encefaloclástica da exposição direta do tecido neural ao fluido amniótico, resultando em efeitos tóxicos) (Amorosi et al., 2008).

Uma outra hipótese, sugerida pelo autor, é que FOXN1 atue como um cofator no desenvolvimento do SNC, assim como outras proteínas da família Fox, como por exemplo Foxp1, que atua auxiliando as proteínas Hox na regulação de genes que controlam a diversificação neurônio-motora (Amorosi et al., 2010). No caso da proteína Foxn1, já se sabe que ela é requerida para manter a expressão de Notch1 na matriz folicular (Cai et al., 2009), onde esta regula a especificação do destino celular e do padrão de formação no SNC em desenvolvimento.

\subsection{Desenvolvimento inicial do Sistema Nervoso Central.}

As etapas de segmentação e de gastrulação em vertebrados mostram-se diferentes para cada espécie, já a fase pós gástrula aproxima a morfologia entre os grupos, mostrando-a bastante similar, caracterizando o início do período embrionário (Dias, 1996). Nesta etapa do desenvolvimento, através dos processos morforganogenéticos, são estabelecidos os primórdios da forma e da organização interna do organismo comuns ao grupo e específicos a nível de diversidade das espécies (Shostak, 1991; Duboule, 1994).

Nas aves, o eixo ântero-posterior está orientado no blastoderma, durante a clivagem do ovo em sua passagem através do oviduto. Em G. gallus, o processo de segmentação já está concluído no momento da ovopostura, a partir do qual, a dinâmica do desenvolvimento tem curso em temperatura e umidade de incubação adequadas, efetivando-se os processos de gastrulação e de neurulação (Dias, 1996). Uma vez formados, os três folhetos germinativos (endoderme interna, mesoderme intermediária e ectoderme externa) diferenciam-se progressivamente e até o final do quarto dia de incubação estabelecem-se os primórdios das principais estruturas formadoras do corpo do animal. Neste período são marcantes os aspectos da diferenciação do ectoderma neural e consequentemente a importância que o sistema nervoso assume no estabelecimento da forma do corpo do embrião, o qual destacando-se do vitelo subjacente, torna-se mais evidente (Eyal-Giladi, 1991; Eyal-Giladi et al., 1992).

Durante o processo de neurulação primária, ocorre a interação da mesoderme dorsal com ectoderme que a recobre para formar a placa neural, que mais tarde, ao se fechar, formará o tubo neural oco que irá diferenciar-se em cérebro e medula espinhal (Gilbert, 2003) (Figura 15). Na extremidade cefálica do tubo neural, a parede é larga e espessa, pois é neste 
local que uma série de intumescências e constrições definirão os diversos compartimentos cerebrais (metencéfalo, mesencéfalo, diencéfalo, telencéfalo e mielencéfalo) (Gilbert, 2003; Moore et al., 2013).

Essa diferenciação do tubo neural ocorre simultaneamente em três níveis diferentes. Ao nível anatômico, o tubo neural e seu lúmen se dilatam e se estreitam para formar as cavidades do cérebro e da medula espinhal. Ao nível do tecido, as populações celulares da parede do tubo se rearranjam de várias maneiras para formar as diferentes regiões funcionais do cérebro e da medula espinhal. Finalmente, ao nível celular, as células neuroepiteliais se diferenciam nos numerosos tipos de neurônios e células gliais (Gilbert, 2003).

O arranjo das células do epiblasto desempenha uma função importante no processo de neurulação, sendo possível definir três populações distintas de células ectodérmicas prospectivas (Dias, 1996). A primeira consiste de células do tubo neural, a segunda de células da epiderme da pele e a terceira, de células da crista neural, representadas pelas células mais dorsais do tubo neural (Fig. 15) (Gilbert, 2003).

As células da crista neural são tão importantes que às vezes tem sido chamadas de quarto folheto germinativo, porque elas migram extensivamente e dão origem a um número desconcertante de tipos celulares diferenciados, incluindo os neurônios e células da glia, células pigmentares da epiderme, células do tecido ósseo e conjuntivo e de componentes da cabeça (Gilbert, 2003), estando envolvidas na formação dos mesênquimas dos arcos faríngeos do embrião.

O primeiro arco faríngeo, em seres humanos, dará origem à mandíbula, à ossículos da orelha média (bigorna e martelo) e a uma grande porção da musculatura facial. O segundo arco faríngeo, também dará origem a um ossículo do ouvido (estribo), assim como a maior parte da cartilagem da face (Moore et al., 2013). Os terceiro, quarto e sexto (o quinto se degenera em humanos) arcos faríngeos produzirão os ossos e músculos do pescoço (Moore et al., 2013).

A faringe primitiva, derivada do intestino anterior, se alarga cefalicamente no local onde se une ao estomodeu, e se estreita à medida que se une ao esôfago (Moore et al., 2013). $\mathrm{O}$ endoderma da faringe reveste os aspectos internos dos arcos faríngeos e passa para as bolsas faríngeas. As bolsas se desenvolvem em uma sequência cefalocaudal entre os arcos (Moore et al., 2013). 


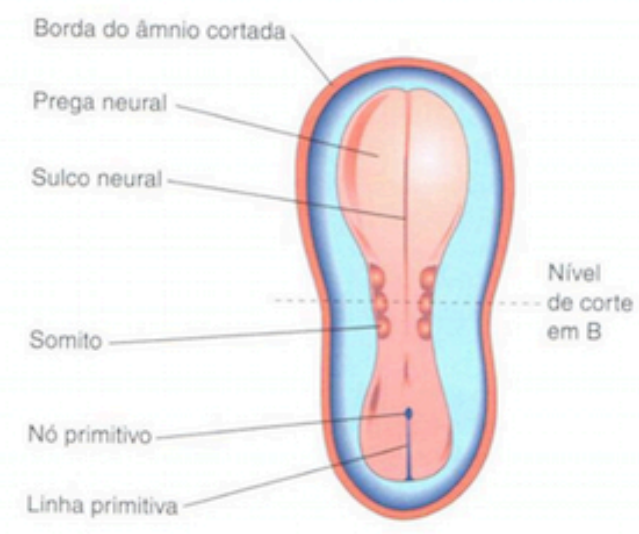

A
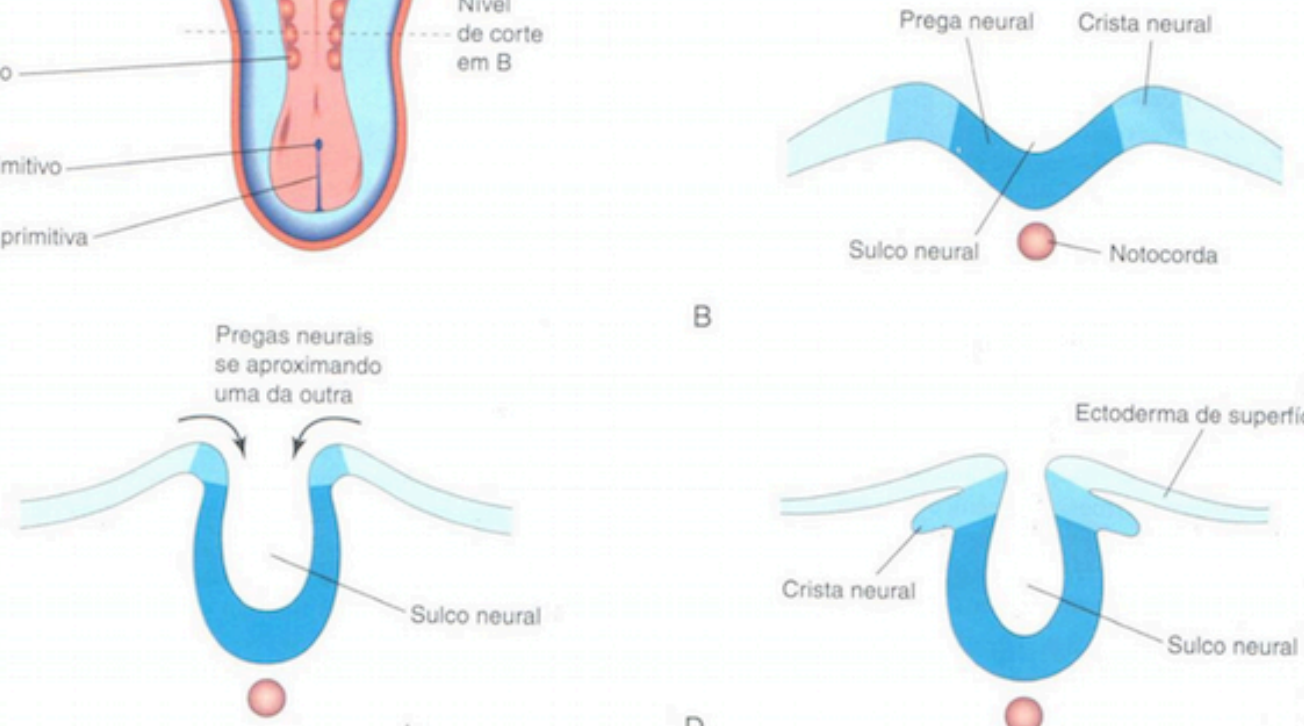

B
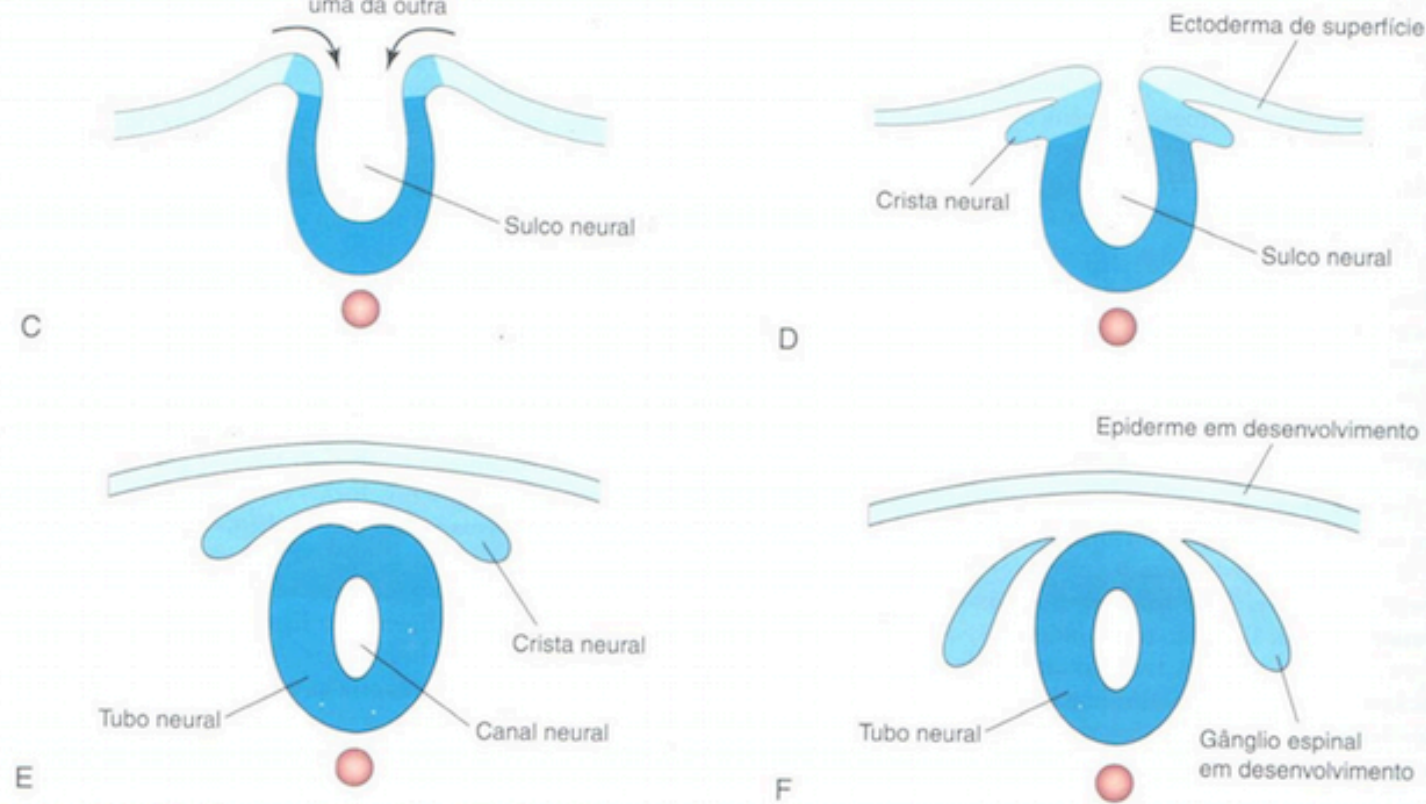

Figura 15. Esquemas de cortes transversais através de embriões progressivamente mais velhos ilustrando a formação do tubo neural. Em A, vista dorsal de um embrião de aproximadamente humano de 21 dias. B, o alongamento das células ectodérmicas dorsais faz com que essa região neural presuntiva cresça mais que a ectoderme adjacente, criando assim, a PLACA NEURAL. Logo em seguida, as bordas da placa neural se espessam e deslocam-se para cima para formar as PREGAS NEURAIS enquanto um SULCO NEURAL em forma de U aparece no centro da placa, dividindo os futuros lados direito e esquerdo do embrião (Gilbert, 2003). C, as pregas neurais migram em direção à linha média do embrião, unindo-se (Gilbert, 2003). D, à medida que as pregas neurais se aproximam, as células da porção mais dorsal do tubo neural transformam-se nas células da CRISTA NEURAL (Gilbert, 2003). E, uma vez unidas as pregas neurais, têm-se a formação do tubo neural oco, com a camada de células da crista neural logo acima (Gilbert, 2003). F, as células da crista neural migrarão pelo embrião e darão origem a várias populações celulares, inclusive às do sistema nervoso periférico, como os gânglios (Gilbert, 2003). Em vermelho, está representada a notocorda. Figura retirada de Moore et al. (2013). 
O timo desenvolve-se a partir das células epiteliais derivadas do endoderma do terceiro par de bolsas faríngeas e do mesênquima no qual os tubos epiteliais crescem. Além disso, o primórdio tímico é cercado por uma fina camada de mesênquima que é fundamental para o seu desenvolvimento (Moore et al., 2013). Dessa forma, as células da crista neural também contribuem para a organogênese do timo.

2.10. Estudos com organismos modelo na embriologia.

Com o advento de técnicas da biologia molecular, celular e genética, as áreas de pesquisa em Ciência conseguiram passar para novos patamares, inclusive a embriologia, que se utiliza dessas técnicas para acompanhar, estudar e caracterizar o desenvolvimento dos seres vivos.

Para facilitar esses estudos são utilizados organismos modelo que auxiliam na compreensão de numerosos processos biológicos. Esses animais são o camundongo $(M$. musculus), a rã africana (X. laevis), a galinha (G. gallus), o zebrafish (D. rerio), o verme nematóide (C. elegans), a levedura S. cerevisiae, a mosca da fruta (D. melanogaster) e o ouriço do mar (P. lividus). Esses organismos modelo são chamados assim porque apresentam características que são vantajosas para quem faz estudos em laboratórios de pesquisa, tais como: o período de desenvolvimento mais rápido e curto ciclo de vida (Gilbert, 2003), adultos de porte pequeno, a fácil manutenção e obtenção desses animais (Griffiths et al., 2009). Eles representam uma pequena fração de todos os organismos existentes na Terra, mas as pesquisas e achados que resultaram do estudo com eles formam hoje núcleo do conhecimento em biologia (Hedges, 2002).

Estudos também já mostraram haver uma similaridade muito próxima no desenvolvimento de vários animais, assim como os mencionados (Figura 16), como o padrão corporal, a função semelhante de órgãos distintos quando se comparam dois animais de espécies diferentes (como insetos e humanos) mostrando que há como fazer correlações de hipóteses e resultados entre espécies, sendo um propósito válido para os estudos com organismos modelo (Veraska et al., 2000). 


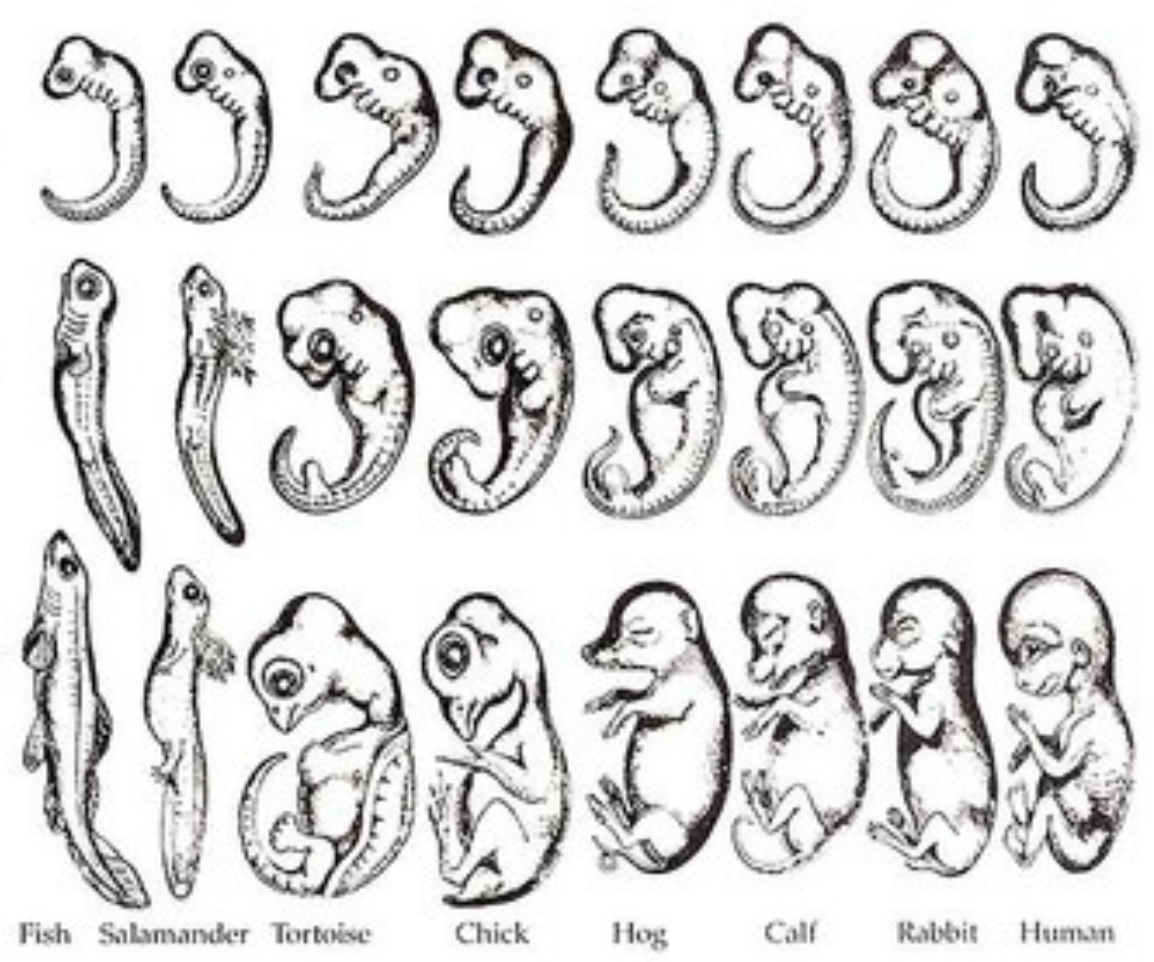

Figura 16. Desenho que representa etapas de desenvolvimento de alguns animais, sendo eles o peixe, a salamandra, a tartaruga, a galinha, o porco, o vitelo, o coelho e o ser humano. A figura mostra as semelhanças entre os embriões das diferentes espécies e as diferenças com o jovem nascido. Desenho do século XIX, adaptado por Haeckel, segundo Romanes (1901).

Os camundongos apresentam uma constituição genética muito similar à nossa, sendo que seu genoma, dentre os organismos modelo, é o que mais se assemelha ao genoma humano (Griffiths et al., 2009). Além disso, aproximadamente $99 \%$ dos genes de camundongo parecem ter homólogos em humanos e muitos deles são sintênicos com o de humanos, isto é, existem grandes blocos contendo os mesmos genes e nas mesmas posições em ambas as espécies (Griffiths et al., 2009). Toda essa similaridade genética contribui para o sucesso dos camundongos como organismos modelo.

A galinha é um organismo modelo evolutivamente intermediário, localizado entre os mamíferos e os vertebrados mais distantes, como o ouriço do mar e o zebrafish (Groenen et al., 2000). Existem muitos motivos pelo interesse do estudo do genoma da galinha (Tiersch e Watchtel, 1991). Por exemplo, o seu genoma é um terço do genoma de mamíferos porque apresenta menos sequências repetitivas e íntrons menores (Hughes e Hughes, 1995) e além disso, o nível de sintenia entre galinhas e humanos aparenta ser muito alto (Jones et al., 1997; Groenen et al., 1999; Nanda et al., 1999). 
Ademais, visualizar o desenvolvimento embrionário na galinha é uma tarefa fácil, uma vez que cada etapa da morfogênese e organogênese do embrião pode ser acompanhada a cada estágio in vivo, incluindo a etapa da neurulação, que se inicia no estágio HH 4 (18 h de incubação) e se desenrola até aproximadamente o estágio HH 31 (7 dias de incubação), devido principalmente a transparência do embrião, o que facilita na percepção das mudanças que acontecem rapidamente de um estágio para o próximo (Dias, 1996). 


\section{OBJETIVO}

\subsection{Objetivo Geral}

Estudar a expressão temporal e espacial do produto do gene FoxN1 em estágios iniciais do desenvolvimento e em jovens adultos de G. gallus e também verificar a participação deste gene na morfologia de estruturas/órgãos de M. musculus jovens por meio da comparação entre indivíduos selvagens, heterozigotos e homozigotos recessivos Foxn1-/ou Nude.

\subsection{Objetivos Específicos}

I. Identificação e análise inicial in silico de sequências correspondentes ao gene e proteína da subclasse FoxN em G.gallus;

II. Isolamento e caracterização genômica e transcricional do homólogo putativo de FoxN1 identificados pela análise in silico;

III. Análise da expressão temporal de FoxN1 nos estágios iniciais de desenvolvimento embrionário de G. gallus, por meio de qPCR, e em diferentes órgãos (timo, coração, cérebro e músculo) de jovens adultos;

IV. Análise da expressão espacial de FoxN1 por meio de imunofluorescência de embriões de G. gallus em estágios iniciais do desenvolvimento;

V. Avaliação morfológica de órgãos (cérebro, coração, fígado, pulmão, rins e baço) de $M$. musculus homozigotos recessivos para Foxn1, heterozigotos e selvagens, por meio de comparação de peso e avaliação macroscópica;

VI. Avaliação morfológica do cérebro de M. musculus homozigotos recessivos para Foxn1, heterozigotos e selvagens, por meio de imagens de microtomografia;

VII. Caracterização da mutação e descrição fenotípica de um paciente com deleção parcial do gene FOXN1 em heterozigose, por meio da técnica de Chromossomal microarray ou Microarranjo Cromossômico (CMA). 


\section{MATERIAL E MÉTODOS}

\subsection{Animais}

Para o desenvolvimento desse projeto foram utilizados:

a) Embriões (ovos galados) de G. gallus em estágios iniciais de desenvolvimento, desde a formação da linha primitiva até o desenvolvimento das cinco vesículas encefálicas, segundo classificação descrita por Hamburger e Hamilton (1951 - reimpresso em 1992); provenientes da Granja AsaAlimentos S/A (Recanto das Emas - Distrito Federal). Os ovos galados foram incubados em incubadora IP-130 da empresa Premium Ecológica, a $37{ }^{\circ} \mathrm{C}, 55$ $\%$ de umidade e com giro a cada duas horas, por tempo correspondente a cada estágio.

b) Três indivíduos Juvenis de G. gallus, chocados a termo em incubadora Premium Ecológica IP-130, a $37^{\circ} \mathrm{C}, 55 \%$ de umidade e com giro a cada duas horas, ate o $19^{\circ}$ de incubação, e sem giro após este período até o $21^{\circ}$ dia (eclosão). Os pintinhos foram eutanasiados por overdose do anestésico (Cloridrato de Lidocaína 2\%) como preconizado pelo Comitê de Ética no Uso Animal.

c) Nove camundongos (M. musculus) fêmeas, nulíparas, da linhagem C57BL/6, sendo três selvagem (C57BL/6), três heterozigotas (C57BL/6 Nude +) e três homozigotas recessivas (C57BL/6 Nude), provenientes do Biotério de Criação de Camundongos Isogênicos do Instituto de Ciências Biomédicas da USP, com idade aproximada de 8 a 10 semanas. Os animais foram alojados em gaiolas de polipropileno com grade zincada e mantidos em estante refrigerada da Alesco ${ }^{\circledR}$, localizada no Alojamento de Animais do Departamento de Genética e Morfologia, no Instituto de Ciências Biológicas, da UnB, a temperatura de $23 \pm 2{ }^{\circ} \mathrm{C}$. Os animais foram submetidos a ciclo claro/escuro de $12 \mathrm{~h} / 12 \mathrm{~h}$. As instalações, condições ambientais, manejo e cuidados com os animais seguiram os padrões recomendados pelo Guide for the Care and Use of Laboratory Animals e em conformidade com a lei aplicável ao bem-estar animal referente ao uso e ao cuidado de animais de laboratório (Lei Federal Brasileira $\mathrm{N}^{\mathrm{o}} 11.794$ de 08 de Outubro de 2008). Antes da realização do experimento os animais passaram por um período de aclimatação de 15 dias. 
Os experimentos, tanto com G. gallus, quanto com M. musculus foram realizados após aprovação do projeto pelo Comitê de Ética no Uso de Animais (CEUA) do Instituto de Ciências Biológicas da Universidade de Brasília, referidos como UnBDoc número 78.202/2011 e 66.260/2013 (Anexo 2).

\subsection{Paciente}

Foi incluído neste estudo de um paciente atendido no Hospital Universitário de Brasília (HUB-UnB). O paciente passou por anamnese e exames clínicos realizados por médicas geneticistas do Ambulatório de Genética do HUB-UnB. Foram obtidas amostras de sangue periférico do paciente e de seus pais biológicos, em dois tubos, um com EDTA, para extração de DNA, e outro com heparina para obtenção de cultura temporária de células.

Os responsáveis legais pelo paciente concordaram em participar do estudo e assinaram Termo de Consentimento Livre e Esclarecido (Anexo 3), após esclarecimentos sobre procedimento de retirada e do destino da amostra de sangue, sendo exposta de forma acessível a questão do sigilo sobre a identificação do paciente, e ainda autorização para uso de fotos.

\subsection{Métodos}

\subsubsection{Estudo in silico dos produtos do gene FoxN1 em G. gallus}

O homólogo do gene FOXN1 de H. sapiens e de M. musculus em galinha ( $G$. gallus, XP_415816) foi selecionado a partir do banco de dados do National Center of Biotechnology Information (http://www.ncbi.nih.gov).

O perfil hidropático da proteína FoxN1 foi analisado por meio do algoritmo Kyte-Doolittle, através de um software disponível no sítio: http://gcat.davidson.edu/rakarnik/KD.htm.

A predição de possíveis hélices transmembranares na proteína foi explorada a partir do software TMHMM (http://www.cbs.dtu.dk/services/TMHMM/).

Os multialinhamentos foram realizados pelo software JALVIEW (http://www.jalview.org/download), Multalin (http://multalin.toulouse.inra.fr/multalin/) e a árvore filogenética, do tipo Rooted Phylogenetic Tree foi feita pelo auxílio do software CLUSTALW (http://www.genome.jp/tools/clustalw/). 
O parâmetro de cores usado no software JALVIEW foi do tipo ClustalX, em que cada resíduo dentro do alinhamento recebe uma cor de acordo com alguns critérios que cada aminoácido recebe da seguinte forma: resíduos hidrofóbicos (ACFHILMVWY), cor azul; resíduos carregados negativamente $(\mathrm{DE})$, cor magenta; resíduos carregados positivamente (KR), cor vermelha; resíduos polares (STQN), cor verde; resíduos de cisteínas, cor rosa; resíduos de glicinas, cor laranja; resíduos de prolinas, cor amarela; resíduos de aromáticos (FYW), ciano. O parâmetro de cores usado no software Multalin foi o BLOSUM62 score, em que os resíduos de aminoácidos são coloridos em concordância com seu valor de acordo com o padrão. Para o máximo escore, acima de $90 \%$ de similaridade, a cor do resíduo é vermelha e para o escore mínimo, acima de $50 \%$ de similaridade, a cor é a azul. Os resíduos neutros aparecem na cor preta. Também são usados os símbolos ! se os resíduos forem Isoleucina ou Valina; \$ se forem Leucina ou Metionina; \% se forem Fenilalanina ou Tirosina e; \# se forem Asparagina, Aspartato, Glutamina ou Glutamato.

\subsubsection{Coleta dos embriões de G. gallus}

Para o estudo de expressão por qPCR foram coletados embriões de cada estágio inicial do desenvolvimento de G. gallus. Para os estágios mais precoces: estágio $\mathrm{HH}$ 4, correspondente a 18 horas de incubação, estágio HH 6 correspondente a 24 horas de incubação e estágio HH 10, correspondente a 33 horas de incubação, foram realizados pools de cinco embriões por amostra. A partir do estágio HH 12 (48 horas de incubação) até o estágio HH 31 (7 dias de incubação), um único individuo foi utilizado por amostra.

Para a coleta dos embriões foi utilizado o protocolo descrito em Baroneza e colaboradores (2011), conforme o seguinte: os ovos foram limpos por fora com uma solução de álcool $70 \%$. Em seguida, foram girados lentamente algumas vezes para que as membranas no interior que prendem o embrião à casca se soltassem. Com o auxílio de uma seringa de 5

$\mathrm{ml}$, a câmara de ar do ovo foi furada (com ângulo de $45^{\circ}$ para evitar encostar na gema) e mais ou menos $10 \mathrm{ml}$ de clara foi retirada. Abriu-se uma janela em cima do ovo com o auxílio de uma tesoura íris, para ter acesso ao embrião que se localiza acima da gema. Embriões com período de incubação superior a 3 dias foram coletados com o auxílio de uma colher de sobremesa de plástico. Para os embriões com período de incubação inferiores a 3 dias a coleta foi feita com o auxílio de papel de filtro, recortado na forma de um retângulo com medidas aproximadas de 1 x 0,5 cm, sendo que no interior foi recortada uma elipse, com raio menor de cerca de 0,2 - 0,3 cm (Figura 17). O papel filtro foi posicionado em cima do embrião, que 
ficava aderido ao centro. A membrana vitelínica ao redor do papel foi recortada com o auxílio de uma tesoura íris de ponta fina e o embrião foi retirado. Logo após o procedimento de coleta, os embriões foram separados por estágios e guardados sozinhos ou em grupos, em tubos eppendorfs de 1,5 $\mathrm{ml}$ e tão logo congelados em nitrogênio líquido e guardados em freezer $-80{ }^{\circ} \mathrm{C}$ para posterior extração do RNA.

Para o estudo da expressão gênica de FoxN1 em indivíduo juvenil, uma vez eutanasiados, foi efetuada laparotomia e coleta de alguns órgãos abdominais (coração, músculo e timo) e cérebro. Os órgãos foram rapidamente congelados em nitrogênio liquido para posterior extração de RNA.

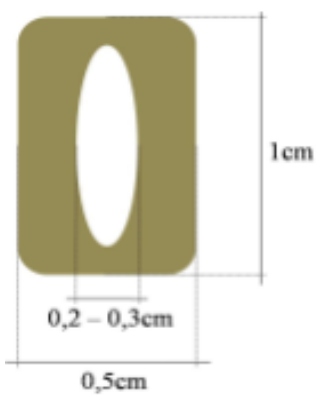

Figura 17. Modelo de preparação de papel de filtro utilizado para coleta de embriões de galinha com período de incubação inferior a 3 dias. (Retirado de Baroneza, 2009).

\subsubsection{Extração de RNA}

A extração de RNA dos embriões de G. gallus foi realizada de duas maneiras, a depender da quantidade de amostra biológica coletada: para os embriões de estágio HH 4 até HH 12 foi utilizado o kit de extração Illustra RNAspin Mini Kit (GE Healthcare Life Science) seguindo o protocolo do fabricante. Para os demais estágios, HH 17 (60 horas), HH 20 (72 horas), HH 24 (4 dias), HH 27 (5 dias), HH 29 (6 dias), HH 31 (7 dias) e órgãos de aves recém eclodidas, a extração de RNA foi feita com o reagente TRIZOL®, seguindo o seguinte protocolo: todo o procedimento foi realizado em utensílios e equipamentos previamente limpos com água oxigenada a $3 \%$ ou SDS $0,5 \%$, enxaguados com agua MilliQ contendo $0,1 \%$ de DEPC seguidos por dupla autoclavagem seguidos de fornagem a $90{ }^{\circ} \mathrm{C}$ overnight. Acrescentou-se $1 \mathrm{ml}$ de TRIZOL $®$ para cada $100 \mathrm{mg}$ de amostra a ser macerada em um tubo falcon de vidro. Em seguida as amostras foram homogeneizadas com o equipamento TURRAX (T-10, IKA®) e transferidas para um tubo eppendorf de $1,5 \mathrm{ml}$ e mantidas no gelo, seguido por um período de incubação a temperatura ambiente por $5 \mathrm{~min}$. As 
amostras foram centrifugadas a $4{ }^{\circ} \mathrm{C}$, por $10 \mathrm{~min}$ a $14000 \mathrm{RPM}$ (Eppendorf $5430 \mathrm{R}$ ) e o sobrenadante foi então transferido para um novo tubo eppendorf de $1,5 \mathrm{ml}$ em que acrescentou-se TRIZOL $®$ até completar $1 \mathrm{ml}$ e repetiram-se o tempo de incubação em temperatura ambiente e a centrifugação seguinte. O sobrenadante, novamente, foi então transferido um novo tubo onde foram acrescentados $200 \mu \mathrm{l}$ de Clorofórmio gelado. As amostras foram homogeneizadas em vórtex (Vortex Mixer, Labnet International, Inc.) por 15 segundos e incubados por 3 min a temperatura ambiente. As amostras foram centrifugadas por 15 min, a $4{ }^{\circ} \mathrm{C}$ a 14000 RPM e foi verificada a formação de três fases visíveis: uma inferior rosa (DNA), uma intermediária branca (Proteínas) e uma superior incolor (RNA). Transferiuse cuidadosamente a fase incolor para um novo eppendorf e nele foram acrescentados $500 \mu 1$ de Isopropanol absoluto gelado em cada amostra. As amostras foram homogeneizadas em vórtex por mais 15 segundos e incubadas por $10 \mathrm{~min}$ a temperatura ambiente, seguida de centrifugação por 10 min a $4{ }^{\circ} \mathrm{C}$ a 14000 RPM. O sobrenadante foi descartado, e a secagem do pellet feita ao ar. $1 \mathrm{ml}$ de etanol $75 \%$ gelado foi acrescentado em cada amostra, agitadas no vórtex por mais 15 segundos e centrifugadas por 5 min a $4{ }^{\circ} \mathrm{C}$, a 9000 RPM. O sobrenadante foi descartado e a secagem do pellet feita ao ar. As amostras foram ressuspendidas com $50 \mu$ água DEPC 1 \%. Por fim, as amostras foram rapidamente congeladas em nitrogênio líquido e guardadas adequadamente em freezer $-80{ }^{\circ} \mathrm{C}$ (U535, Innova ${ }^{\circledR}$, New Brunswick).

Um total de $3 \mu 1$ de RNA total foram utilizados para quantificação em equipamento Qubit® 2.0 seguindo orientações do fabricante. As amostras foram guardadas em freezer - 80 ${ }^{\circ} \mathrm{C}$ ou verificadas sua integridade em eletroforese com gel de agarose $1,2 \%$ em condições desnaturantes (MOPS 0,2 M, EDTA 0,01 M, NaAc anidro 0,05 $\mathrm{M} \mathrm{H}_{2} 0$ DEPC 2x autoclavada).

\subsubsection{Preparo do cDNA total}

Para cada amostra, $1 \mu \mathrm{g}$ de RNA total foi utilizado para produzir cDNA, etapa essencial para análise de expressão (qPCR). O cDNA foi produzido utilizando o kit High Capacity cDNA Reverse Transcription Kit (1000 reactions) da empresa Applied biosystems ${ }^{\circledR}$ seguindo as orientações do fabricante.

Para reação de transcriptase reversa, as amostras foram colocadas em tubos eppendorfs de 0,2 ml, em termociclador Veriti 96 Well Thermal Cycler (Applied Biosystems $\left.{ }^{\circledR}\right)$, com ciclo sugerido pelo fabricante do kit, a saber: primeiro passo de 
anelamento dos primers a $25{ }^{\circ} \mathrm{C}$, por $10 \mathrm{~min}$; seguidos de um período de elongação a $37{ }^{\circ} \mathrm{C}$, por $120 \mathrm{~min}$, e inativação da enzima a $85^{\circ} \mathrm{C}$, por $5 \mathrm{~min}$. Uma vez a reação finalizada, os cDNAs foram guardados em freezer a $-20{ }^{\circ} \mathrm{C}$ para uso posterior.

\subsection{5. qPCR}

A fim de analisar a expressão do gene de interesse nas amostras coletadas, foi realizada uma qPCR (StepOne Real time PCR system, Applied Biosystems@) a partir do cDNA produzido. Foram utilizadas sondas e primers específicos (TaqMan®) desenhados na região domínio forkhead de FoxN1 para G. gallus. O ensaio Taqman® foi construído com o auxílio do software PrimerExpress ${ }^{\circledR}$ v.2.0. A sonda corresponde à sequência: 5'-CAA AGC CAG AAG AGC- 3' (VIC/MGB-NFQ) e os primers GGFoxn1F (foward) - 5' - CCA GTG GCT GTG AGG AAG AGT A - 3'; GGFoxn1R (reverse) - 5' - TGT CGC CTA TCA GCG TGT CA - 3'. O gene constitutivo utilizado foi o GAPDH de G. gallus adquirido pela empresa Life Technologies $^{\text {TM }}$ sob o nome Gg 03346982_m1 (FAM/MGB-NFQ).

Para a análise com os estágios de desenvolvimento de G. gallus (HH 4 - HH 31) foi utilizado o estágio de $\mathrm{HH}-4(18 \mathrm{~h})$ como calibrador por apresentar a taxa mais reprimida de expressão do gene FoxN1 entre todas as amostras. Para a análise dos órgãos de indivíduos juvenis foi utilizado o timo como amostra calibradora, por apresentar expressão já conhecida.

Além de triplicatas biológicas, foram efetuadas em todas as amostras, triplicatas técnicas e foi feita a média e desvio padrão nos resultados.

\subsubsection{Imunofluorescência de embriões de G. gallus}

Para visualização da expressão espacial de FoxN1 em embriões G. gallus de estágios iniciais de desenvolvimento, foi efetuada a marcação por imunofluorescência, como descrito a seguir: os embriões coletados foram lavados com solução fisiológica e o excesso de membranas extraembrionárias dos embriões maiores que HH 20 (72 h) foi retirado. Estes embriões foram fixados em solução de paraformaldeído a $4 \%$ por 20 min em temperatura ambiente para permitir a retirada total das membranas extraembrionárias. Embriões no estágio HH 12 (48 h) e em diante tiveram o tubo neural e coração perfurados com agulha epidérmica para permitir o acesso do anticorpo. Os embriões foram então transferidos para tubos eppendorfs de $2 \mathrm{ml}$ (previamente autoclavados), com solução de PBTD (PBS 1x, 1 \% DMSO, $1 \%$ Triton-X100). A quantidade de embriões em cada tubo variou de um a cinco a depender 
do estágio. Os embriões passaram por três lavagens de 20 min cada em PBTD, em agitador orbital. Logo após as lavagens, os embriões foram incubados em solução de bloqueio (PBTD $+5 \%$ de soro de cavalo) por $3 \mathrm{~h}$, em agitador orbital. A imunomarcação foi feita a partir de solução do anticorpo primário feito em humanos (FOXN1 - G 20 - Santa Cruz Biotechnologie, Inc.) em diluição 1:250 com a solução do bloqueio incubado por 36 horas a 4 ${ }^{\circ} \mathrm{C}$ em agitador orbital. Após a incubação as amostras foram lavadas em PBTD durante de 30 min. Esta etapa foi repetida cinco vezes. Os embriões foram então incubados no escuro com uma solução do anticorpo secundário (anti-goat IgG-FITC- Santa Cruz Biotechnologie, Inc.) em diluição 1:200 com solução de bloqueio por três horas em temperatura ambiente. Após a incubação as amostras foram lavadas em PBTD durante de $30 \mathrm{~min}$. Esta etapa foi repetida cinco vezes. Os embriões foram então posicionados em lâminas histológicas, recobertos por lamínula e analisados em microscópio multifocal. A fluorescência foi detectada por excitação com luz UV a 450 - $490 \mathrm{~nm}$ (FITC) num aumento 40X. As fotos foram tiradas com o auxílio do microscópio multifocal Axioskop 2 (Zeiss) e do software ZEN 2011 Blue Edition (Zeiss).

\subsubsection{Coleta de órgãos de camundongos}

Após eutanásia por exposição ao $\mathrm{CO}_{2}$, foi efetuada a laparotomia e coleta dos seguintes órgãos abdominais: coração, fígado, pulmão, rins e baço, além dos cérebros dos camundongos. Para os órgãos abdominais, foi efetuada análise macroscópica e pesagem. Para os cérebros, foi efetuada inicialmente análise macroscópica e pesagem. Esses cérebros foram então fixados por $24 \mathrm{~h}$ em formalina $4 \%$ tamponada a $4{ }^{\circ} \mathrm{C}$ para análise posterior em microtomógrafo.

\subsubsection{Microtomografias}

Os cérebros de camundongos destinados às imagens morfológicas por microtomografia foram passados por banhos de álcoois em diferentes porcentagens por uma hora em cada gradiente começando por $70 \%, 80 \%, 90 \%$ e $100 \%$, para preservar as estruturas cerebrais. Em seguida, os órgãos foram colocados em uma solução de tintura de iodo a $1 \%$ (tintura de iodo $2 \%$ + álcool $100 \%$ na proporção $1: 1$ ) por $12 \mathrm{~h}$. As imagens foram feitas no equipamento SkyScan 1076 e analisadas pelo software CTVox (morfologia, planos de corte). 


\subsubsection{Extração de DNA de sangue do paciente e análise cromossômica por Chromosomal Microarray (CMA).}

Dez mililitros do sangue periférico do paciente e de seus pais foram coletados por punção venosa em tubos contendo ácido etileno diamina tetracético (EDTA). Após a coleta, foram realizadas extrações de DNA, utilizando o QIAamp ${ }^{\circledR}$ DNA Mini Kit (Qiagen) ou o IllustraTM blood genomicPrep Mini Spin Kit (GE Healthcare Life Science) seguindo todas as instruções dos fabricantes.

Para a análise cromossômica por chromosomal microarray (CMA), o DNA genômico (250 ng) extraído do paciente e de seus respectivos pais biológicos mais um controle negativo e um controle positivo (fornecido pelo fabricante), foi digerido pela enzima de restrição NspI, seguindo as recomendações do fabricante (Affymetrix). Depois de digeridas, as amostras foram ligadas a adaptadores e em seguida, um primer universal que reconhece a sequencia do adaptador ligado ao DNA genômico foi utilizado para amplificar as sequencias obtidas por meio de Reação de Cadeia em Polimerase (PCR). As condições da PCR foram otimizadas para amplificar preferencialmente fragmentos de $150-2.000 \mathrm{pb}$ de comprimento, que foram confirmados posteriormente em gel de agarose a $2 \%$ em TBE $1 X$.

$\mathrm{Na}$ sequencia estes produtos foram purificados utilizando beads magnéticas e quantificados no espectrofotômetro NanoVue PlusTM (GE Healthcare Life Science). O passo seguinte foi a fragmentação das amostras purificadas em $50-200$ pb, que em seguida foram confirmados em um gel de agarose a $4 \%$ em TBE $1 X$, a um campo elétrico com voltagem constante de $10 \mathrm{~V} / \mathrm{cm}$, por $1 \mathrm{~h}$.

Os fragmentos de DNA com 50 - 200 pb foram revelados pela coloração do gel em solução de brometo de etídeo $(5 \mathrm{mg} / \mathrm{mL})$. Posteriormente, a imagem foi capturada utilizando o sistema de vídeo-documentação/ImageMaster ${ }^{\circledR}$ (VDS - Video-documentation System) (Pharmacia Biotech.). Seguindo o protocolo, os fragmentos de DNA foram marcados por terminal com deoxynucleotidyl transferase e então aplicados no Affymetrix GeneChip ${ }^{\circledR}$ e hibridados por $16-18$ horas a $50{ }^{\circ} \mathrm{C}$ e 60 RPM no GeneChip ${ }^{\circledR}$ Hybridization Oven 645 (Affymetrix). Os chips foram então lavados e corados na GeneChip ${ }^{\circledR}$ Fluidic Station 450 (Affymetrix) e escaneados no GeneChip ${ }^{\circledR}$ Scanner 3000 7G (Affymetrix) operados pelo Affymetrix GeneChip ${ }^{\circledR}$ Command Console (AGCC, Versão 3.2.2). A partir daí foram gerados arquivos ".CEL" que foram convertidos em ".CYCHP” para serem lidos e analisados no Affymetrix ${ }^{\circledR}$ Chromosome Analysis Suite (ChAS) 2.0 software. 


\subsubsection{Análise estatística dos dados obtidos}

Os resultados obtidos de qPCR de estágios de desenvolvimento de G. gallus e dos órgãos destes; análise de pesos dos órgãos dos camundongos e das medidas dos cérebros destes foram validados por análise estatística com teste de normalidade (Shapiro-Wilk) e teste de variância simples, ANOVA One Way, em que os dados se mostravam significativos quando apresentavam o valor de $\mathrm{p} \leq 0,05$. Todos as análises de cálculos, como médias e desvio padrão foram feitos por meio do software EXCEL 2011. 


\section{RESULTADOS}

\subsection{Análise in silico de FoxN1}

A estrutura do gene FoxN1 da espécie G. gallus apresenta oito regiões codificantes ou éxons, uma região promotora e outra terminadora não transcritas. A proteína codificada por esse gene contém 653 resíduos de aminoácidos. Suas propriedades transcricionais se devem substancialmente a presença de dois domínios específicos: o domínio $f k h$, responsável pela ligação da proteína ao DNA e um domínio regulatório, chamado de domínio de ativação (que em outras proteínas forkhead pode ter papel repressor) por ser responsável por ativar a transcrição da sequência a qual FoxN1 é sinalizado a se ligar.

O domínio $f k h$ é codificado pelos quarto, quinto e sexto éxons da sequência do gene, e o domínio de ativação é codificado pelos éxons subsequentes, ou seja, o sétimo e o oitavo, como se pode ver na Figura 18.

\section{FOXN1}

Gallus gallus

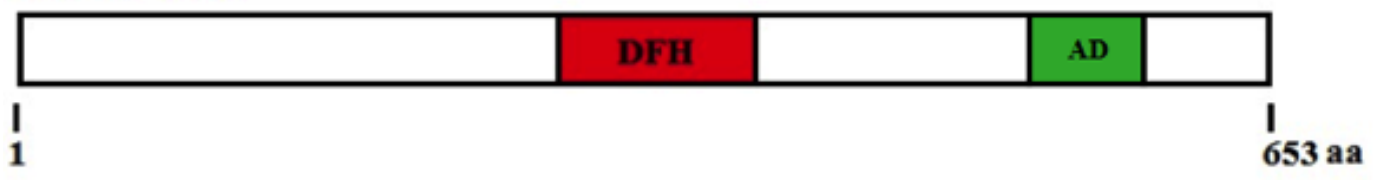

FoxN1

Gallus gallus

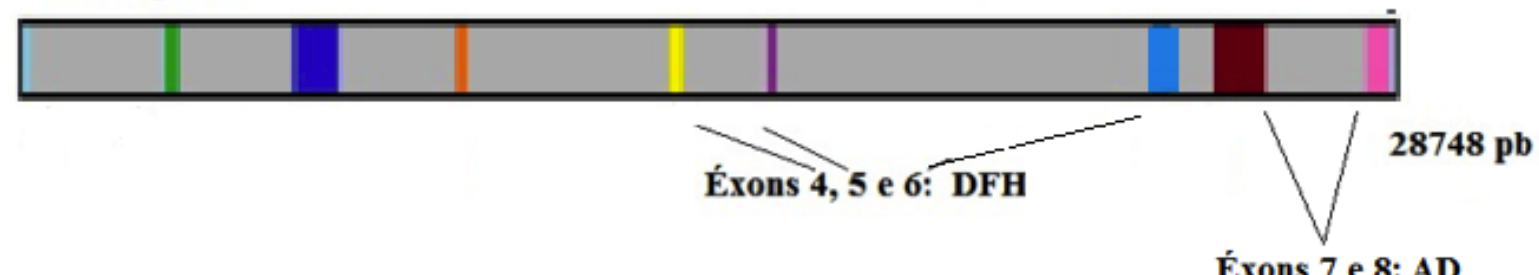

Figura 18. Representação da estrutura da proteína e do gene FoxN1 de G. gallus respectivamente. Acima, tem-se a estrutura da proteína FoxN1, onde DFH representa a localização do domínio forkhead desta, que inclui os aminoácidos localizados nas posições 285 - 382 e, AD corresponde ao local do domínio de ativação na proteína, incluindo os resíduos de aminoácidos localizados nas posições 532 - 587. Abaixo, tem-se a estrutura do gene FoxN1, apresentando, pela cor azul-claro, as regiões promotoras (extremidade esquerda e próxima a ela) e a região terminadora (extremidade direita); os oito éxons desenhados conforme dado retirado do sítio NCBI (Ensembl:ENSGALG00000003654); as regiões em cor cinza representam as regiões não codificantes do gene, os íntrons. Os éxons que codificam o domínio forkhead são o quarto, quinto e o sexto do gene e os que codificam o domínio de ativação são o sétimo e o oitavo. 
O domínio de ativação está frequentemente ausente nas mutações descritas na literatura para esse gene levando ao fenótipo já conhecido. Antes, acreditava-se que a ausência do domínio de ligação seria a causa principal do fenótipo nude, mas um estudo realizado em 1996, por Schuddekopf e colaboradores, mostrou que na maioria dessas mutações não estava presente também o domínio de ativação. Ademais, mostrou que em um outro alelo mutante para FoxN1 em R. novergicus (alelo rnu) havia uma mutação do tipo nonsense no oitavo éxon, o que acarretava a formação de uma proteína truncada que apresentava o domínio $f k h$ mas não o domínio de ativação. Mesmo assim, o fenótipo típico nude estava presente mostrando que esse domínio é essencial para a função da proteína descrita.

A sequência da proteína FoxN1 do organismo estudado não apresenta regiões transmembrana, contendo apenas domínios ou hélices extramembranares, como mostra o diagrama construído a partir do software TMHMM na Figura 19. Essa estrutura corrobora com a estrutura de um fator de transcrição, o qual permanece no citoplasma celular e passa pelos poros da membrana nuclear quando é requisitado.

Essa proteína também apresenta mais regiões hidrofílicas que hidrofóbicas, estas sendo encontradas mais proximamente na região do domínio fkh (Figura 20) ou também do domínio de ligação ao ligante, o qual normalmente é hidrofóbico. Esse dado também corrobora a observação anterior, já que FoxN1 não apresenta regiões transmembrana, sendo uma proteína citosólica.

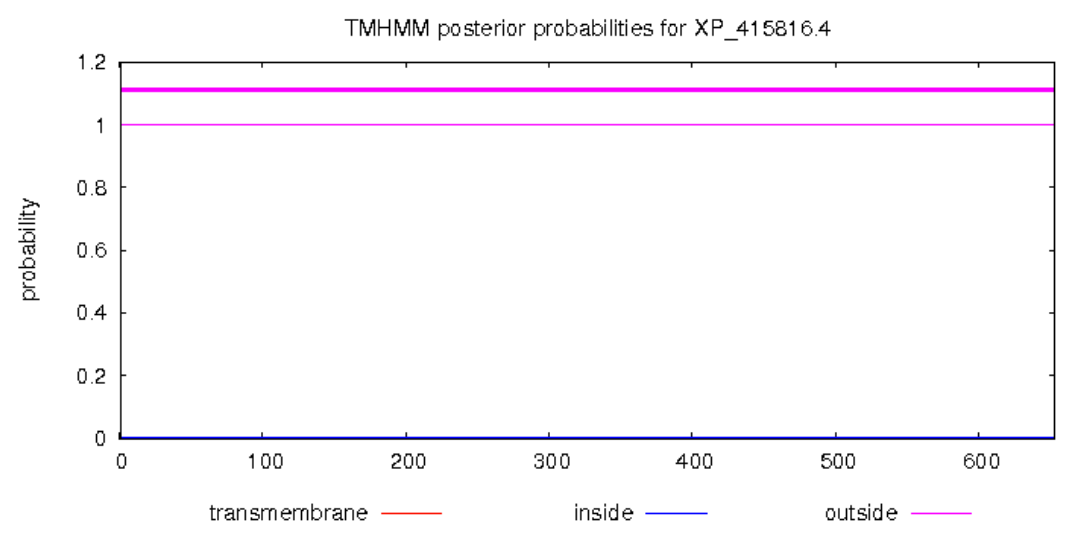

Figura 19. Diagrama construído por meio do software TMHMM (http://www.cbs.dtu.dk/services/TMHMM/) que mostra a estrutura da sequência de resíduos de aminoácidos de FoxN1 de G. gallus (NCBI XP_415816.4). O diagrama mostra que essa estrutura apresenta somente regiões extra membranares (em rosa). 


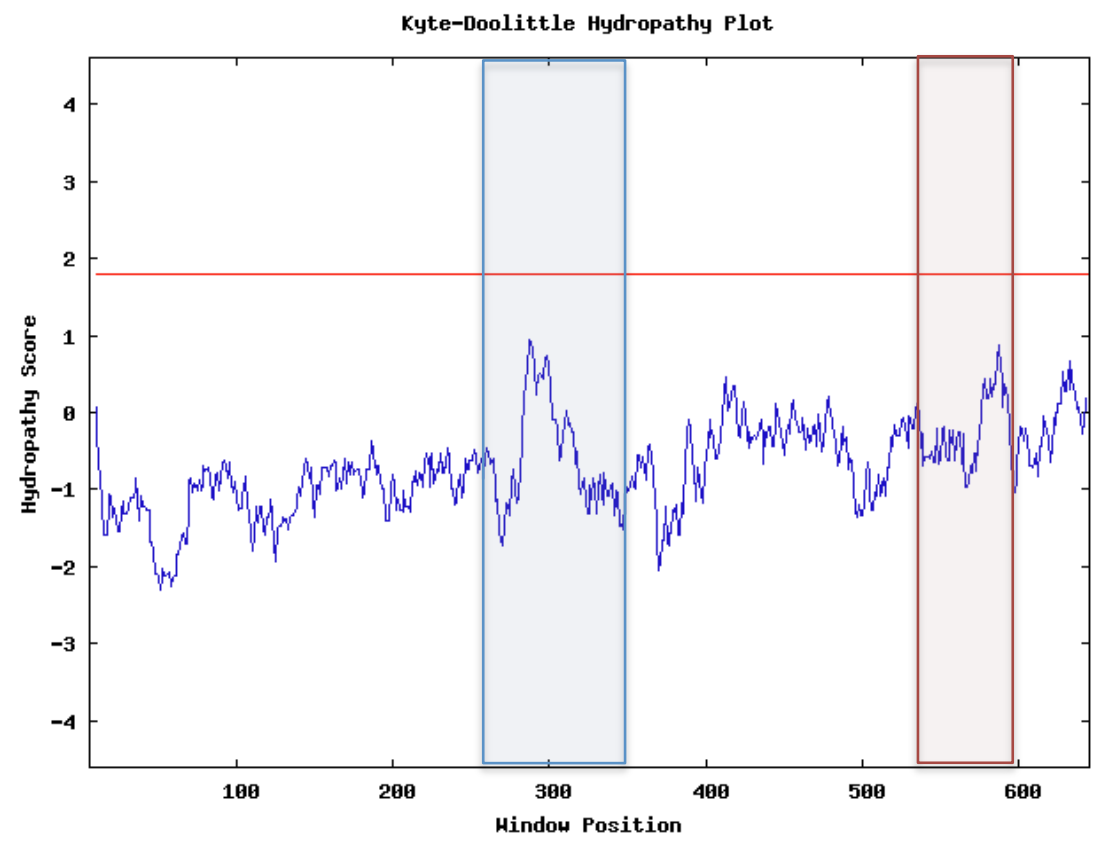

Figura 20. Diagrama de hidrofobicidade da proteína FoxN1 de G. gallus segundo a escala de Kyte-Doollitle (http://gcat.davidson.edu/DGPB/kd/kyte-doolittle.htm). A figura mostra uma predominância de regiões hidrofílicas (pontos negativos) e uma região mais hidrofóbica (pontos positivos) na região do domínio $f k h$ (retângulo azul) e uma segunda região com pico positivo, correspondente à região do domínio de ativação (retângulo vermelho).

O alinhamento feito com as sequências de aminoácidos de FoxN1 de algumas espécies com o auxílio do software Jalview, revelou uma sequência consenso para a proteína e, novamente evidenciou a presença de uma região altamente conservada que consiste na região do domínio $f k h$ (Figura 21) e outra região conservada, representando o domínio de ativação (Figura 22).

O alinhamento feito com todas as proteínas forkhead presentes em G. gallus mostrou que a única região que apresenta maior similaridade entre elas é a região do domínio forkhead, como já era esperado (Figura 23). A maioria das sequências apresentadas na Fig. 23, começa com a sequência consenso de resíduos KPPY, como FoxN2 e FoxA1. Dentre as sequências de aminoácidos correspondentes às proteínas da subclasse FoxN em G. gallus, FoxN1 e FoxN4, apresentaram maior similaridade que FoxN2 e FoxN3 (Figura 24). Isso sugere uma divergência na evolução filogenética dessa subclasse.

FoxN1 e FoxN4 estão ambos envolvidos na diferenciação celular durante o desenvolvimento embrionário (Hannenhaalli e Kaestner, 2009). FoxN1 age na diferenciação dos folículos capilares e nas células epiteliais do timo e FoxN4 está envolvido na 
diferenciação das células amácrinas e horizontais durante a formação da retina em camundongos (Li et al., 2004). Também está envolvido na especificação dos interneurônios na região ventral da espinha dorsal e é essencial para a formação do canal átrio-ventricular no desenvolvimento do coração em D. rerio (zebrafish) (Chi et al., 2008).

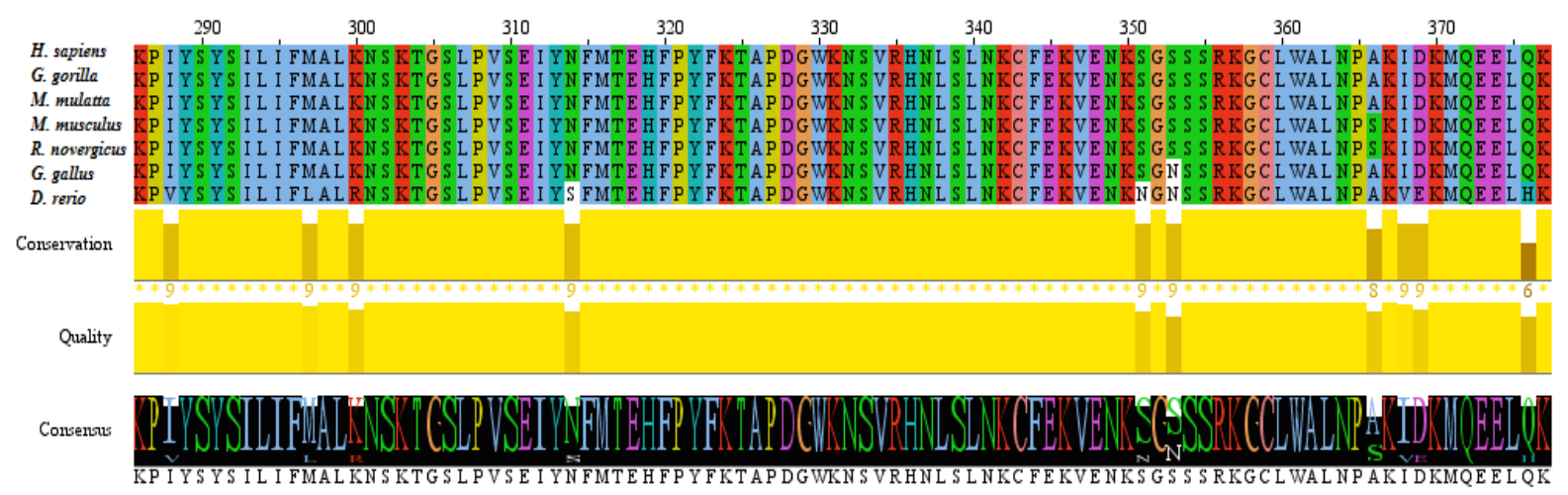

Figura 21. Resultado do alinhamento - feito pelo software Jalview - das sequências de aminoácidos de FoxN1 das espécies H. sapiens (gi: 18201913), G. gorilla (gi: 426348868), Macaca mulatta (gi: 109113734), M. musculus (gi: 148683621), R. norvergicus (gi: 154816166), G. gallus (gi: 513215825) e D. Rerio (gi: 47086885). O resultado mostra uma sequência consenso para a proteína para uma região altamente conservada, o domínio forkhead, presente nos resíduos de aminoácidos localizados aproximadamente nas posições 285 - 382 . Também é possível estabelecer a localização do domínio de ativação nessas espécies, como uma segunda região relativamente conservada aproximadamente entre os aminoácidos 536 - 590. O código de cor dos aminoácidos é baseado nas propriedades físico-químicas providas pelo programa Jalview e todos os parâmetros usados foram os padronizados também pelo programa.

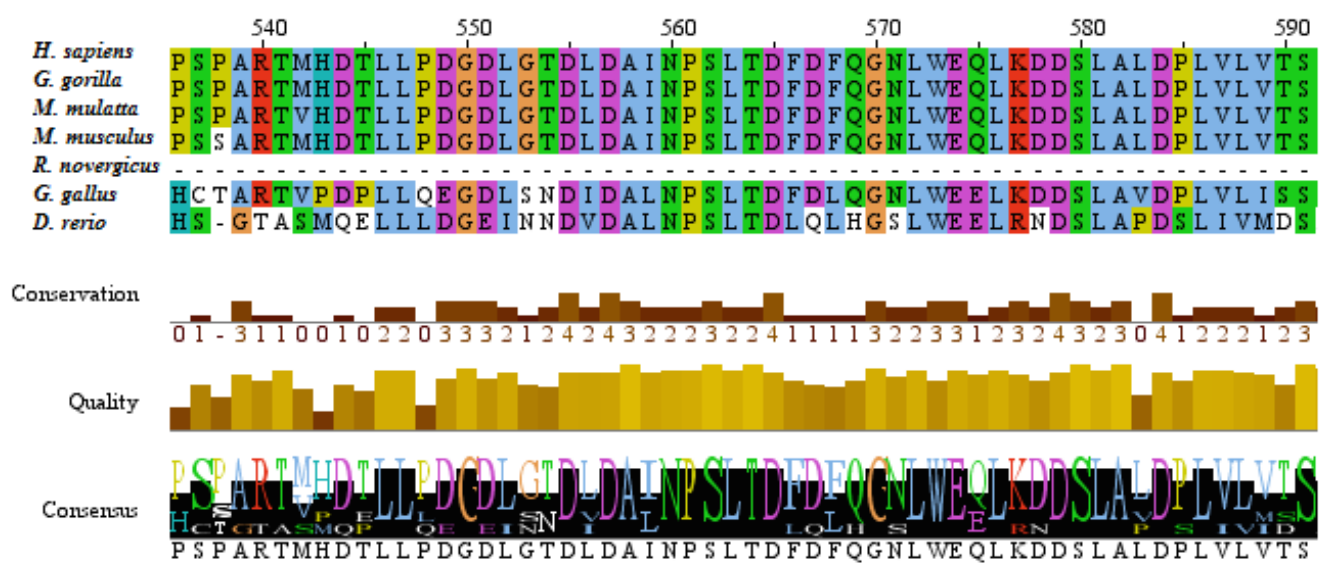

Figura 22. Resultado do alinhamento - feito pelo software Jalview - das sequências de aminoácidos de FoxN1 das espécies H. sapiens (gi: 18201913), G. gorilla (gi: 426348868), Macaca mulatta (gi: 109113734), M. musculus (gi: 148683621), R. norvergicus (gi: 154816166), G. gallus (gi: 513215825) e D. Rerio (gi: 47086885). O resultado mostra uma sequência consenso para a proteína para uma região conservada, o domínio de ativação nessas espécies, aproximadamente entre os aminoácidos 536 - 590. O código de cor dos aminoácidos é baseado nas propriedades físico-químicas providas pelo programa Jalview e todos os parâmetros usados foram os padronizados também pelo programa. 


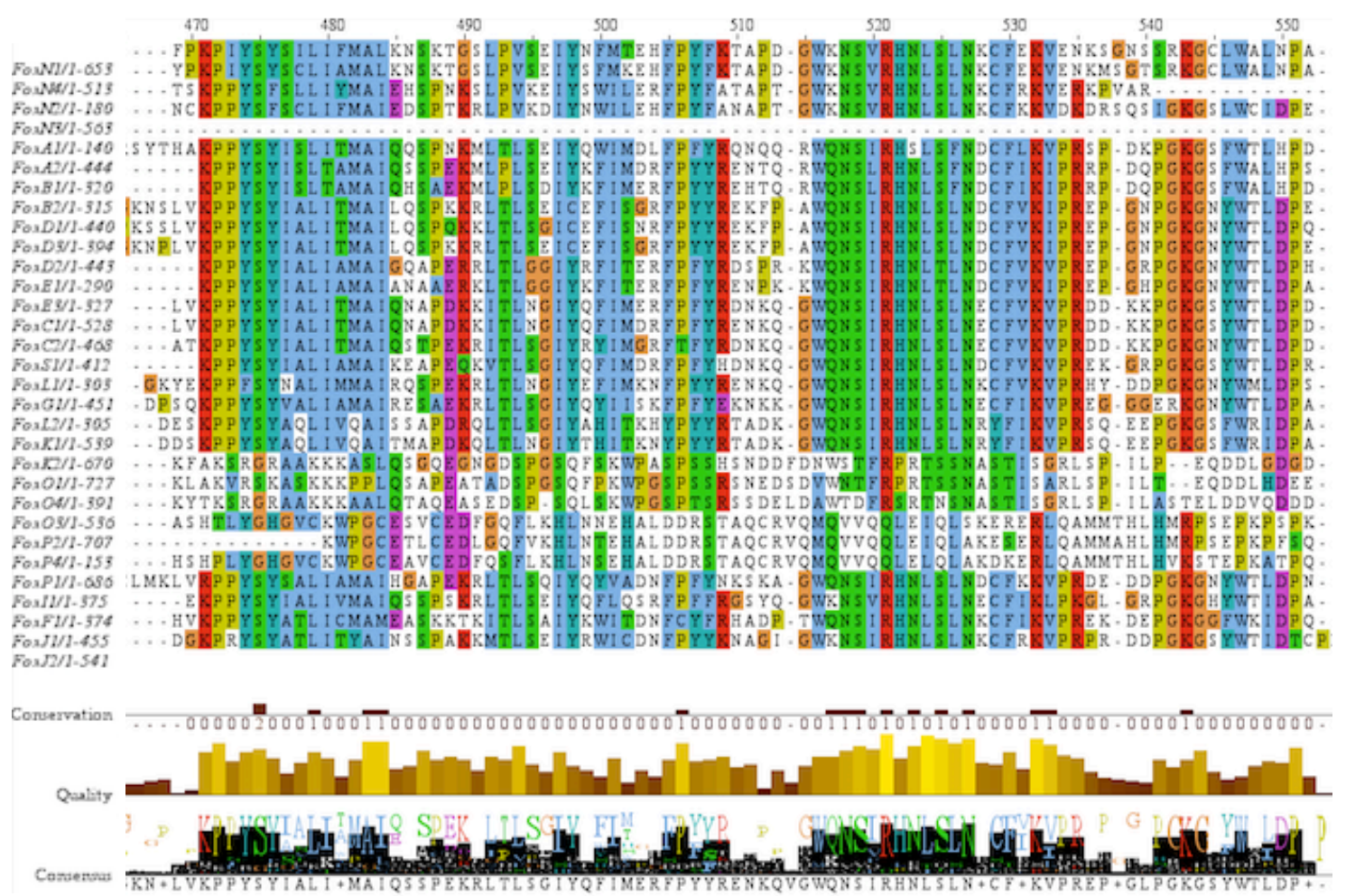

Figura 23. Alinhamento das sequências de aminoácidos das proteínas Fox encontradas na espécie G. gallus feito pelo software Jalview. A figura mostra a região do domínio forkhead de todas as sequências e apresenta a sequência consenso para tal. O código de cor dos aminoácidos é baseado nas propriedades físico-químicas providas pelo programa Jalview e todos os parâmetros usados foram os padronizados também pelo programa.

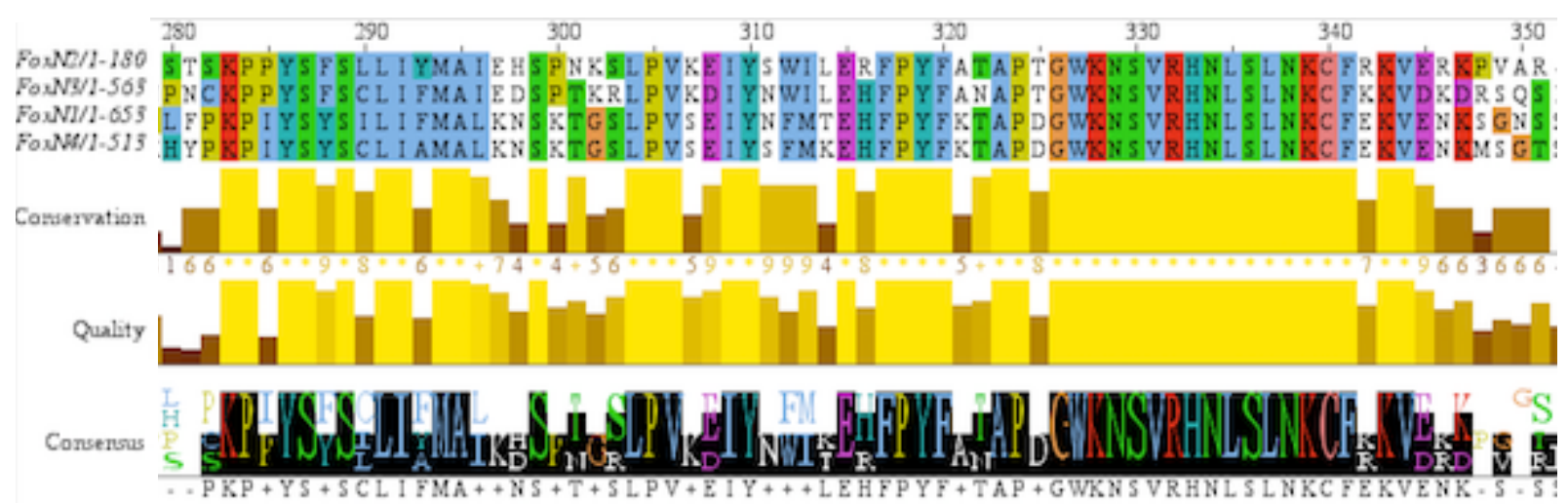

Figura 24. Alinhamento das sequências de aminoácidos das proteínas da subclasse FoxN encontradas na espécie G. gallus feito pelo software Jalview. A figura mostra a região do domínio forkhead destas sequências e apresenta sua sequência consenso. Nota-se que FoxN1 e FoxN4 são mais próximas entre si do que quando comparadas com FoxN2 e FoxN3, cuja similaridade entre si também é maior. O código de cor dos aminoácidos é baseado nas propriedades físico-químicas providas pelo programa Jalview e todos os parâmetros usados foram os padronizados também pelo programa. 
A árvore filogenética construída por meio do software CLUSTALW também corrobora com essa afirmação, pois apresenta FoxN1 e FoxN4 como sequências irmãs e de origem mais antiga que FoxN2 e N3, que apresentam ancestrais mais recentes, como pode ser visto na Figura 25.

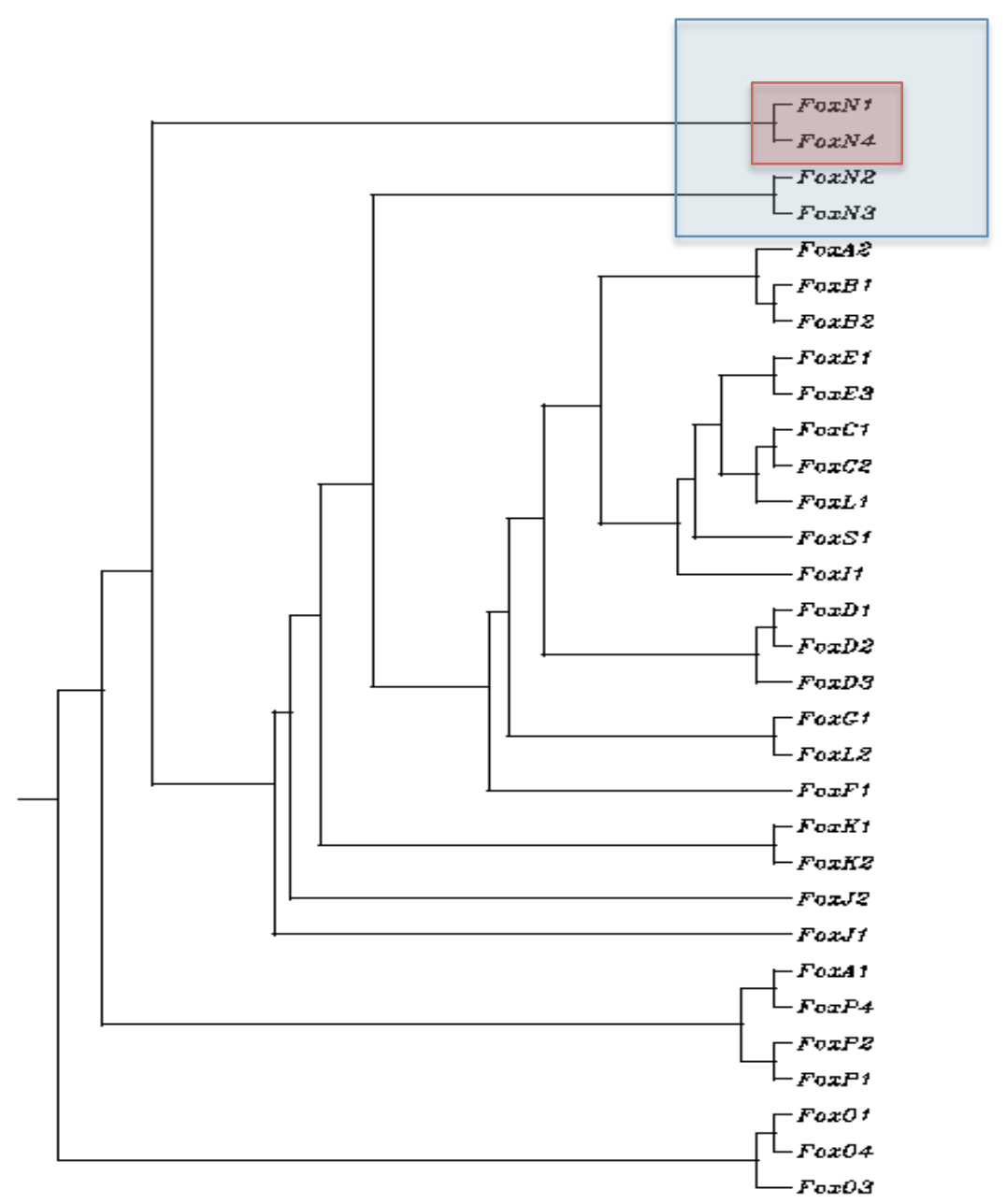

Figura 25. Árvore filogenética baseada nas sequências de aminoácidos das proteínas Fox de G. gallus construída com auxílio do software CLUSTALW. A figura mostra que FoxN1 e FoxN4 são proteínas irmãs (retângulo vermelho) e que elas divergiram que FoxN2 e FoxN3 (retângulo verde), que apresentam ancestrais mais recentes. Todos os parâmetros usados foram de acordo com o padronizado pelo software CLUSTALW. 
A análise por qPCR dos estágios embrionários selecionados de G. gallus foi baseada no tipo de quantificação $\Delta \Delta \mathrm{Cq}$, que compara uma amostra a qual se conhece a expressão do gene em teste, HH 4/timo, e compara essa expressão a de um gene constitutivo, GAPDH, para a espécie em cada amostra. A Figura 26 mostra os estágios escolhidos assim como uma breve descrição das estruturas formadas em cada estágio.

O resultado obtido mostra que houve amplificação de FoxN1 nos embriões de $G$. gallus desde o estágio primordial de $18 \mathrm{~h}(\mathrm{HH} 4)$ até o ultimo estágio investigado, de sete dias (HH 31 ) de forma crescente: 1,$0734 ; 1,9431 ; 2,0175 ; 1,9499 ; 4,9034 ; 3,0023 ; 4,4087 ; 9,8549$; 8,7104 (Cabeça); 18,7140 (Corpo); 19,8000 (Cabeça); e 23,1122 (Corpo). (Figura 27).

Estudos de expressão em órgãos de indivíduos jovens mostraram uma expressão importante deste gene no timo (Figura 28) corroborando vários estudos (Albuquerque et al., 2002; Bleul et al., 2006; Cheng et al., 2009; Dooley et al., 2005), inclusive Darnell et al., 2014. Não foi detectado, em nosso estudo expressão no cérebro do jovem adulto (Fig. 28), apesar de Amorosi e colaboradores (2008), através hibridização in situ em cortes histológicos de cérebro de camundongo terem visualizado expressão deste gene no plexo coróide.

O timo se forma no terceiro arco faríngeo, e sua endoderme se separa da faringe por volta do quinto dia de incubação no embrião de galinha (Le Douarin e Jotereau, 1975). Sendo assim, nossos resultados estão alinhados com aqueles descritos por Darnell e colaboradores (2014) no que diz respeito a expressão no primórdio do timo. Porém, espera-se que esta diferenciação celular das células da crista neural seja paulatina e que a expressão de genes envolvidos no desenvolvimento de estruturas específicas comece em estágios precedentes e perdure até a formação completa da estrutura, e muitas vezes participando da função da estrutura no adulto, como é o caso de FoxN1 no timo e na pele. A Fig. 28, mostra a expressão de FoxN1 em órgãos de indivíduos jovens, sendo eles o cérebro $(3,0844)$, coração $(4,0558)$, o músculo peitoral $(0,9881)$ e o timo $(12517,3999)$. 


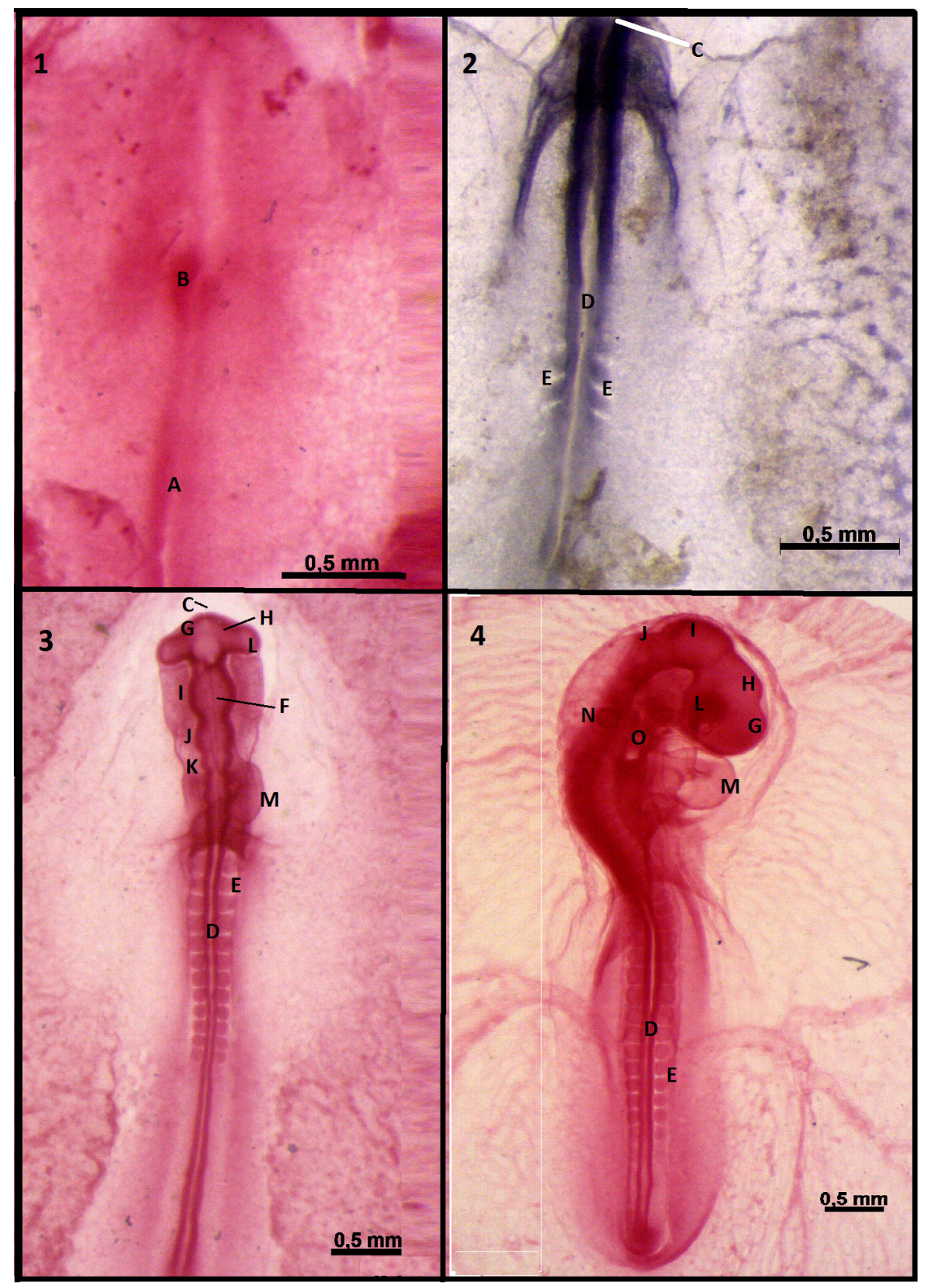

Figura 26. Imagens de embriões de galinha em diferentes estágios, sendo 1, HH 4 (18 h); 2, HH 6 (24 h); 3, HH 10 (33 h); 4, HH 12 (48 h), 5, HH 17 (60 h); 6, HH 20 (72 h); 7, HH 24 (4 dias); 8, HH 27 (5 dias); 9 , HH 29 (6 dias) e 10, HH 31 (7 dias). Algumas das estruturas em formação são mostradas. A barra de escala é de 0,5 mm para algumas das imagens, para as outras não foi possível conhecer a escala). A: Linha primitiva; B: Nó de Hensen; C: Neuróporo superior; D: Tubo neural; E: Somitos; F: Notocorda; G: Telencéfalo; H: Diencéfalo. I: Mesencéfalo; J: Metencéfalo; K: Mielencéfalo; L: Vesícula óptica/olho; M: Coração; N: Vesículo ótica; O: Arcos Faríngeos; P: Broto da Asa; Q: Broto de membro inferior; R: Alantóide; S: Epífise; T: Cauda. As figuras 5 e 6 foram retiradas de http://biology.clc.uc.edu/ fankhauser/Labs/Anatomy_\&_Physiology/A\&P202/Brain_ Development/embryo_15x_PC271481md_labeled.JPG; A figura $7, \quad$ foi retirada do sítio http://www.gopixpic.com/350/stock-photo-414135015*com|WI|223|4141|PreviewComp|SuperStock_4141 35015* jpg/; A figura 9 foi retirada do sítio https://www.flickr.com/photos/egosumdaniel/305095824/?rb=1; A figura 9 foi retirada do sítio https://www.youtube.com/watch?v=ljzBWzXE6G0; e a figura 10 foi retirada do sítio http://www.bioon.com.cn/protocol/showarticle.asp?newsid=19027. Todas as outras são fotos próprias. 


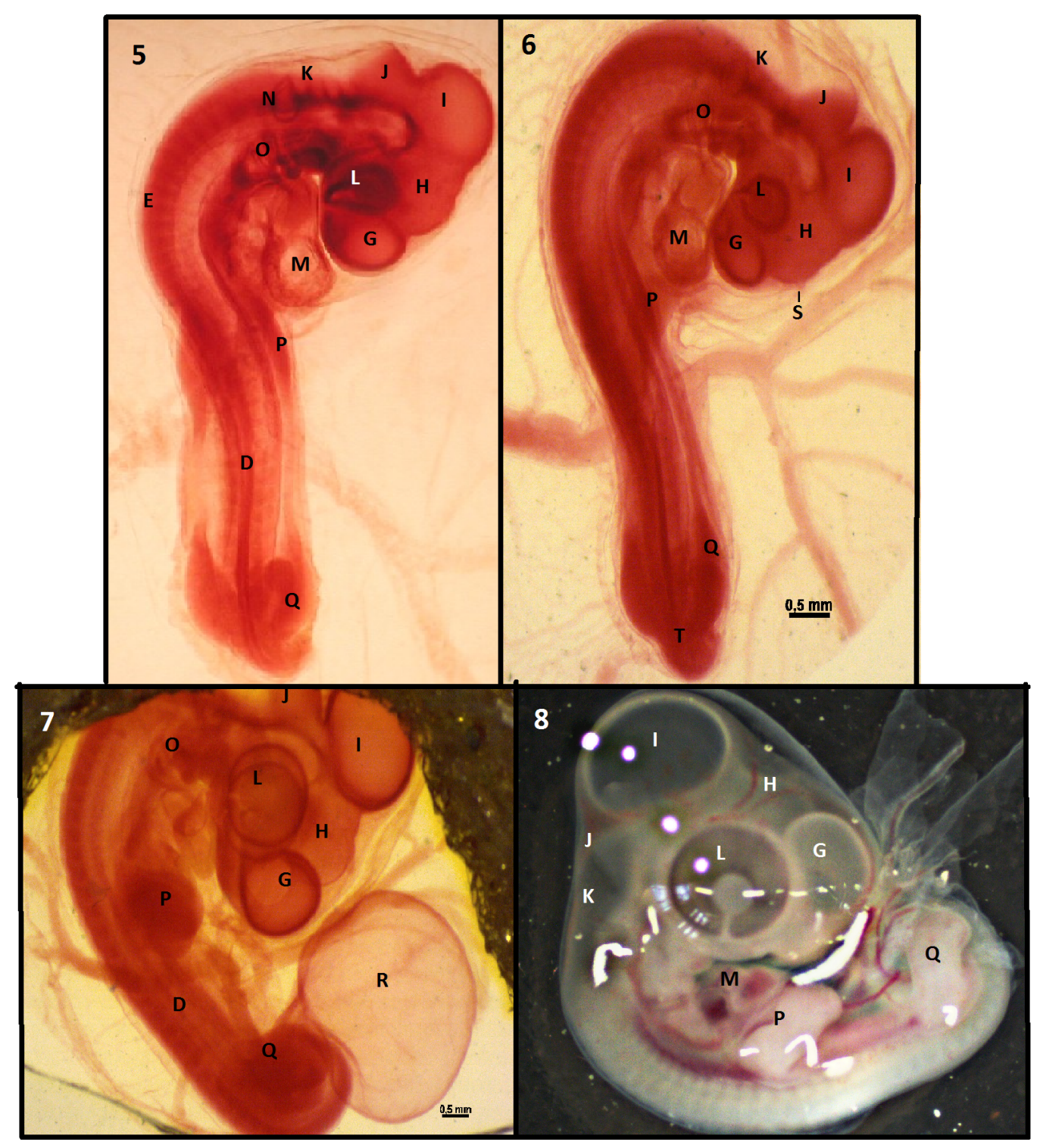

Figura 26. Continuação. 


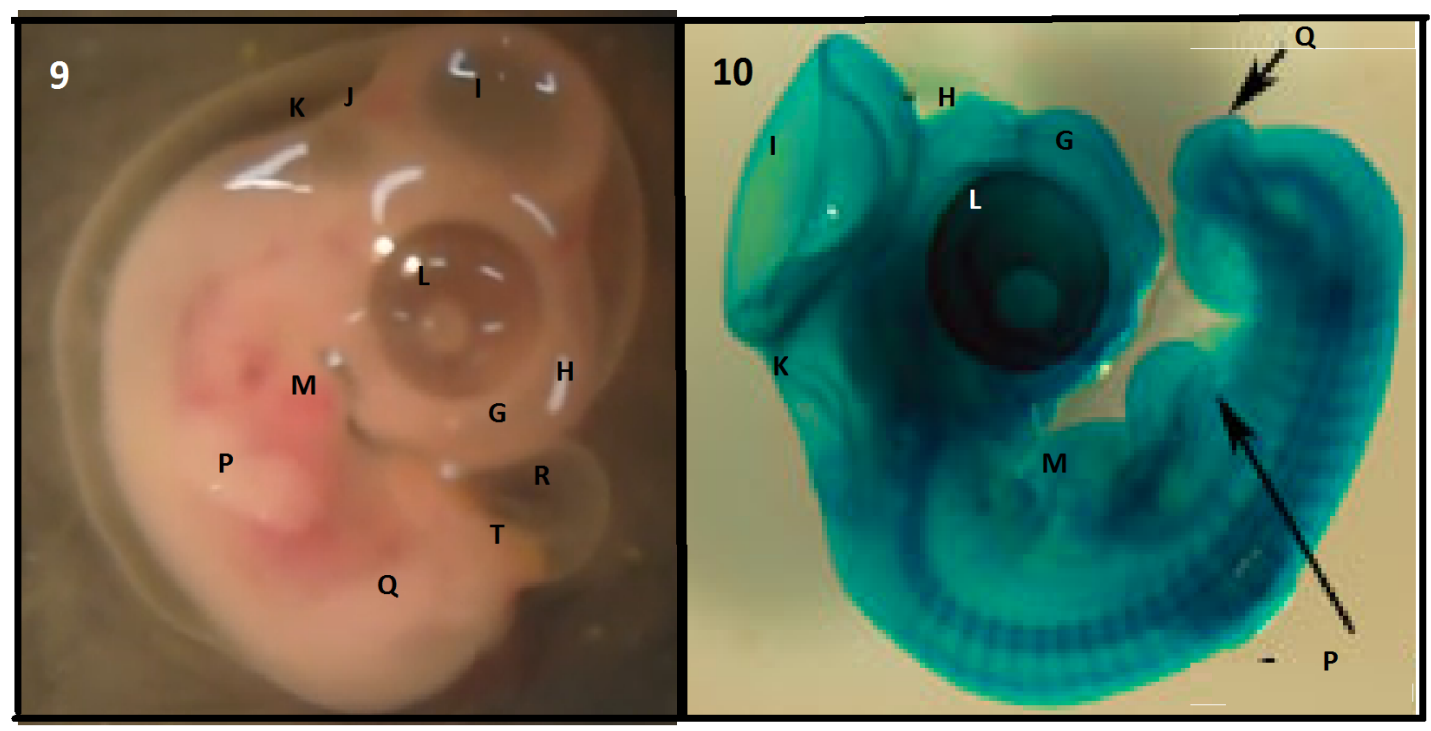

Figura 26. Continuação.

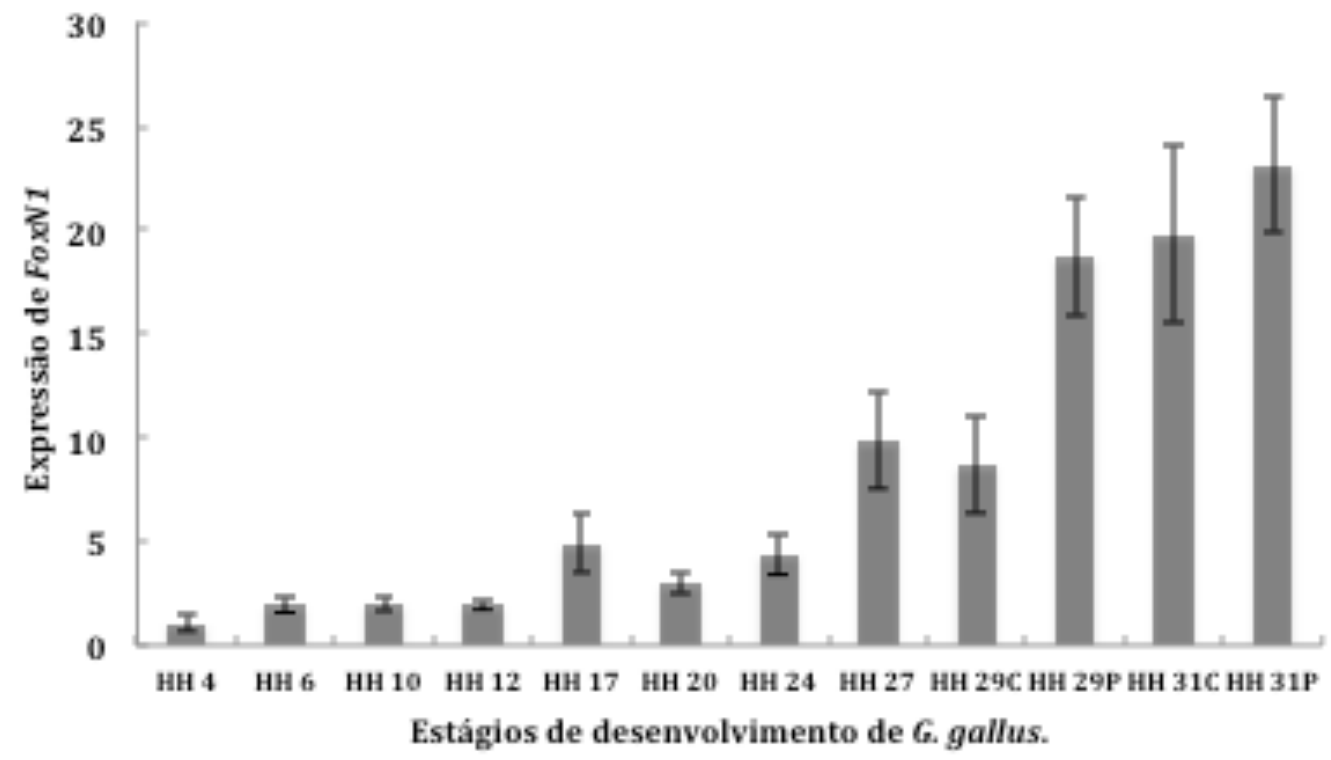

Figura 27. Análise da expressão de FoxN1 nos estágios de desenvolvimento de G. gallus. Os estágios HH $4-$ HH 20 (18-72) estão em horas de incubação e HH 24 - HH 31 (4-7) em dias de incubação. Nos embriões HH 4 , HH 6, HH 10 foram utilizadas amostras que continham um pool de RNA de cinco embriões por amostra. Foram feitas amostras em triplicata biológica e em triplicata técnica. A expressão aumenta à medida que o tempo de desenvolvimento também é maior. Os resultados foram obtidos por análise comparativa $\Delta \Delta \mathrm{Cq}$ pela plataforma ExpressionSuite Software v1.0.3. C = cabeça, $\mathrm{P}=$ corpo. 


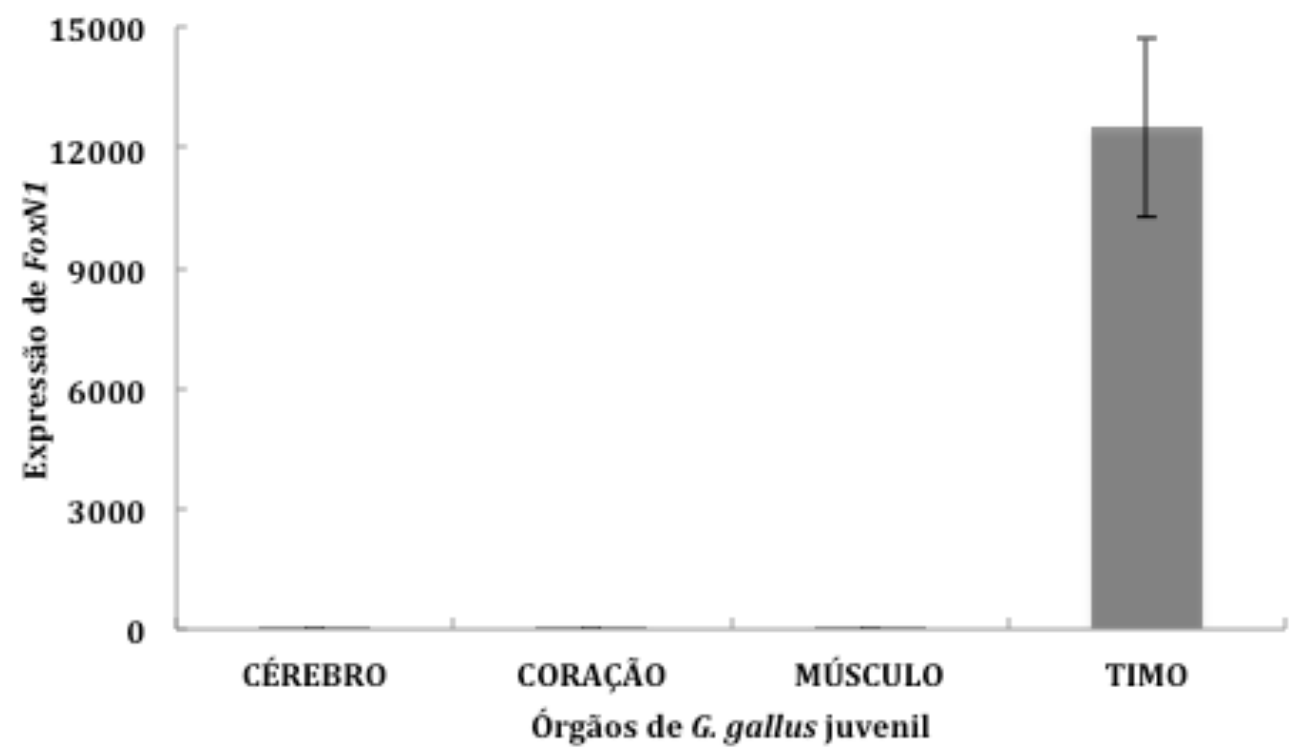

Figura 28. Análise da expressão de FoxN1 nos órgãos coletados de recém-nascidos, 21 dias, sendo eles o cérebro, o coração, o músculo peitoral e o timo. Foram feitas amostras em triplicata biológica e em triplicata técnica. A expressão dos demais órgãos quando comparada à do timo é ínfima. Os resultados foram obtidos por análise comparativa $\Delta \Delta$ Cq pela plataforma ExpressionSuite Software v1.0.3.

5.3. Imunofluorescência dos embriões de G. gallus.

Com o intuito de investigar a expressão espacial de FoxN1, foi feita a imunofluorescência usando anticorpo contra a proteína FoxN1. O anticorpo usado, FOXN1 G-20 (Santa Cruz Biotechnology, Inc.) foi produzido a partir de clone contendo sequencia humana de FoxN1 (Figura 29), porém possui reação cruzada com FoxN1 de outras espécies (informação do fornecedor).

Os dados preliminares obtidos pela imunofluorescência em embrião no estágio HH 12 (48 horas), mostram reatividade na região dos arcos faríngeos (Figura 30 e 31). Estes resultados corroboram os descritos por Darnell e colaboradores (2014).

A investigação espacial da expressão de FoxN1 foi efetuada em outros estágios, porém devido a difícil manipulação dos embriões em estágios muito iniciais, não foi possível comparar as amostras positivas com controles, logo estas não foram colocadas nesta dissertação. 


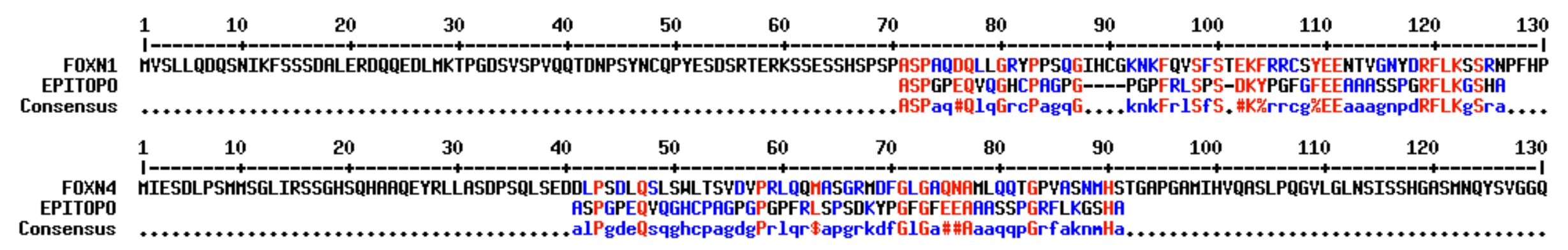

Figura 29. Alinhamento das sequencias de FoxN1 e de FoxN4 de G. gallus com a predita região do epítopo do anticorpo FOXN1 G-20 (Santa Cruz Biotechnologies, Inc. feita utilizando a sequência de FOXN1 humano como modelo base. Pode-se perceber que há semelhança entre as sequencias tanto de FoxN1 quanto de FoxN4 de G. gallus. Alinhamento feito com o auxílio do software Multalin, disponível no sítio http://multalin.toulouse.inra.fr/multalin/. 


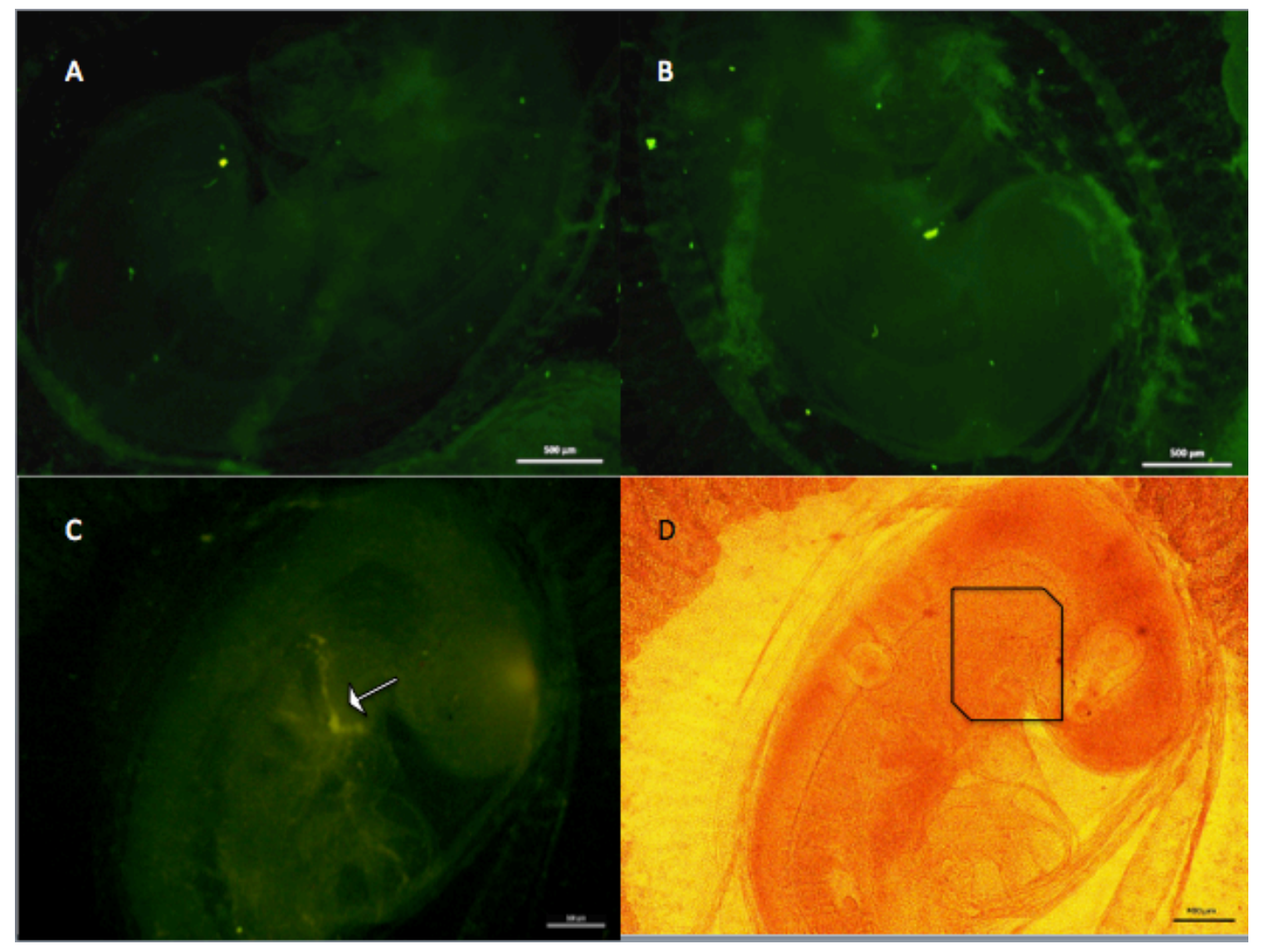

Figura 30. Imagens de imunofluorescência de um embrião de 48-50 h (HH 12). A e B representam os controles negativo e somente com anticorpo secundário, respectivamente. C, mostra um traço de expressão de FoxN1 na região dos arcos faríngeos (seta). $\mathrm{D}$, imagem de fase da mesma foto $\mathrm{C}$ mostra a região dos arcos faríngeos delimitada pelo retângulo e mostra que não há membranas extraembrionárias que possam ter prejudicado a imunomarcação na região encontrada. As imagens foram obtidas pelo software ZEN 2011 Blue Edition (Zeiss). A barra de escala das imagens é de $500 \mu \mathrm{m}$. 


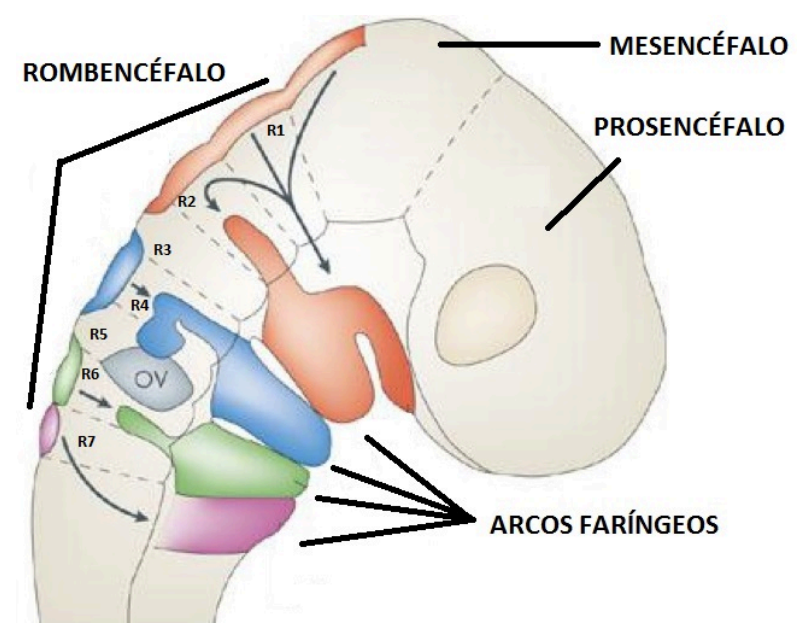

Figura 31. Esquema representando um embrião HH 12 (48 h) com algumas estruturas apontadas. As células da crista neural que migram a partir de parte do mesencéfalo e dos rombômeros 1 e 2 (R1 e R2) formam o mesênquima do primeiro arco faríngeo, em vermelho. As células da crista que partem dos rombômeros 3,4 e 5 (R3, R4 e R5) formam o mesênquima do segundo arco faríngeo, em azul. As células da crista que partem dos rombômeros 5 e 6 (R5 e R6) formam o mesênquima do terceiro arco faríngeo, em verde. As células da crista que migram do sétimo rombômero (R7) formam o mesênquima do quarto arco faríngeo, em rosa. OV - vesícula ótica. Figura retirada de Guthrie (2007).

5.4. Comparação anatômica e por microtomografia de cérebros de Mus musculus (C57BL/6).

Amorosi e colaboradores, em 2008, visualizaram a expressão de Foxn1 no plexo coróide de camundongo adulto. Este grupo sugeriu que Foxn1 poderia participar na formação do líquido cefalorraquidiano. O líquido cefalorraquidiano é gerado por filtrações através dos capilares coróides e posterior secreção; também propicia transporte ativo bidirecional de substâncias pelas células epiteliais coróides (Redzic et al., 2005). O líquido preenche o espaço subaracnóideono cérebro e medula espinhal (entre as meninges aracnóide e pia-máter) e atua como um amortecedor para o córtex cerebral e a medula espinhal (Redzic et al., 2005).

Com o intuito de verificar se os homozigotos recessivos (Nude), possuíam plexo coróide e /ou alguma modificação no cérebro, o peso comparativo (Figura 32), uma análise macroscópica (Figura 33) e uma comparação medidas dos cérebros (Tabela 1) foram efetuadas num primeiro momento. Isso foi seguido por análise por microtomografia comparativa do cérebro dos animais selvagens, heterozigotos e homozigotos para a mutação (Figura 34, 35 e 36).

$\mathrm{O}$ peso dos animais foi medido logo após a eutanásia por câmara de gás com $\mathrm{CO}_{2}$ e o mesmo aconteceu com cada órgão coletado, que foram: cérebro, coração, pulmão, rim esquerdo e direito e baço. Após fazer a normalização do peso do órgão do animal com o peso 
do mesmo, e tirar a média aritmética dos três animais de cada grupo, viu-se que os valores não são significativamente diferentes entre os três grupos, como é mostrado na Fig. 33.

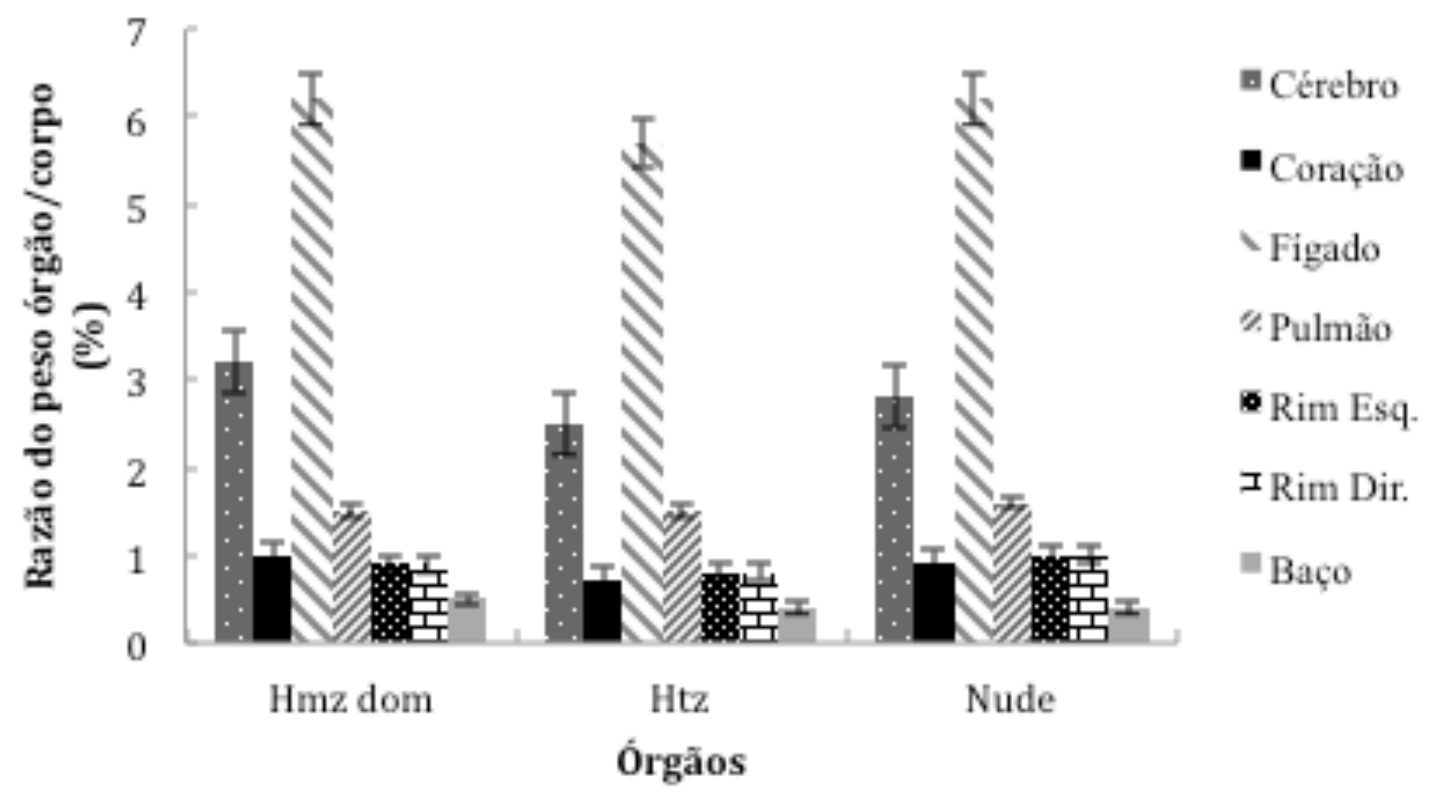

Figura 32. Gráfico da razão peso do órgão/peso do corpo de cada grupo em referencia aos órgãos: cérebro, coração, fígado, pulmão, rins e baço. $\mathrm{O}$ primeiro grupo corresponde a média aritmética dos três animais correspondentes ao grupo de selvagens (Hmz Dom); o segundo grupo corresponde a média aritmética dos três animais correspondentes ao grupo de Heterozigotos (Htz); e o terceiro grupo corresponde a média aritmética dos três animais correspondentes ao grupo de Homozigotos recessivos (Nude). Os valores no eixo das ordenadas correspondem à razão do peso do órgão/peso do corpo e em seguida foi feita a média aritmética desses valores em relação aos três animais de cada grupo. $\mathrm{p}>0,05$.

Em relação à comparação anatômica externa e superficial dos cérebros coletados também não foram observadas diferenças significativas entre os três grupos (Fig. 33), a não ser a visível diminuição do número de giros e sulcos no córtex dos camundongos Nude em relação aos outros dois grupos. Da mesma forma, em relação às medidas comparativas das dimensões do mesmo órgão, não houve diferença significativa como se pode ver em dados mostrados na Tab. 1. 


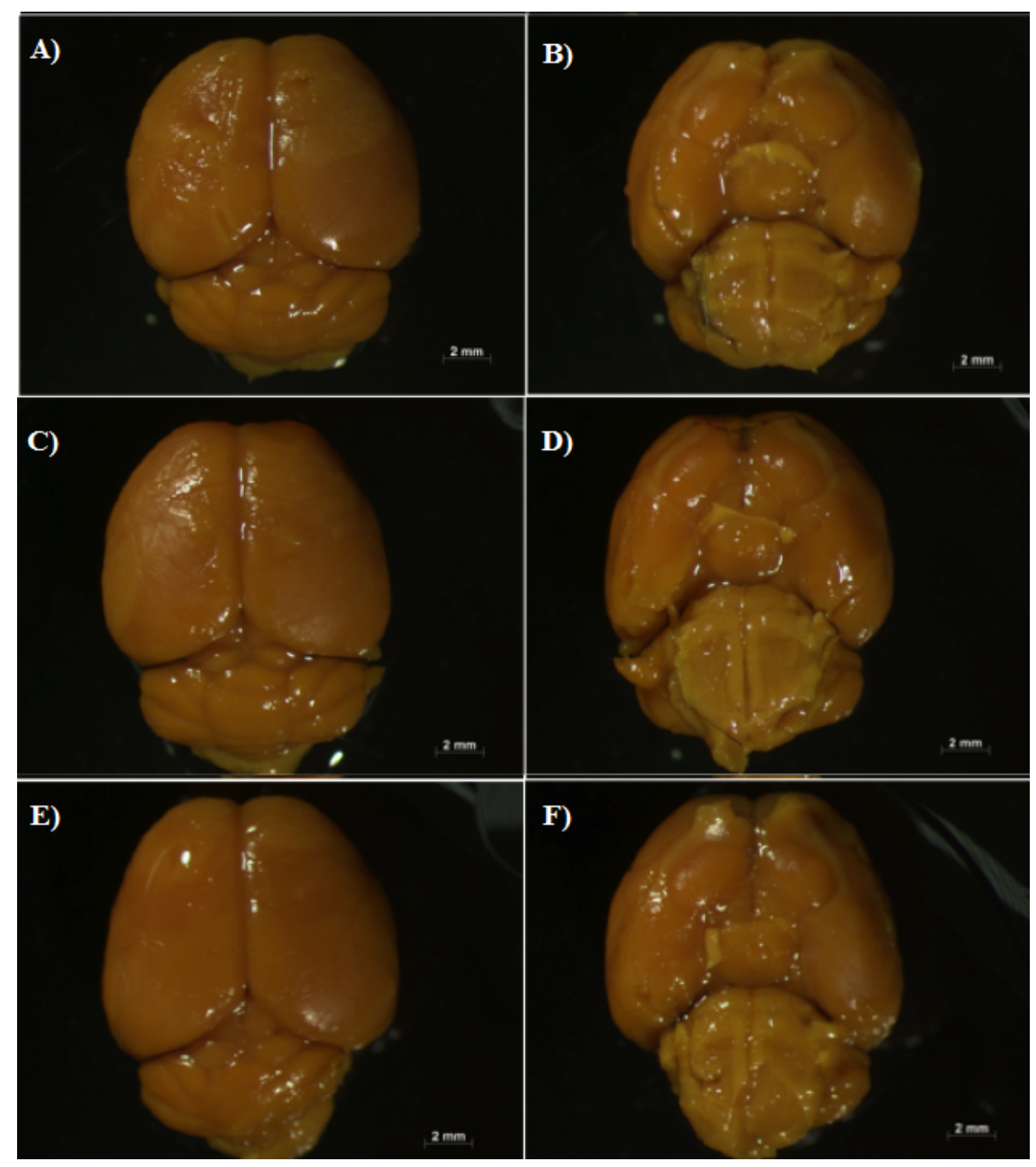

Figura 33. Fotografias dos cérebros coletados dos camundongos. As imagens do lado esquerdo mostram uma visão dorsal do órgão e as imagens do lado direito, o vista ventral. Os cérebros estavam fixados em álcool 100\% e coloridos com Iodo 1\%. As imagens A e B correspondem ao cérebro de camundongo do grupo selvagem; C e D, correspondem ao de camundongo do grupo Heterozigotos e; E e F, correspondem ao de camundongo do grupo Homozigotos recessivos. Pode-se perceber que não há diferenças visíveis significativas entre os grupos. Barra de escala $2 \mathrm{~mm}$. 
Tabela 1. Comparação das dimensões dos cérebros coletados dos três grupos de camundongos. Na tabela têm-se os valores das médias aritméticas $(\bar{x})$ dos três animais de cada grupo para as dimensões comprimento, largura e a área, todos em milímetros $(\mathrm{mm})$ e milímetros quadrados $\left(\mathrm{mm}^{2}\right)$ respectivamente. Também têm-se a relação dessas medidas pela razão dos grupos entre si em porcentagem (\%). Percebe-se que a variação é pequena, lembrando que os animais tinham diferença de idade de um mês e dois meses aproximadamente. $\mathrm{p}>0,05$.

\begin{tabular}{|c|c|c|c|c|c|c|}
\hline \multirow[t]{2}{*}{ Medidas $(\bar{x})$} & \multicolumn{3}{|c|}{ Grupos de animais } & \multicolumn{3}{|c|}{ Razão entre grupos (\%) } \\
\hline & S. & Htz. & Nude & Nude/S. & Nude/Htz & $\mathrm{Htz} / \mathrm{S}$. \\
\hline $\mathrm{C}(\mathrm{mm})$ & $11,63 \pm 0,99$ & $10,61 \pm 0,14$ & $10,72 \pm 0,29$ & 92 & 101 & 91 \\
\hline $\mathrm{L}(\mathrm{mm})$ & $13,07 \pm 0,97$ & $12,07 \pm 0,23$ & $12,02 \pm 0,28$ & 92 & 100 & 92 \\
\hline $\mathrm{A}\left(\mathrm{mm}^{2}\right)$ & $153,86 \pm 25,08$ & $128,10 \pm 1,9$ & $128,94 \pm 6,27$ & 84 & 101 & 83 \\
\hline
\end{tabular}

Com relação a análise feita por microtomografia dos cérebros dos mesmos animais, os dados mostraram que todos os animais de cada grupo apresentavam com nitidez os plexos coróides nas regiões dos ventrículos cerebrais: laterais, terceiro e, em algumas fotos, o quarto, como é possível ver nas figuras que se seguem (Fig. 34 a Fig. 36).

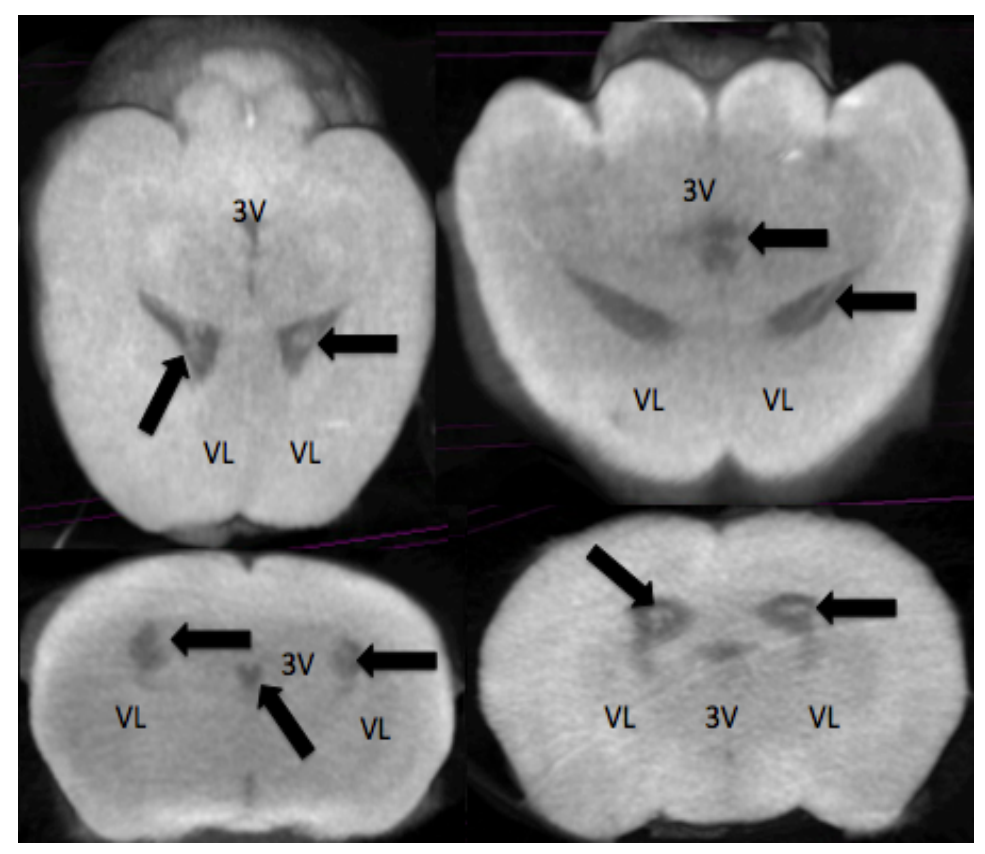

Figura 34. Fotomicrografia do cérebro de um dos camundongos selvagens. Na imagem é possível identificar a presença de plexo coróide nas regiões dos ventrículos laterais (VL) e no terceiro ventrículo (3V). As setas apontam o local onde está o plexo coróide. 


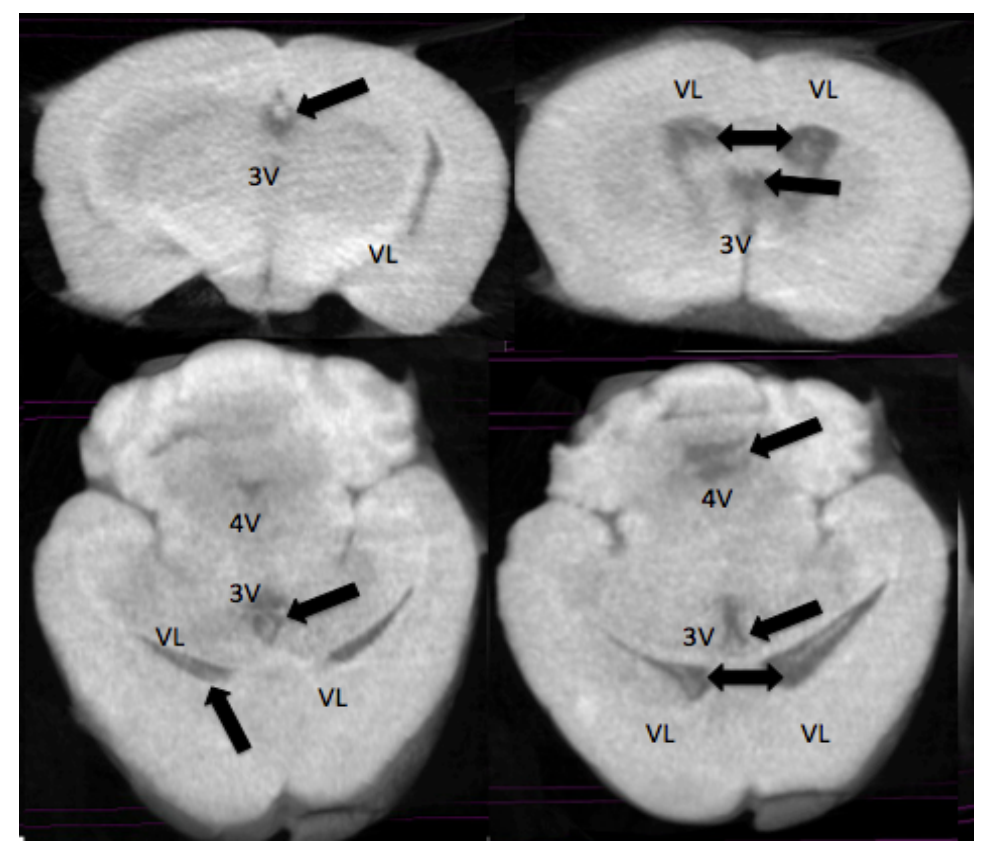

Figura 35. Fotomicrografia do cérebro de um dos camundongos Nude/+. Na imagem é possível identificar a presença de plexo coróide nas regiões dos ventrículos laterais (VL) no terceiro ventrículo (3V) e, também no quarto ventrículo (4V). As setas apontam o local onde está o plexo coróide.

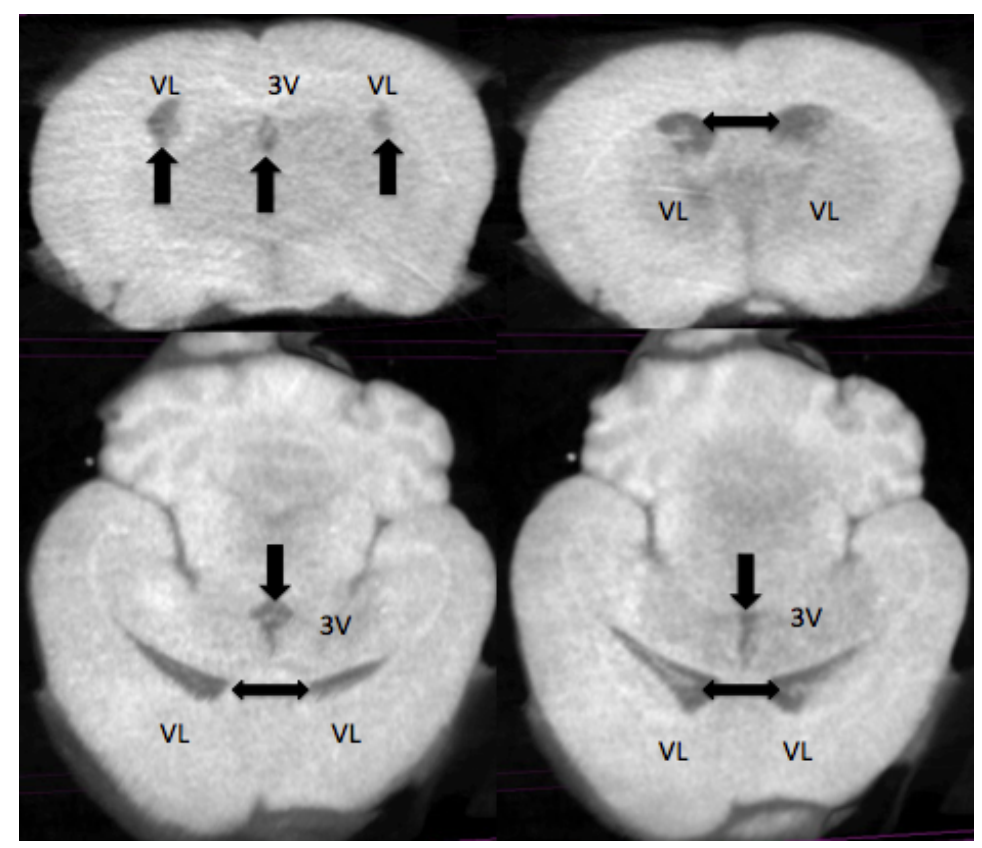

Figura 36. Fotomicrografia do cérebro de um dos camundongos Nude. Na imagem é possível identificar a presença de plexo coróide nas regiões dos ventrículos laterais (VL) e no terceiro ventrículo (3V). As setas apontam o local onde está o plexo coróide. 
Esses dados sugerem que camundongos Nude não tiveram alterações morfológicas no cérebro quando comparados ao de camundongos selvagens e heterozigotos para Foxn1. Todos os três grupos também apresentaram similaridades quando seus cérebros foram comparados anatomicamente, e com relação ao peso (Fig. 32) e medidas (Tab. 1)

Outra pergunta levantada neste trabalho foi sobre a possibilidade de FoxN1 ter algum papel na manutenção dos ventrículos cerebrais, uma vez que foi mostrado que se tem a expressão desse gene nos plexos coróides do cérebro de M. musculus. Pelas análises de microtomografia, foi possível identificar que não havia colabamento destas estruturas nos indivíduos Nude. Em todos animais (nos três grupos de camundongos estudados) os ventrículos mostravam-se "abertos" e os plexos coróides no seu interior estavam visíveis (Fig. 34 e 36). Tais dados sugerem que a ausência do gene não afetou necessariamente a formação dos ventrículos e/ou do plexo coróide

\subsection{Análise do paciente heterozigoto para FOXN1.}

Devido à colaboração com o Laboratório de Citogenética Clínica, da Faculdade de Saúde da UnB, foi identificado um paciente com uma deleção no gene FOXN1 em heterozigose, através da técnica de Microarranjo cromossômico (CMA) que apresentava fenótipo sindrômico descrito a seguir.

O paciente, hoje com aproximadamente um ano e oito meses de idade, foi encaminhado ao ambulatório de Genética do HUB-UnB, inicialmente com um diagnóstico de Sequência de Pierre-Robin. A criança foi atendida pela primeira vez no dia 17 de maio de 2013, momento em que foi feita sua anamnese. O paciente é filho de pais não-consanguíneos e apresenta malformações faciais como micrognatia e retrognatia, palato ogival e parcialmente fendido, língua posteriorizada, ocasionando dificuldade respiratória moderada; fenótipos sugestivos da sequência de Pierre-Robin (Moore et al., 2013; O'Rahilly e Muller, 1996). Notou-se também durante a análise clínica, o formato incomum da parte posterior da cabeça (Figura 37). No momento da consulta, a criança fazia uso de tubo nasofaríngeo e esse uso já acontecia desde o nascimento. O paciente nasceu de parto normal e teve cianose logo após o procedimento. Os profissionais da saúde liberaram suas vias aéreas e foi ofertado oxigênio com gradual melhora da cianose. 


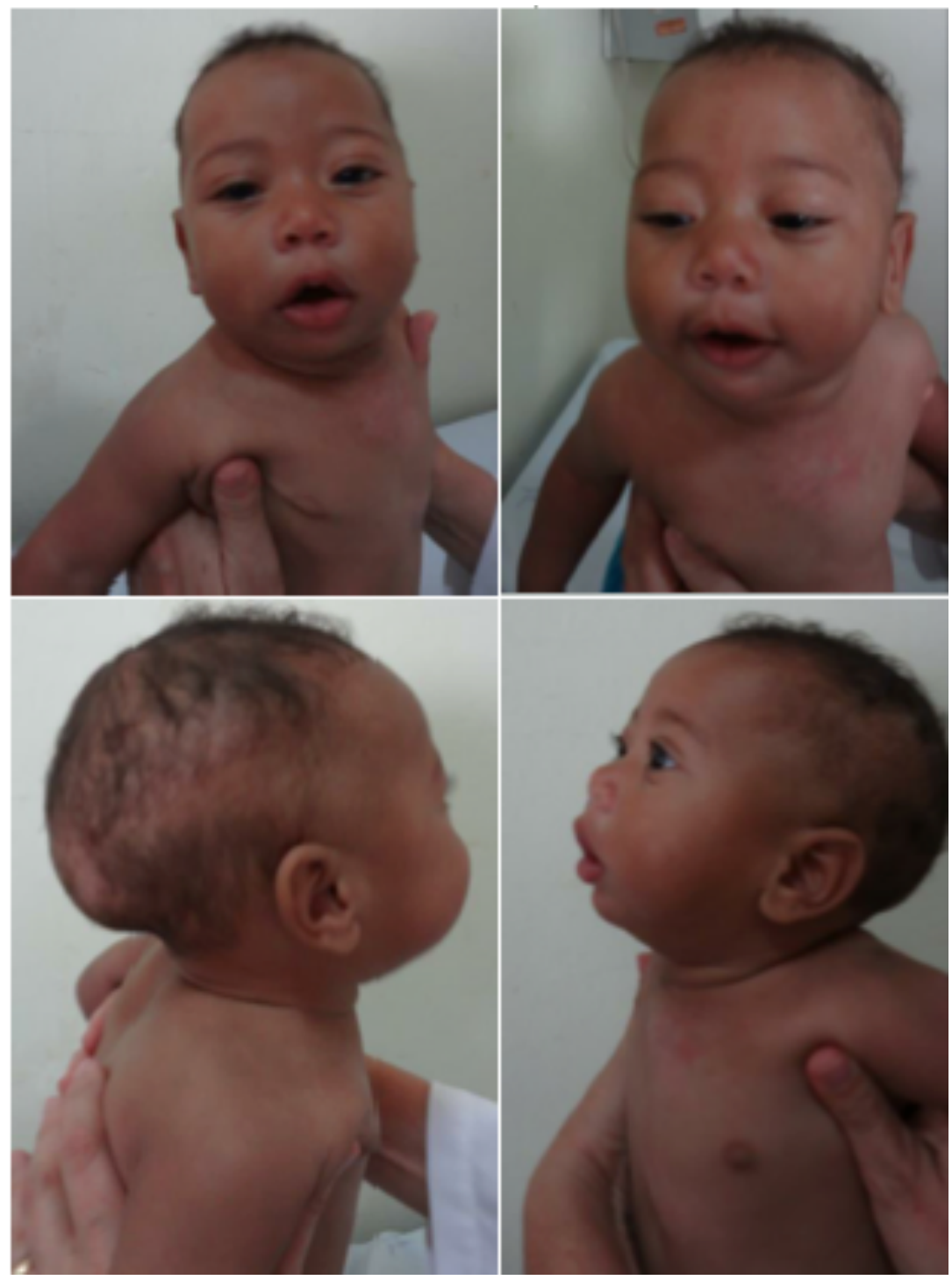

Figura 37. Fotografias tiradas do paciente com deleção parcial de FOXN1 em heterozigose. Nas imagens é possível visualizar algumas das características descritas em sua anamnese, como a micrognatia e retrognatia e o formato incomum de seu crânio na parte posterior da cabeça. As imagens foram autorizadas pela família através da assinatura do termo de consentimento livre e esclarecido.

Foi realizado um exame molecular de análise cromossômica por Chromosomal Microarray (CMA). O CMA é a técnica mais utilizada para a triagem de alterações cromossômicas submicroscópicas (Sagoo et al., 2009), seja por deleção ou duplicação. Essa técnica de citogenética molecular permite verificar se há perdas ou ganhos de segmentos cromossômicos submicroscópicos no genoma de um indivíduo, detectando alterações cromossômicas de 10 a 100 vezes menores do que é visível ao microscópio óptico, dependendo da plataforma utilizada. O CMA foi realizado também em amostras de sangue dos pais biológicos do paciente e o resultado foi normal, sendo a deleção de novo. 
O exame mostrou uma deleção no cromossomo 17, de aproximadamente 9.300 pares de base. O cromossomo 17 contém muitos genes e, entre eles, está presente o gene FOXN1 na região do braço longo (q) na posição q11.2 (Figura 38). A região deletada do paciente inclui uma extensa região intrônica mas também encobre os dois primeiros éxons do gene. (Figura 39 e 40$)$.

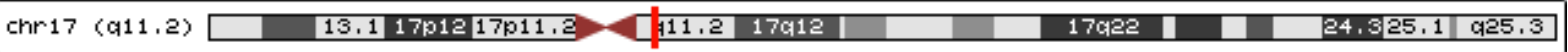

Figura 38. Imagem mostra uma representação do cromossomo 17 humano. O detalhe em vermelho mostra a região onde se localiza o gene FOXN1 na espécie, na região 17q11.2. A imagem foi retirada do sítio OMIM (http://genome.ucsc.edu/cgibin/hgTracks?db=hg19\&position= $=$ hr17\%3A2683324826865174\&hgsid=385805383 _rOkBAv6YadzQvRAkeaFJ6xFK1Y1A).

A partir dos dados apresentados, conclui-se que a região deletada no paciente em questão não inclui os éxons codificantes do domínio de ligação ao DNA, tampouco aos relacionados com a transcrição do domínio de ativação, localizado entre os sétimo e oitavo éxons, com similaridade entre espécies, mas inclui o éxon 2 que é o éxon de ancoragem para a expressão alternativa do éxon 1a ou 1b (Schorpp et al., 1997) e o códon iniciador. 


\begin{tabular}{|c|c|c|c|c|c|c|c|c|c|c|c|c|c|}
\hline \multirow{5}{*}{$\begin{array}{r}\text { DELECAO } \\
\text { F0XN1 } \\
\text { Consensus }\end{array}$} & 1768117690 & 17700 & 17710 & 17720 & 17730 & 17740 & 17750 & 17760 & 17770 & 17780 & 17790 & 17800 & 17810 \\
\hline & \multirow{3}{*}{\multicolumn{13}{|c|}{ 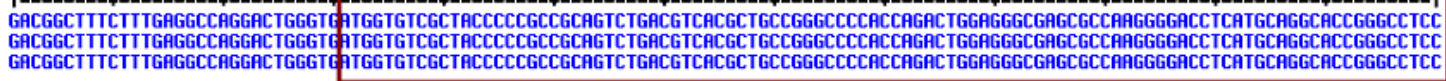 }} \\
\hline & & & & & & & & & & & & & \\
\hline & & & & & & & & & & & & & \\
\hline & 1781117820 & 17830 & 17840 & 17850 & 17860 & 17870 & 17880 & 17890 & 17900 & 17910 & 17920 & 17930 & 17940 \\
\hline DELECAO & \multirow{3}{*}{\multicolumn{2}{|c|}{$\begin{array}{l}\text { CAGGCTCCCCTGCCCCACAGGGT } \\
\text { CAGGCTCCCCTGCCCCACAGAGT } \\
\text { CAGGCTCCCCTGCCCCACAGAGT }\end{array}$}} & \multirow{3}{*}{\multicolumn{11}{|c|}{ 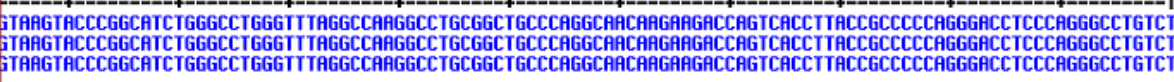 }} \\
\hline \multirow{3}{*}{ Consensus } & & & & & & & & & & & & & \\
\hline & & & & & & & & & & & & & \\
\hline & 1794117950 & 17960 & 17970 & 17980 & 17990 & 18000 & 18010 & 18020 & 18030 & 18040 & 18050 & 18060 & 18070 \\
\hline DELECARO & \multirow{3}{*}{\multicolumn{13}{|c|}{ 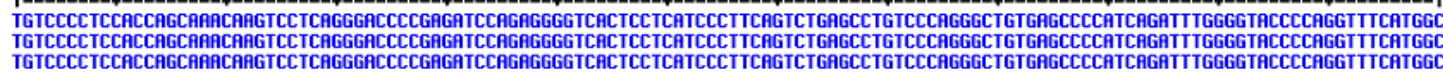 }} \\
\hline \multirow{3}{*}{$\begin{array}{r}\text { FOXN1 } \\
\text { Consensus }\end{array}$} & & & & & & & & & & & & & \\
\hline & & & & & & & & & & & & & \\
\hline & 1807118080 & 18090 & 18100 & 18110 & 18120 & 18130 & 18140 & 18150 & 18160 & 18170 & 18180 & 18190 & 18200 \\
\hline \multirow{4}{*}{$\begin{array}{r}\text { DELECA0 } \\
\text { F0XN1 } \\
\text { :onsensus }\end{array}$} & \multirow{3}{*}{\multicolumn{13}{|c|}{ 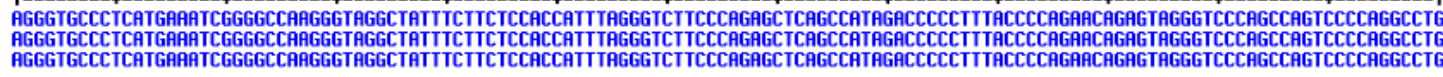 }} \\
\hline & & & & & & & & & & & & & \\
\hline & & & & & & & & & & & & & \\
\hline & 1820118210 & 18220 & 18230 & 18240 & 18250 & 18260 & 18270 & 18280 & 18290 & 18300 & 18310 & 18320 & 18330 \\
\hline \multirow{4}{*}{$\begin{array}{r}\text { DELECAO } \\
\text { F0XN1 } \\
\text { Consensus }\end{array}$} & \multirow{3}{*}{\multicolumn{13}{|c|}{ 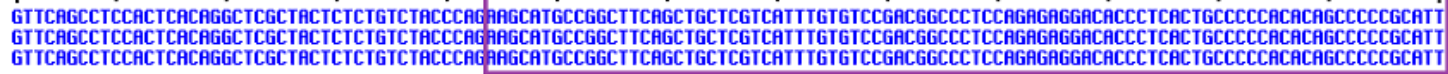 }} \\
\hline & & & & & & & & & & & & & \\
\hline & & & & & & & & & & & & & \\
\hline & 833118340 & 18350 & 18360 & 18370 & 18380 & 18390 & 18400 & 18410 & 18420 & 18430 & 18440 & 18450 & 1846 \\
\hline \multirow{3}{*}{$\begin{array}{r}\text { DELECAO } \\
\text { FOXN1 } \\
\text { Consensus }\end{array}$} & \multirow{2}{*}{\multicolumn{13}{|c|}{$\begin{array}{l}\text { GCGTCACCAGGGCCCGAGCARGTCCAGGGCCACTGCCCAGCCGGCCCCGGCCCTGGGCCCTTCAGGCTCTCACCCTCAGACARGTATCCTGGCTTTGGCTTTGAGGAGGCC } \\
\text { GCGTCACCAGGGCCCGAGCARGTCCAGGGCCACTGCCCAGCCGGCCCCGGCCCTGGGCCCTTCAGGCTCTCACCCTCAGACARGTATCCTGGCTTTGGCTITGAGGAGGCC } \\
\text { GCGTCACCAGGGCCCGAGCAAGTCCAGGGCCACTGCCCAGCCGGCCCGGCCCTGGGCCCTTCAGGCTCTCACCCTCAGACARGTATCCTGGCTITGGCTITGAGGAGGCC }\end{array}$}} \\
\hline & & & & & & & & & & & & & \\
\hline & 1846118470 & 18480 & 18490 & 18500 & 18510 & 18520 & 18530 & 18540 & 18550 & 18560 & 18570 & 185 & 18590 \\
\hline \multirow{4}{*}{$\begin{array}{r}\text { DELECA0 } \\
\text { F0XN1 } \\
\text { Consensus }\end{array}$} & \multirow{3}{*}{\multicolumn{13}{|c|}{ 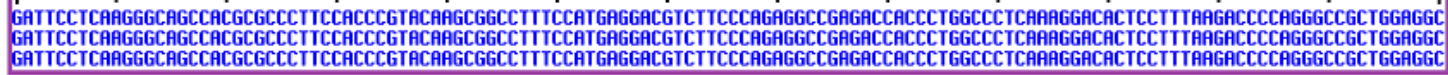 }} \\
\hline & & & & & & & & & & & & & \\
\hline & & & & & & & & & & & & & \\
\hline & 18591 & 18610 & 18620 & 18630 & 18640 & 18650 & 18660 & 18670 & 18680 & 18690 & 18700 & & 18720 \\
\hline $\begin{array}{r}\text { DELECAO } \\
\text { FOXN1 } \\
\text { Consensus }\end{array}$ & \multicolumn{13}{|c|}{ 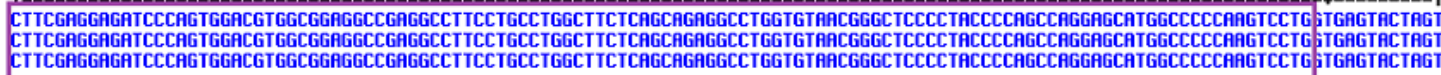 } \\
\hline
\end{tabular}

Figura 39. Alinhamento de parte da sequência deletada no cromossomo 17 do paciente heterozigoto para FOXN1 com a sequência do gene em questão. A região deletada inclui os dois primeiros éxons do gene, como mostrado na figura em vermelho escuro, a localização do primeiro éxon e em roxo a localização do segundo éxon. A deleção tem 9332 pb de extensão e na figura só foi mostrada a parte que inclui a parte codificante, todo o resto está em regiões intrônicas antes do primeiro éxon e depois do segundo. O alinhamento foi feito com o auxílio do software Multalin (http://multalin.toulouse.inra.fr/).
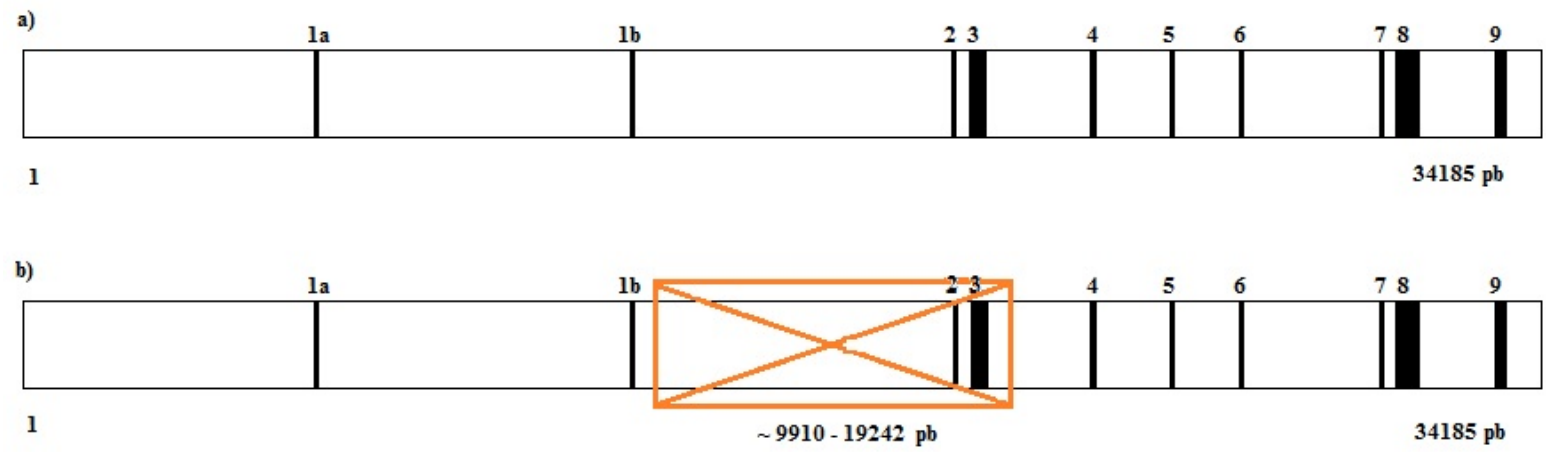

Figura 40. Representação da estrutura do gene FOXN1 na espécie humana. O gene apresenta oito éxons e tem aproximadamente 31898 pares de base de extensão. Em a) a estrutura do gene em questão mostrando suas regiões promotora e finalizadora em lilás (próximos às extremidades da figura). Em b) uma representação do ponto de deleção do paciente heterozigoto para FOXN1 (retângulo marcado com “x”). Esse ponto é aproximado a $9910^{a}$ base até a $19242^{a}$ base aproximadamente. Essa região encobre, além de uma extensa região intrônica, os dois primeiros éxons do gene. Essa aproximação foi feita após análise do alinhamento pelo software Multalin, (http://multalin.toulouse.inra.fr/) da sequência de FOXN1 com a sequência perdida pelo cromossomo do paciente. 


\section{DISCUSSÃO}

A análise in silico da proteína de FoxN1 de G. gallus mostrou que ela apresenta, além de tamanho similar, as mesmas regiões conservadas já vistas em outras espécies, sendo elas o domínio de ligação ao DNA e o domínio de ativação, em menor escala, como visto nos alinhamentos da proteína FoxN1 entre espécies e de todas as proteínas Fox de G. gallus (Fig. 21). O gene FoxN1 de G. gallus também apresentou semelhança de forma em relação a outras espécies, apresentando oito éxons, porém sem a identificação até o momento de éxons alternativos de ligação tecido-específica como vistos em humanos e em camundongos (Fig. 18) (Schorpp et al., 1997).

O domínio $f k h$ é codificado pelos quarto, quinto e sexto éxons da sequência do gene, e o domínio de ativação é codificado pelos sétimo e oitavo éxons (Fig. 18). Dentre as sequências de aminoácidos correspondentes às proteínas da subclasse FoxN em G. gallus, FoxN1 e FoxN4, apresentaram maior similaridade que FoxN2 e FoxN3 (Figs. 24 e 25), sugerindo uma divergência na evolução fillogenética dessa subclasse. De acordo com Mazet e colaboradores (2003), existem resíduos de aminoácidos nas sequências de FoxN que são candidatos a terem papeis funcionais importantes na divergência seletiva dessa subclasse e podem representar os resíduos responsáveis pela atividade específica e pela divergência da ligação dessas proteínas ao DNA.

FoxN1 e FoxN4 estão ambos envolvidos na diferenciação celular durante o desenvolvimento embrionário (Hannenhaalli e Kaestner, 2009). FoxN1 age na diferenciação dos folículos capilares e nas células epiteliais do timo e FoxN4 está envolvido na diferenciação das células amácrinas e horizontais durante a formação da retina em camundongos (Li et al., 2004). Também está envolvido na especificação dos interneurônios na região ventral da espinha dorsal e é essencial para a formação do canal átrio-ventricular no desenvolvimento do coração em D. rerio (zebrafish) (Chi et al., 2008), o que pode instigar ainda mais a possibilidade de que seu homólogo, FoxN1 tenha um papel na formação do SNC.

A análise por qPCR dos estágios embrionários selecionados de G. gallus mostrou a amplificação de FoxN1 nos embriões de G. gallus desde o estágio primordial de 18 h (HH 4) que consiste no estágio de início da neurulação, em que a placa neural começa a se formar, e ainda não há formação de queratinócitos ou epitélio tímico que possam justificar essa expressão, sendo então mais um indicativo de que FoxN1 pode estar sendo expresso no SNC (Figs. 26 e 27). 
Darnell e colaboradores (2014) estudaram a expressão temporal e espacial de FoxN1 em embriões de G. gallus por meio de hibridização in situ. Este grupo teve como foco apenas a expressão deste gene nos primórdios do timo, pele e penas. Os resultados encontrados corroboram parcialmente os aqui descritos. Este grupo não detectou expressão gênica de FoxN1 antes do estágio de $24 \mathrm{~h}$ (HH 6), sendo bem expresso no timo a partir do estágio de 33 h (HH 10) de desenvolvimento e, na pele partir do estágio de $48 \mathrm{~h}$ (HH 12) de desenvolvimento.

Como Darnell e colaboradores (2014), foi detectada uma expressão crescente a partir do estágio de 24 horas de desenvolvimento. Neste período o embrião forma ativamente os primórdios do SNC, há diferenciação de células do ectoderma de superfície estimuladas pela notocorda. As células do ectoderma de superfície que respondem ao estimulo da notocorda, formam a placa neural, que é constituída por células que darão origem ao tubo neural, e células da crista neural, que vão se posicionar bilateralmente a este tubo. Estas células tem a habilidade migratória, e dependendo de onde estão no tubo neural, participarão na formação de estruturas distintas. Entre outras estruturas, as células da crista neural que se localizam bilateralmente, ao primórdio da terceira vesícula encefálica, o rombencéfalo, participarão na formação dos arcos faríngeos (Fig. 31) (Moore et al., 2013).

O timo se forma no terceiro arco faríngeo, e sua endoderme se separa da faringe por volta do quinto dia de incubação no embrião de galinha (Le Douarin e Jotereau, 1975). Sendo assim, nossos resultados estão alinhados com aqueles descritos por Darnell e colaboradores (2014) no que diz respeito a expressão no primórdio do timo. Porém, espera-se que esta diferenciação celular das células da crista neural seja paulatina e que a expressão de genes envolvidos no desenvolvimento de estruturas específicas comece em estágios precedentes e perdure até a formação completa da estrutura, e muitas vezes participando da função da estrutura no adulto, como é o caso de FoxN1 no timo e na pele.

Estudos de expressão em órgãos de indivíduos jovens mostraram uma expressão importante deste gene no timo (Fig. 28) corroborando vários estudos (Albuquerque et al., 2002; Bleul et al., 2006; Cheng et al., 2009; Dooley et al., 2005), inclusive Darnell et al., 2014. Não foi detectado em nosso estudo expressão no cérebro do jovem adulto nem pela análise molecular de qPCR em G. gallus nem por análise macroscópica dos cérebros de $M$. musculus (Fig. 33), apesar de Amorosi e colaboradores (2008), por meio de hibridização in situ em cortes histológicos de cérebro de camundongo, terem visualizado expressão deste gene no plexo coróide. 
Também não foi detectada nenhum tipo de má formação do plexo ou dos ventrículos cerebrais. Quando comparamos macroscopicamente os cérebros dos três grupos analisados, vimos porém que o cérebro de um indivíduo nude aparenta estar mais liso na região cortical, possuindo menos giros e sulcos (Fig. 36). Esses achados podem indicar que Foxn1 pode estar envolvido na secreção do líquido cefalorraquidiano, pois este contém as moléculas principais para a formação e manutenção do SNC. É possível que FoxN1 tenha um papel menos estruturalmente impactante, como sugerido em 2010, por Amorosi e colaboradores, como por exemplo, possa exercer uma função de co-fator, mais do que de controlador gênico, isso explicaria pelo menos parcialmente o grande spectrum de fenótipos nos pacientes descritos pelo grupo (Amorosi et al., 2008 e 2010). Outros órgãos abdominais analisados não mostraram qualquer diferença anatômica quando Foxn1 estava presente ou mutado.

Os dados preliminares de imunofluorescência corroboram também com a expressão de FoxN1 na região dos arcos faríngeos (Fig. 30), onde o primórdio do timo é formado em estágios subsequentes. Estes resultados corroboram os descritos por Darnell e colaboradores (2014).

O paciente analisado neste estudo apresentava uma deleção parcial no gene FOXN1 em heterozigose e característica sindrômicas correspondentes da Sequência de Pierre-Robin, como a micrognatia e retrognatia, língua posteriorizada e palato ogival parcialmente fendido (Fig. 37). Essa constatação é interessante pois a Sequência de Pierre-Robin é oriunda de defeitos de formação dos arcos faríngeos, local onde FOXN1 é expresso. Esses dados corroboram a ideia de que a deleção de FOXN1 no paciente seja responsável pelo fenótipo encontrado.

Notou-se também durante a análise clínica, o formato incomum da parte posterior da cabeça do paciente (Fig. 37). Essa característica pode ser consequência de eventos comprometidos durante o desenvolvimento do SNC e mais estudos de imagens, como tomografias devem ser feitas para investigar melhor a extensão dessa má formação.

A região deletada do paciente inclui uma extensa região intrônica mas também encobre os segundo e terceiro éxons do gene (Figura 39 e 40). A partir dos dados apresentados, pode-se perceber que a região deletada no paciente em questão não inclui os éxons codificantes do domínio de ligação ao DNA, tampouco aos relacionados com a transcrição do domínio de ativação, localizado entre os sétimo e oitavo éxons, com similaridade entre espécies, mas inclui o segundo éxons que é o de ancoragem para a expressão alternativa do éxon 1a ou 1b (Schorpp et al., 1997) e é o que possui o códon iniciador. Entretanto, ao longo do íntron subsequente à deleção e do éxon seguinte é possível 
encontrar vários possíveis códons iniciadores (ATG) que manteriam a fase de leitura, para a construção de uma proteína FOXN1 incompleta contendo os domínios de ligação ao DNA e de ativação. Não se sabe porém se foram perdidos na deleção elementos reguladores importantes, inclusive sítios de splicing.

Em conjunto estes dados sugerem que estes fenótipos podem ser consequência ou de uma haploinsuficiência gênica, ou ainda a possibilidade que a proteína mutada ocupe o local de ativação/repressão, sem efetuar sua função e prejudicando o posicionamento de outros fatores de transcrição.

Os estudos em G. gallus auxiliam na compreensão da expressão temporal e espacial de FoxN1 estudado em outros organismos modelo, como o camundongo. A expressão do gene em estágios do início da formação do SNC em G. gallus estão em sintonia com os achados que mostram que há expressão de Foxn1 em estruturas cerebrais (plexo coroide) em $M$. musculus e a visualização de que o cérebro de um camundongo nude apresenta menos giros e sulcos também corrobora essa sintonia.

Como FoxN1 também é um fator de transcrição conservado e homólogo em humanos, as características mostradas no paciente estudado ajudam a aumentar a hipótese de que FOXN1 possa ter algum papel no desenvolvimento do SNC, uma vez que já há uma hipótese de que seu fenótipo pode estar associado à Sequência de Pierre-Robin e esta é uma síndrome originada de uma estrutura onde há expressão de $F O X N 1$, e que a forma peculiar da parte posterior de sua cabeça é sugestiva de um defeito na correta formação do SNC. 


\section{CONCLUSÕES}

A proteína FoxN1 tem grande similaridade evolutiva, tanto em sequência de nucleotídeos quanto em sequência de aminoácidos, sugerindo um papel funcional importante e provavelmente conservado. Comparação com genoma de outros modelos mostrou que a proteína contem domínios de ligação ao DNA e de ativação conservados. A proteína não contem domínios transmembranares, o que corrobora com sua função de fator de transcrição.

$>$ Em G. gallus, o nível de similaridade entre FoxN1 e FoxN4 sugere que estas proteínas surgiram de uma duplicação antiga e que são homólogas.

$>$ Em embriões de G. gallus em estágios iniciais, verificou-se expressão crescente de FoxN1 nos primeiros estágios do desenvolvimento, coincidente com a formação de estruturas primordiais do SNC e da face. Dados preliminares de imunofluorescência, sugerem, pelo menos em estágio pós-dobramento, a presença desta proteína nos arcos faríngeos.

Cérebros de camundongos selvagem $($ Foxn1 +/+), heterozigotos (Nude/+) e Nudes (Foxn1 -/-), mostraram-se estruturalmente similares, sem comprometimento tanto do plexo coróide quanto dos ventrículos. Esta observação corrobora a hipótese de Amorosi et al. (2010) de que FoxN1 possa exercer uma função de co-fator, mais do que de controlador gênico.

$>$ Em adição, identificou-se um paciente com malformação cefálica e portador de uma deleção dos primeiros éxons de FOXN1 em heterozigose. Estes achados fortalecem a hipótese de uma função de FoxN1 no desenvolvimento do SNC e corroboram estudos funcionais que mostram a participação desta proteína na formação dos arcos faríngeos. Estudos moleculares complementares são necessários para mapear exatamente a deleção no paciente, assim como exames de imagens mais acurados da cabeça do paciente devem ser feitos para analisar a extensão da malformação do SNC. 


\section{REFERÊNCIAS BIBLIOGRÁFICAS}

Accili, D., Arden, K. C. 2004. FoxOs at the Crossroads of Cellular Metabolism, Differentiation and Transformation. Cell, 117(4): 421-426.

Albuquerque, A. S., Marques, J. G., Silva, S. L., Ligeiro, D., Devlin, B. H., Dutrieux, J., Cheynier, R., Pignata, C., Victorino, R. M. M., Markert, M. L., Sousa, A. E. 2002. Human FOXN1-Deficiency is Associated with aB Double-Negative and FoxP3+ T-Cell Expansions That Are Distincly Modulated upon Thymic Transplantation. Plos One 7(5): e37042.

Amorosi, S., D’Armiento, M., Calcagno, G., Russo, I., Adriani, zM., Christiano, A. M., Weiner, L., Brissette, J. L., Pignata, C. 2008. FOXN1 homozygous mutation associated with anencephaly and severe neural tube defect in human athymic Nude/SCID fetus. Clin Genet 73: $380-384$.

Amorosi, S., Vigliano, I., Del Giudice, E., Panico, L., Maruotti, G. M., Fusco, A., Quarantelli, M., Ciccone, C., Ursini, M. V., Martinelli, P., Pignata, C. 2010. Brain alteration in a Nude/SCID fetus carrying FOXN1 homozygous mutation. Journal of the Neurological Sciences 298: 121-123.

Anderson, G., Jenkinson, E. J. 2001. Lymphostromal interations in thymic development and function. Nat Rev Immunol 1(1): $31-40$.

Baroneza, J. E. Identificação e análise da expressão de genes codificando membros da família NEPH/ROUGHEST em G. gallus. (Dissertação). Ribeirão Preto: Revista Medicina. 2009.

Baroneza, J. E., Taylor A. P., Araujo, C., Fascineli, M. L. Atividades práticas em embriologia. 1 ed. Brasília, DF: Editora da Universidade de Brasília. 2011. 120 p.

Baxter, R. M., Brissette, J. L. 2002. Role of the Nude Gene in Epithelial Terminal Differentiation. J Invest Dermaltol 118: 303 - 309.

Bleul, C. C., Corbeaux, T., Reuter, A., Fisch, P., Monting, J. S., Boehm, T. 2006. Formation of a functional thymus initiated by a postnatal epithelial progenitor cell. Nature letters 441 : $992-996$.

Brasil, Lei $\mathrm{n}^{\mathrm{o}} 11.794$, de 08 de Outubro de 2008. Regulamenta o inciso VII do $\S$ 1o do art. 
225 da Constituição Federal, estabelecendo procedimentos para o uso científico de animais; revoga a Lei no 6.638, de 8 de maio de 1979; e dá outras providências. Diário Oficial da República Federativa do Brasil. Brasília, DF. D.O.U. de 09/10/2008, P. 1.

Bulmer, R., Pic-Taylor, A., Whitehall, S. K., Martin, K. A., Millar, J. B., Quinn, J., Morgan, B. A. 2004. The forkhead transcription factor Fkh2 regulates the cell division cycle of Schizosaccharomyces pombe. Eukaryotic cell. 3(4): 944-954.

Cai, J., Lee, J., Kopan, R., Ma, L. 2009. Genetic interplays between Msx2 and Foxn1 are required for Notch1 expression and hair shaft differentiation. Dev Biol. 15(326): 420 - 430.

Cai, J., Ma, L. 2011. Msx2 and Foxn1 Regulate Nail Homeostasis. Genesis 49: 449 - 459.

Carlsson, P., Mahlapuu, M. 2002. Forkhead Transcription Factors: Key Players in Development and Metabolism. Dev Biol 250: 1 - 23.

Cheng, L., Guo, J., Sun, L., Fu, J., Barnes, P. F., Metzger, D., Chambon, P., Oshima, R. G. Amagai, T., Su, D. M. 2009. Postnatal Tissue-especific Disruption of Transcription Factor FoxN1 Triggers Acute Thymic Atrophy. The Journal of Biological Chemistry 285(8): 5836 5847.

Chi, N. C., Shaw, R. M., De Val, S., et al. 2008. Foxn4 directly regulates tbx2b expression and atrioventricular canal formation. Genes Dev. 22:734-739.

Clark, K. L., Halay, E. D., Lai, E., Burley, S. K. 1993. Co-crystal structure of HNF-3/fork head DNA-recognition motif resembles histone H5. Nature 364: 412-420.

Clevidence, D. E., Overdier, D. G., Tao, W., Qian, X., Pani, L., Lai, E., Costa, R. H. 1993. Identification of the nine tissue specific transcription factors of the hepatocyte nuclear factor 3/forkhead DNA-binding domain family. National Academy of Science of the United States of America 90: 3948-3952.

Coffer, P. J., Burgering B. M. T. 2004. Forkhead-box transcription factors and their role in the immune system. Nature immunology 4: 889 - 899.

Darnell, D. K., Zhang, L. S., Hannenhalli, S., Yaklichkin, S. Y. 2014. Developmental expression of chicken FOXN1 and putative target genes during feather development. Int. J. Dev. Biol. 58: 57-64. 
Desmond, M. E., Jacobson, A. G. 1977. Embryonic brain enlargement requires cerebrospinal fluid pressure. Dev. Biol. 57: 188-198.

Dias, P. F. Estudo da ação de fatores físicos e químicos sobre a morfogênese de embriões de Gallus gallus domesticus, com ênfase no desenvolvimento do sistema nervoso central (Dissertação). Florianópolis, SC. 1996.

Dooley, J., Erickson, M., Roelink, H., Farr, A. G. 2005. Nude Thymic Rudiment Lacking Functional foxn1 Resembles Respiratory Epithelium. Developmental Dynamics 233: 1605 1612.

Duboule, D. 1994. Temporal Colinearity and the Phylotypic Progression; a Basis for the Stability of a Vertebrate Bauplan and the Evolution of Morphologies through Heterochrony. Development. Suppl. 135- 142.

Dziegielewska, K. M., Ek, J., Habgood, M. D., Saunders, N. R. 2001. Development of the choroid plexus. Microsc. Res. Tech. 52: 5-20.

Eyal-Giladi, H. 1991. The Early Embryonic Development of the Chick, as an Epigenetic Process. Critical Review of Poultrv Biology 3: 143 - 166.

Eyal-Giladi, H., Debby, H., Harel, N. 1992. The posterior section of the chick area pellucida and its involvement in hipoblast and primitive streak formation. Development. 116: 819 - 830.

Farley T. L. 2006. A reproductive history of mothers with spina bifida offspring a new look at old issues. Crebrospinal Fluid Research - 3, 10.

Festing, M. W., Lovell, D., Sparrow, S., May, D., Connors, T. A. 1978. An athymic nude mutation in the rat. Nature 274: $365-366$.

GeneCard: http://www.genecards.org/cgi-bin/carddisp.pl?gene=FOXN1 (acesso em 10/10/13)

Gilbert, S. F. Biologia do desenvolvimento. 3 ed. Ribeirão Preto, SP: Editora FUNPEC. 2003. $563 p$.

Gordon, J., Bennett, A. R., Blackburn, C. C., Manley, N. R. Gcm2 and Foxn1 mark early parathyroid- and thymus-specific domains in the developing third pharyngeal pouch. Mech. of 
Dev. 103(1-2): $141-143$.

Griffiths, A. J. F., Wessler, S. R., Lewontin, R. C., Caroll, S. B. Introdução à Genética. 9 ed. Rio de Janeiro, RJ: Editora Guanabara Koogan. 2009. 712 p.

Groenen, M. A. M., Crooijmans, R. P. M. A., Dijkhof, R. J. M., Acar, R., Van der Poel, J. J. 1999. Extending the chicken-human comparative map by placing 15 genes on the chicken linkage map. Anim. Genet. 30: 418-422.

Groenen, M. A. M., Cheng, H. H., Bumstead, N. 2000. A consensus linkage map of the chicken genome. Genome Research 10: 137-47.

Guthrie, S. 2007. Patterning and axon guidance of cranial motor neurons. Nature Reviews 8: $859-871$.

Hacker, U., Kaufmann, E., Hartmann, C., Jurgens, G., Knochel W., Jaeckle, H. 1995. The Drosophila fork head domain protein crocodile is required for the establishment of head structures. EMBO J. 14(21): 5306 - 5317.

Haesler, S., Wada, K., Nshdejan, A., Morrisey, E. E., Lints, T., Jarvis, E. D., Scharff, C. 2004. FoxP2 Expression in Avian Vocal Learners and Non-Learners. The Journal of Neuroscience 24(13): $3164-3175$.

Hamburger, V., Hamilton, H. L. 1992. A series of normal stages in the development of the chick embryo. Developmental dynamics 195: 231 - 272.

Hannenhalli, S., Kaestner, K. H. 2009. The evolution of Fox genes and their role in development and disease. Genetics 10: 233 - 240.

Hébert, J. M., McConnell, S. K. 2000. Targeting of CREto the Foxg1 (BF-1) locus mediates loxP recombination in the telencephalon and other developing head structures. Dev Biol. 15 222(2): 296-306.

Hoodless, P. A., Pye, M., Chazaud, C., Labbe, E., Attisano, L., Rossant, J., Wrana, J. L. 2001. FoxH1 (Fast) functions to specify the anterior primitive streak in the mouse. Genes Dev 15: $1257-1271$.

Hughes, A. L., M. K. Hughes. 1995. Small genomes for better flyers. Nature 377(6548): 391. 
Jackson, B. C., Carpenter, C., Nebert, D. W., Vasiliou, V. 2010. Update of human and mouse forkhead box (FOX) gene families. Human Genomics 4(5): 345 - 352.

Jones, C. T., Morrice, D. R., Paton, I. R., Burt, D. W. 1997. Gene homologs on human chromosome $15 \mathrm{q} 21-\mathrm{q} 26$ and a chicken microchromosome identify a new conserved segment. Mamm. Genome 8: 436-440.

Jonsson, H., Peng, S. L. 2005. Forkhead transcription factores in immunology. Cell. Mol. Life. Sci. 62: $397-409$.

Kaestner, K. H., Knochel, W., Martínez, D. E. 2000. Unified nomenclature for the winged helix/forkhead transcription factors. Genes Dev 14: 142 - 146.

Katoh, M. Katoh, M. 2004. Human FOX gene family. Int. J. Oncol. 25(5): 1495-1500.

Kaufmann, E., Knochel, W. 1996. Five years on the wings of fork head. Mechanisms of Development 57: 3 - 20 .

Kim, H. Y., Kim, Y. K., Song, I. H., Baek, S. H., Lee, S. R., Kim, J. H., Kim, J. R. 2005. Down-Regulation of a Forkhead Transcription Factor, FOXO3a, Accelerates Cellular Senescence in Human Dermal Fibroblasts. Journal of Gerontology: BIOLOGICAL SCIENCES 60A(1): 4-9.

Labosky, P. A., Winnier, G. E., Jetton, T. L., Hargett, L., Ryan, A. K., Rosenfeld, M. G., Parlow, A. F., Hogan, B. L. 1997. The winged helix gene, Mf3, is required for normal development of the diencephalon and midbrain, postnatal growth and the milk-ejection reflex. Development 124: 1263-1274.

Lai, E., Prezioso, V. R., Smith, E., Litvin, O., Costa, R. H., Darnell, J. E. Jr. 1990. HNF-3A, a hepatocyte-enriched transcription factor of novel structure is regulated transcriptionally. Genes Dev 4: 1427-1436.

Lai, E., Clark, K. L., Burley, S. K., Darnell, J. E. Jr. 1993. Hepatocyte nuclear factor 3/fork head or 'winged helix' proteins: a family of transcription factors of diverse biologic function. Proc Natl Acad Sci USA, 90: 10421-10423.

Lai, C. S., Fisher, S. E., Hurst, J. A., Vargha-Khadem, F., Monaco, A. P. 2001. A forkhead- 
domain gene is mutated in a severe speech and language disorder. Nature 413(6855): 519-23.

Le Douarin, N. M., Jotereau, F. V. 1975. Tracing of cells of the avian thymus through embryonic life in interspecific chimeras. The Journal of Experimental Medicine 142: 17 - 40.

Lee, D., Prowse, D. M., Brissette, J. L. 1999. Association between Mouse nude Gene Expression and the Initiation of Epithelial Terminal Differentiation. Dev Biol. 208: 362 -374.

Lehmann, O. J., Sowden, J. C., Carlsson, P., Jordan, T., Bahttacharya, S. S. 2003. Fox's in development and disease. TRENDS in Genetics 19(6): 339-344.

Li, S., Mo, Z., Yang, X., Price, S. M., Shen, M. M., Xiang, M. 2004. Foxn4 controls the genesis of amacrine and horizontal cells by retinal progenitors. Neuron . 43:795-807.

Macchia, P. E., Felice, M. D., Lauro, R. D. 1999. Molecular genetics of congenital hypothyroidism. Curr. Opin. Genet. Dev. 9: 289-294.

Marsden, I., Jin, C., Liao, X. 1998. Structural changes in the region directly adjacent to the DNA-binding helix highlight a possible mechanism to explain the observed changes in the sequence-specific binding of winged helix proteins. J. Mol. Biol. 278: 293-299.

Mazet, F., Yu, Jr. K., Liberles, D. A., Holland, L. Z., Shimeld, S. M. 2003. Phylogenetic relationships of the Fox (Forkhead) gene family in the Bilateria. Gene. 316: 79-89.

Mecklenburg, L., Nakamura, M., Sundberg, J. P., Paus, R. 2001. The nu mouse skin phenotype: the role of foxn1 in hair follicle development and cycling. Exp Mol Pathol 71: 171 -178 .

Miyan, J. 2009. CSF circulation and cerebral cortex development. Cerebrospinal fluid research 6(2): S13.

Moore, K. L., Persaud, T. V. N., Torchia, M. G. Embriologia clínica. 9 ed. Rio de Janeiro, RJ: Editora Elsevier. 2013. 540 p.

Morrison, J., Partridge, T., Bou-Gharios, G. 2004. Nude mutation influences limb skeletal muscle development. Matrix Biology 23: 535 - 542. 
Nakamura, Y., Ichinohe, M., Hirata, M., Matsuura, H., Fujiwara, T., Igarashi, T., Nakahara, M., Yamaguchi, H., Yasugi, S., Takenawa, T., Fukami, K. 2008. Phospholipase C-d1 is an essential molecule downstream of Foxn1, the gene responsible for the nude mutation, in normal hair development. FASEB J. 22: 841- 849.

Nanda, I., Z. Shan, M., Schartl, D. W., Burt, M., Koehler, H. G., Nothwang, F., Grutzner, I. R., Paton, D., Windsor, I., Dunn et al. 1999. 300 million years of conserved synteny between chicken Z and human chromosome 9. Nat. Genet. 21: 258-259.

Nehls, M., Pfeifer, D., Schorpp, M., Hedrich, H., Boehm, T. 1994. New member of the winged-helix protein family disrupted in mouse and rat nude mutations. Nature 372: $103-$ 107.

Nelms, B. L., Labosky, P. A. 2010. Transcriptional Control of Neural Crest DevelopmentMorgan \& Claypool Life Science. San Rafael, CA.

Ogasawara, M., Satou, Y. 2003. Expression of FoxE and FoxQ genes in the endostyle of Ciona intestinalis. Dev. Genes. Evol. 213: 416-419.

O’Harilly, R, e Müller, F. Embriologia e Teratologia humanas. 3 ed. Rio de Janeiro, RJ: Editora Guanabara Koogan. 2005. 482 p.

Pic, A., Lim, F. L., Ross, S. J., Veal, E. A., Johnson, A. L., Sultan, M. R. A., West, A. G., Johnston, L. H., Andrew D., Sharrocks, A. D., Morgan, B. A. 2000. The forkhead protein Fkh2 is a component of the yeast cell cycle transcription factor SFF. The EMBO Journal - 19: $3750-3761$.

Pierrou, S., Hellqvist, M., Samuelsson, L., Enerback, S., Carlsson, P. 1994. Cloning and characterization of seven human forkhead proteins: binding site specificity and DNA bending. EMBO J. 13: 5002-5012.

Prowse, D. M., Lee, D., Weiner, L., Jiang, N., Magro, C. M., Baden, H. P., Brissette, J. L. 1999. Ectopic Expression of the nude Gene Induces Hyperproliferation and Defects in Differentiation: Implications for the Self-Renewal of Cutaneous Epithelia. Develop Biol 212: $54-67$. 
Redzic, Z. B., Preston, J. E., Duncan, J. A., Chodobski, A., Szmydynger-Chodobska, J. 2005. The Choroid Plexus-Cerebrospinal Fluid System: From Development to Aging. Curr Topics in Develop Biol 71: 1 - 52.

Romanes, G. J. Darwin and After Darwin. 3 ed. Chicago, USA: Editora The Open Court Publishing Company. 1901. v 1.

Romano, R., Palamaro, L., Fusco, A., Iannace, L., Maio, S., Vigliano, I., Giardino, G., Pignata, C. 2012. From Murine to Human NUDE/Scid: The Thymus, T-Cell Development and the Missing Link. Clinical and Development Immunology 2012: 1 - 12.

Romano, R., Palamaro, L., Fusco, A., Giardino, G., Gallo, V., Del Vecchio, L., Pignata, C. 2013. FOXN1: a master regulator gene of thymic epithelial development program. Frontiers in immunology 4(187): $1-13$.

Sagoo G. S., Butterworth, A. S., Sanderson, S., Shaw-Smith, C., Higgins, J. P., Burton, H. 2009. Array CGH in patients with learning disability (mental retardation) and congenital anomalies: updated systematic review and meta-analysis of 19 studies and 13,926 subjects. Genetics in Medicine 11(3): 139 - 146.

Schlake, T., Schorpp, M., Maul-Pavicic, A., Malashenko, A. M., Boehm, T. 2000. Dev Dynamics 217: 368 - 376 .

Schorpp, M., Hofmann, M., Dear, T. N., Boehm, T. 1997. Characterization of mouse and human nude genes. Immunogenetics 46: 509 - 515.

Schowolfen, G. C, Bleyl, S. B., Brauer, P. R., Francis-West, P. H. Larsen's Human Embryology. 4 ed. Nova Iorque, Edinburgh, USA: Editora Churchill Livigstone. 2009. 712 p.

Schuddekopf, K., Schorpp, M., Boehm, T. 1996. The whn transcription factor encoded by he nude locus contains an evolutionary conserved and functionally indispensable activation domain. Proc. Natl. Acad. Sci. USA. 93: 9661-9664.

Shostak, S. Embryology: an Introduction to Developmental Biology. 1 ed. Nova Iorque, USA: Editora Harpercollins College Div. 1991. 778p. 
Tiersch, T. R., Wachtel, S. S. 1991. On the Evolution of Genome Size in Birds. J. Hered. 82: $363-368$.

Van Dongen, M.J., Cederberg, A., Carlsson, P., Gnerback, S., Wikstrom, M. 2000. Solution structure and dynamics of the DNA-binding domain of the adipocyte-transcription factor FREAC-II. J.Mol. Biol. 296: 351-359.

Veraska, A., Del Campo, M., McGinnis, W. 2000. Developmental Patterning Genes and Their Conserved Function From Model Organisms to Humans. Molecular Genetics and Metabolism 69: $85-100$.

Wolpert, L., Beddington, R., Brockes, J., Jessell, T., Lawrence, P., Meyerowitz, E. Princípios de Biologia do Desenvolvimento. 1 ed. Porto Alegre, RS: Editora ARTMED. 2000. 576p.

Zhang, J. X., Sun, L., Zhang, Y. H. 2010. Foxn1 Gene Knockout Supresses Sexual Attractiveness and Pheromonal Components of Male Urine in Inbred Mice. Chem. Sensen. 35(47): $47-56$. 


\section{ANEXOS}

\subsection{Anexo 1}

Sequência nucleotídica do domínio forkhead de M. musculus.

Sequência de bases nitrogenadas referentes ao domínio de ligação ao DNA de FoxN1 em M. musculus de acordo com o artigo Nehls et al. (1994): N'terminalAGC.CCA.TCT.ACT.CTT.ACA.GCA.TCC.TCA.TCT.TCA.TGG.CCC.TTA.AGA.ACA.GT A.AGA.CCG.GAA.GCC.TTC.CAG.TCA.GTG.AAA.TCT.ACA.ATT.TCA.TGA.CGG.AGC .ACT.TCC.CTT.ACT.TCA.AGA.CTG.CTC.CTG.ATG.GCT.GGA.AGA.ATT.CTG.TTC.G CC.ATA.ACC.TGT.CCC.TCA.ACA.AGT.GCT.TTG.AGA.AGG.TGG.AGA.ATA.AAT.CC G.GAA.GTT.CCT.CTC.GAA.AGG.GCT.GTC.TGT.GGG.CCC.TCA.ATC.CTT.CCA.AAA. TCG.ACA.AGA.TGC.AGG.AAG.AAC.CTG.CAG.AA -C’terminal.

Sequência de aminoácidos referentes ao domínio de ligação ao DNA de FoxN1 em Mus musculus de acordo com o artigo Nehls et al. (1994): N'terminal KPIYSYSILIFMALKNSKTGSLPVSEIYNFMTEHFPYFKTAPDGWKNSVRHNLSLNKCF EKVENKSGSSSRKGCLWALNPSKIDKMQEELQK - C'terminal. 


\subsection{Anexo 2}

Certificados com parecer aprovado pelo CEUA-UnB.

Certificados do projeto com parecer aprovado pelo Comitê de Ética de Uso Animal, CEUA-UnB. Declaração referente ao projeto de mestrado e, abaixo deste, a declaração referente ao adendo feito ao projeto.

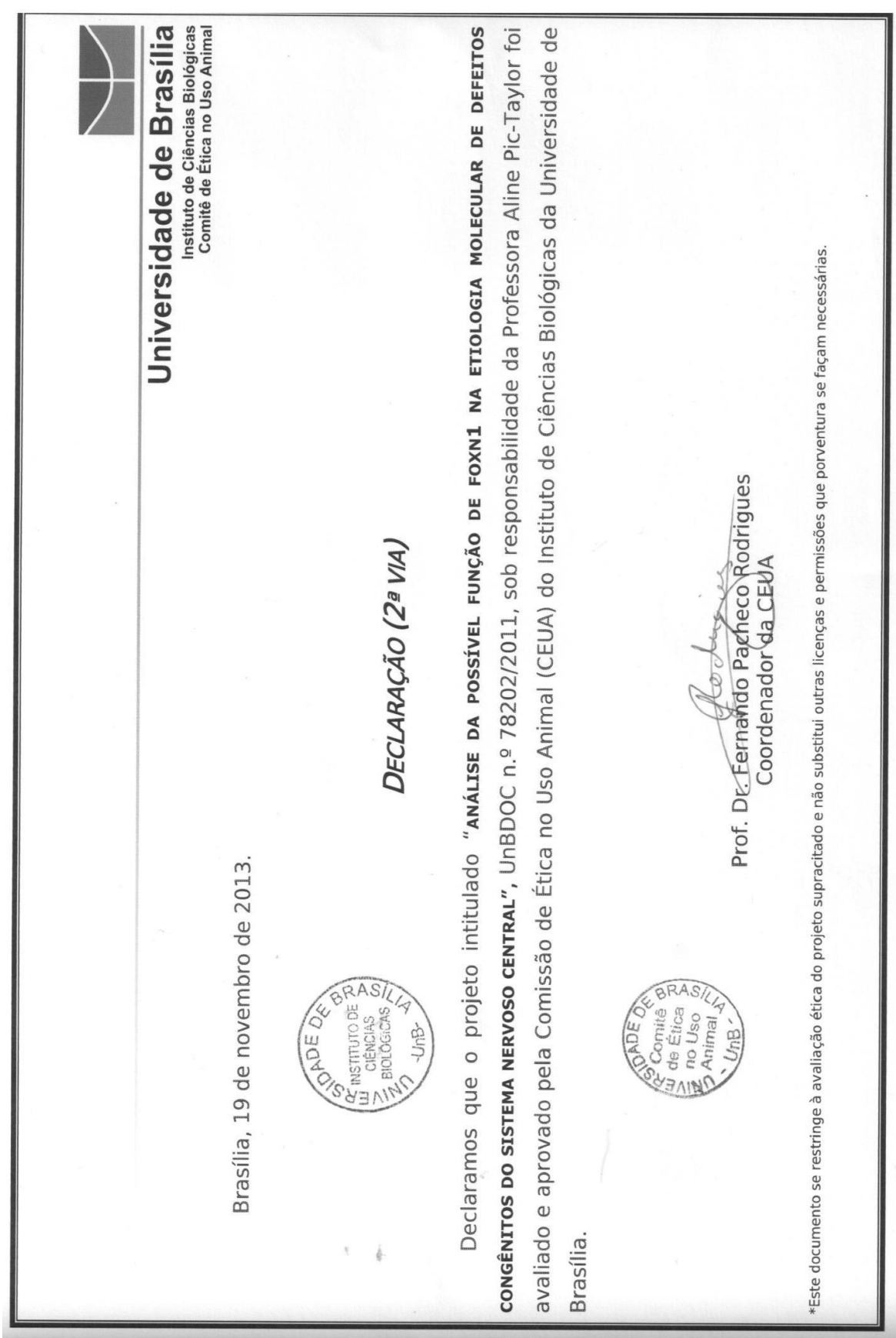




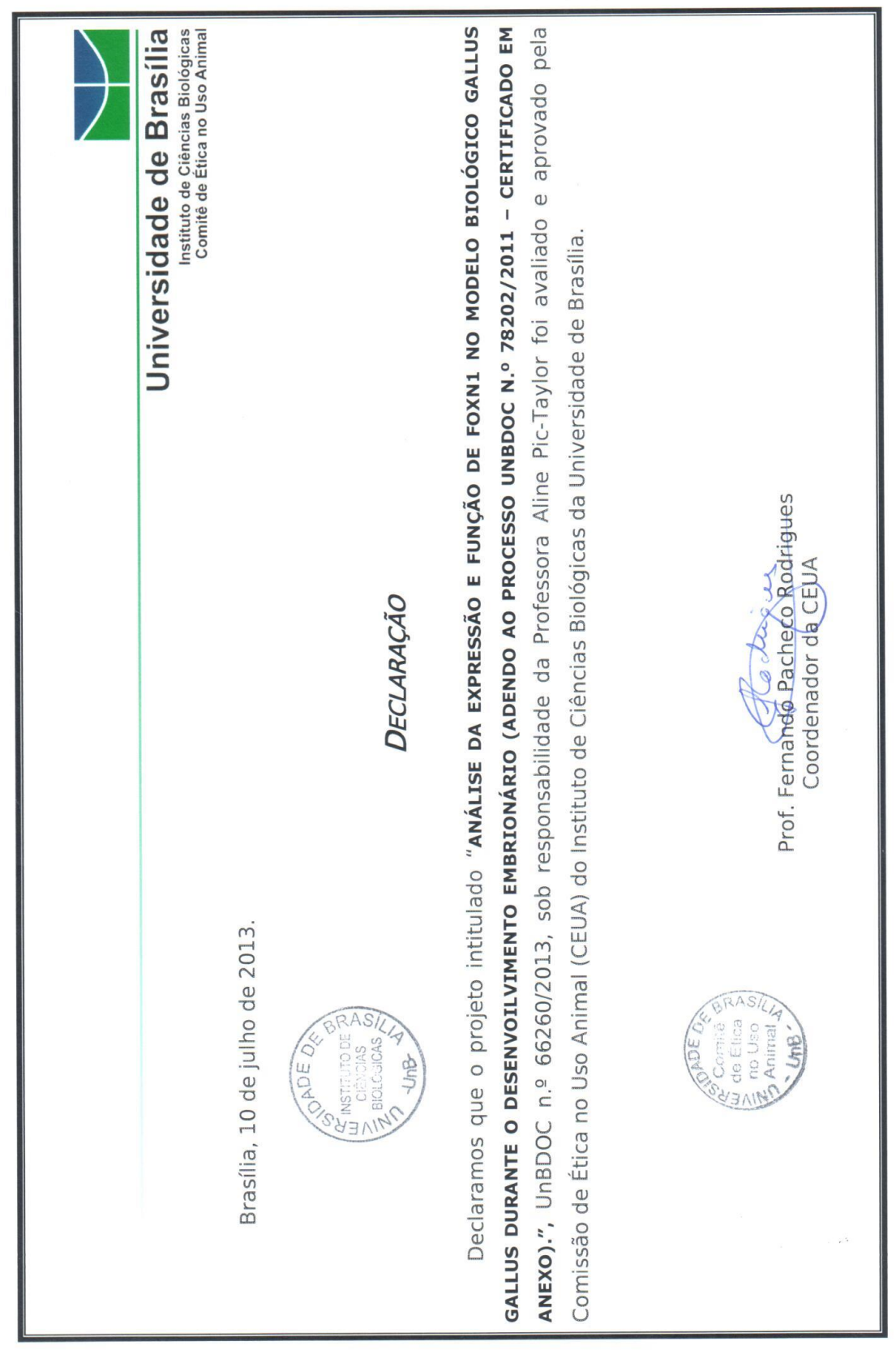




\subsection{Anexo 3}

Termo de consentimento livre e esclarecido assinado pelos responsáveis legais do paciente.

\section{Termo de consentimento livre e esclarecido}

Titulo do projeto:

Você esta sendo convidado (a) a participar do projeto acima citado. O presente convite coetetm informacoles sobre pesquisa que estamos fazendo. Sua colaboraça neste estudo serà de grande importaincia. Para a realizaclo da pesquisa ser. necessária a retirada de 4 a $8 \mathrm{ml}$. de sangue de uma das veias do antehraço do paciente e seus genitores parn exame feith rotineiramente no laboratório. Este procedimento de coleta de sangue sera realizado por pessoa qualificada e de risco minimo para a saúde podendo, entretanto, provocar pequeno desconforto. Resultando o teste positivo, será garantido um relatóribs explicativo sobre esta condiçăo.

A Professora Doutora

é a pesquisadora responsivel pelos procedimentos envolvidos, bem como da utilizaçăo dos dados produzidos durante a realizaçào desta pesquisa. A identidade do paciente serà mantida em segredo absoluto no caso de qualquer forma de divulgaçăo desta pesquisa.

A recusa em participar da presente pesquisa náo resultará em qualquer prejuizo presente ou futuro na prestacto de assistência profissional pela equipe do Serviço de Genetica Clinica do HUB, ficando também ressaltado que, mesemo após a assinatura do presente termo de consentimento, poderá abandonar a pesquisa a qualquer momento.

Os exames e coleta de sangue para análise só serào realizados se houver concordancia em participar deste estudo. Pars tal, pedimos gentilmente que o paciente ou seu responsível assine o presente documento que será entregue em duas viax, uma pura o paciente e outra que será mantida no Laboratório de Genética Clínica da Faculdade de Medicina - UNB. Participando desta pesquisa, estará ajudando no diagnóstico, aconselhamento genético e melhor entendimemto das causas de doencas genéticas. Eu, profissalo

residente e domiciliado $\mathrm{em}$ portador da Cedula de Identidade, RG e inscrito no $\mathrm{CPF} / \mathrm{MF}$ nascidor(a) em abaixo assinado(a), concordo de livre espontånea vontade com a participacta de meu (minha) filho(a) no estudo * ", e afirmo que obtive todas as informaçöes que considero necesstrias.

Caso tenham sido tiradas fotografias:

( ) Concordo que sejam incluidas em publicaçōes cientificas, se necessário.

( ) Concordo que sejam apresentadas $\mathrm{cm}$ aulas para profissionais da saúde.

( ) Nào concordo que sejam incluidas em qualquer tipo de publicaçào ou apresentaçăo.

Brasilia. de de 20

Assanatura do participante

Dra.

Pesquisadora responsdvel

Telefone para contato: (61) 31071745 